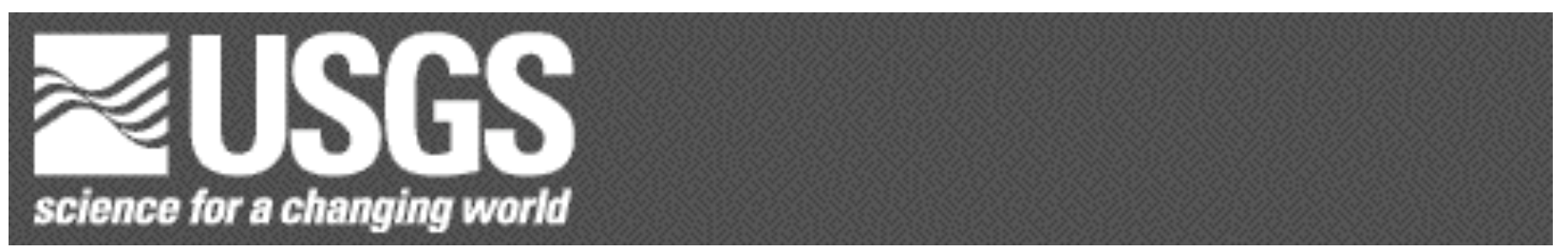

\title{
Catalog of Earthquake Hypocenters at Alaskan Volcanoes: January 1 through December 31, 2004
}

By James P. Dixon, ${ }^{1}$ Scott D. Stihler, ${ }^{2}$ John A. Power, ${ }^{3}$ Guy Tytgat, ${ }^{2}$ Steve Estes, ${ }^{2}$ Stephanie Prejean, ${ }^{3}$ John J. Sánchez, ${ }^{2}$ Rebecca Sanches, ${ }^{2}$ Stephen R. McNutt, ${ }^{2}$ and John Paskievitch ${ }^{3}$

Open-File Report 2005-1312

2005

Any use of trade, firm, or product names is for descriptive purposes only and does not imply endorsement by the U.S. Government.

\section{U.S. DEPARTMENT OF THE INTERIOR \\ U.S. GEOLOGICAL SURVEY}

${ }^{1}$ U. S. Geological Survey - Alaska Science Center, 903 Koyukuk Drive, Fairbanks, AK 99775-7320

${ }^{2}$ University of Alaska Fairbanks - Geophysical Institute, 903 Koyukuk Drive, Fairbanks, AK 99775-7320

${ }^{3}$ U. S. Geological Survey - Alaska Science Center, 4200 University Drive, Anchorage, AK 99508-4667 


\section{CONTENTS}

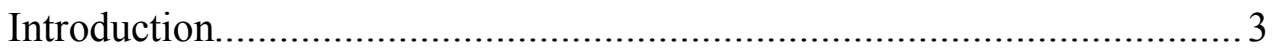

Instrumentation ............................................................................. 5

Data Acquisition and Reduction ................................................ 9

Velocity Models ..................................................................... 11

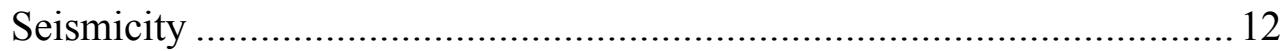

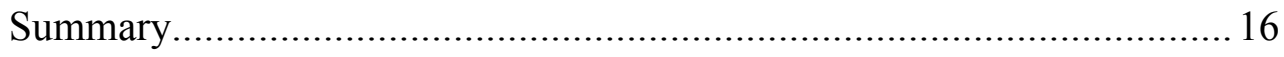

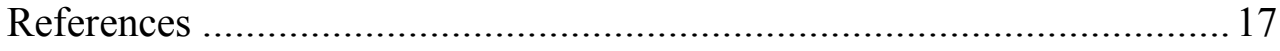

Appendix A: Maps of the earthquakes located in 2004 ........................ 20

Appendix B: Parameters for all AVO seismograph stations ................... 46

Appendix C: Maps of permanent AVO seismograph stations.................. 51

Appendix D: Station operational status......................................... 64

Appendix E: Velocity models.................................................... 68

Appendix F: Maps showing volcanic zones modeled using cylinders ..... 71

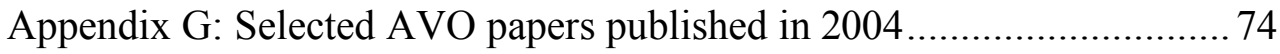




\section{Introduction}

The Alaska Volcano Observatory (AVO), a cooperative program of the U.S. Geological Survey, the Geophysical Institute of the University of Alaska Fairbanks, and the Alaska Division of Geological and Geophysical Surveys, has maintained seismic monitoring networks at historically active volcanoes in Alaska since 1988 (Power and others, 1993; Jolly and others, 1996; Jolly and others, 2001; Dixon and others, 2002; Dixon and others, 2003, Dixon and others, 2004). The primary objectives of the seismic program are the real-time seismic monitoring of active, potentially hazardous, Alaskan volcanoes and the investigation of seismic processes associated with active volcanism. This catalog presents the calculated earthquake hypocenter and phase arrival data, and changes in the seismic monitoring program for the period January 1 through December 31, 2004.

The AVO seismograph network was used to monitor the seismic activity at twenty-eight volcanoes within Alaska in 2004 (Figure 1). These include Mount Wrangell, Mount Spurr, Redoubt Volcano, Iliamna Volcano, Augustine Volcano, Katmai volcanic cluster (Snowy Mountain, Mount Griggs, Mount Katmai, Novarupta, Trident Volcano, Mount Mageik, Mount Martin), Mount Peulik, Aniakchak Crater, Mount Veniaminof, Pavlof Volcano, Mount Dutton, Isanotski Peaks, Shishaldin Volcano, Fisher Caldera, Westdahl Peak, Akutan Peak, Makushin Volcano, Okmok Caldera, Great Sitkin Volcano, Kanaga Volcano, Tanaga Volcano, and Mount Gareloi. Over the past year, formal monitoring of Okmok, Tanaga and Gareloi were announced following an extended period of monitoring to determine the background seismicity at each volcanic center. The seismicity at Mount Peulik was still being studied at the end of 2004 and has yet to be added to the list of monitored volcanoes in the AVO weekly update. AVO located 6928 earthquakes in 2004 (Table 1).

Monitoring highlights in 2004 include: (1) an earthquake swarm at Westdahl Peak in January; (2) an increase in seismicity at Mount Spurr starting in February continuing through the end of the year into 2005; (4) low-level tremor, and low-frequency events related to intermittent ash and steam emissions at Mount Veniaminof between April and October; (4) low-level tremor at Shishaldin Volcano between April and October; (5) an earthquake swarm at Akutan in July; and (6) low-level tremor at Okmok Caldera 
throughout the year (Table 2). Instrumentation and data acquisition highlights in 2004 were the installation of subnetworks on Mount Peulik and Korovin Volcano and the installation of broadband stations to augment the Katmai and Spurr subnetworks.

This catalog includes: (1) a description of instruments deployed in the field and their locations; (2) a description of earthquake detection, recording, analysis, and data archival systems; (3) a description of velocity models used for earthquake locations; (4) a summary of earthquakes located in 2004; and (5) an accompanying UNIX tar-file with a summary of earthquake origin times, hypocenters, magnitudes, phase arrival times, and location quality statistics; daily station usage statistics; and all HYPOELLIPSE files used to determine the earthquake locations in 2004.

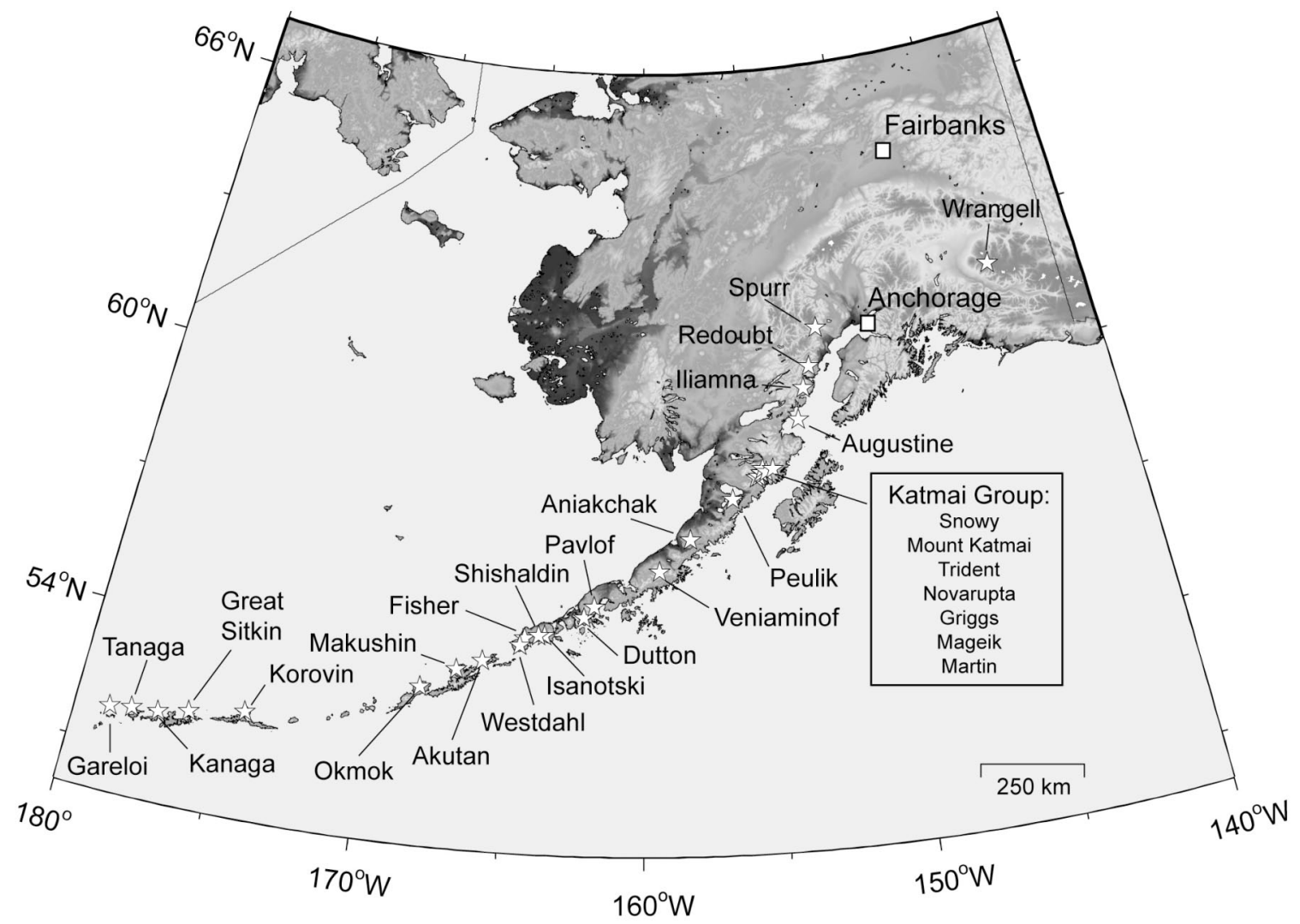

Figure 1. Stars show the location of Alaskan volcanoes seismically instrumented by AVO in 2004. Squares show the location of Anchorage and Fairbanks. 
Table 1: Number of earthquakes located per year by AVO for the last nine years.

\begin{tabular}{|c|c|c|}
\hline Year & Earthquakes located per year & Volcanoes with seismograph networks \\
\hline 1996 & 6466 & 15 \\
\hline 1997 & 2930 & 17 \\
\hline 1998 & 2873 & 19 \\
\hline 1999 & 2769 & 21 \\
\hline 2000 & 1551 & 21 \\
\hline 2001 & 1427 & 23 \\
\hline 2002 & 7242 & 24 \\
\hline 2003 & 3911 & 27 \\
\hline 2004 & 6928 & 28 \\
\hline
\end{tabular}

Table 2: Highlights of Alaskan volcanic seismicity in 2004.

\begin{tabular}{|c|c|c|}
\hline Dates & Volcano & Event \\
\hline January 2004 & Westdahl & Earthquake Swarm \\
\hline February-December 2004 & Spurr & Increased seismicity \\
\hline April-October 2004 & Veniaminof & Low-level tremor and low-frequency events \\
\hline April-October 2004 & Shishaldin & Low-level tremor \\
\hline July 2004 & Akutan & Earthquake Swarm \\
\hline January-December 2004 & Okmok & Low-level tremor \\
\hline
\end{tabular}

\section{Instrumentation}

In 2004, the AVO seismograph network was expanded from 160 to 182 permanent seismograph stations (Appendix B, C). The AVO seismograph network is composed of 21 subnetworks with 4-18 seismograph stations per subnetwork, and 14 regional seismograph stations. In August, two broadband seismograph stations were installed to augment the existing Katmai subnetwork. In response to increased activity at Mount Spurr, three broadband and two single-component short-period stations were installed in late August and early September. One broadband station was added to the Okmok subnetwork in September. Two new subnetworks were installed to monitor Mount Peulik and Korovin Volcano. The telemetry for the Peulik subnetwork was 
completed in August and the Korovin subnetwork was completed until March 2005. The 182 permanent seismograph stations have a total of 254 components.

Of the 182 permanent seismograph stations operated by AVO, 148 were shortperiod vertical-component seismograph stations. All these stations had either Mark Products L4 or Teledyne-Geotech S-13 seismometers with a one-second natural period. AVO also operated 20 three-component, short-period instruments during the catalog period. The instruments used at sites with three component sensors were Mark Products L22 seismometers with a 0.5 -second period, Mark Products L4 seismometers with a onesecond period and Teledyne-Geotech S-13 seismometers with a one-second natural period. A total of 15 broadband stations were operated with either Guralp CMG-40T seismometers (frequency range: $0.102 \mathrm{~Hz}$ to $50 \mathrm{~Hz}$ ) or Guralp CMG-6TD seismometers (frequency range: $0.033 \mathrm{~Hz}$ to $50 \mathrm{~Hz}$ ). Short-period stations are digitized at 100 samples/second and broadband stations are digitized at 50 samples/second. Typical calibration curves for seismometers used in the AVO seismograph network are shown in Figures 2-6.

Data from short-period seismograph stations were telemetered using voltagecontrolled oscillators (VCOs) to transform the ground motion signals from the seismometers to frequency-modulated signals suitable for transmission over a radio link or telephone circuit. AVO used both the A1VCO (Rogers and others, 1980) and McVCO (McChesney, 1999) to modulate signals in the field. The vast majority of seismograph stations used the McVCO since all A1VCO's are currently being phased out. These signals were transmitted via UHF and VHF radio to communication hubs located in Adak, Akutan, Anchorage, Cold Bay, Dutch Harbor, Homer, Kasilof, King Cove, King Salmon, Port Heiden, Sourdough, Sterling, and Tolsona. At the Adak, Dutch Harbor, Homer and King Salmon communication hubs, the data were digitized at the hub and then directed to AVO offices via high speed digital circuits. From all other hubs, signals were relayed via leased telephone circuits to AVO offices in Anchorage and Fairbanks where the signals were digitized. Data from broadband seismograph stations were digitized at the seismograph station site and transmitted digitally using spread-spectrum radios to communication hubs in Akutan, Anchorage, Dutch Harbor, Homer, and King 


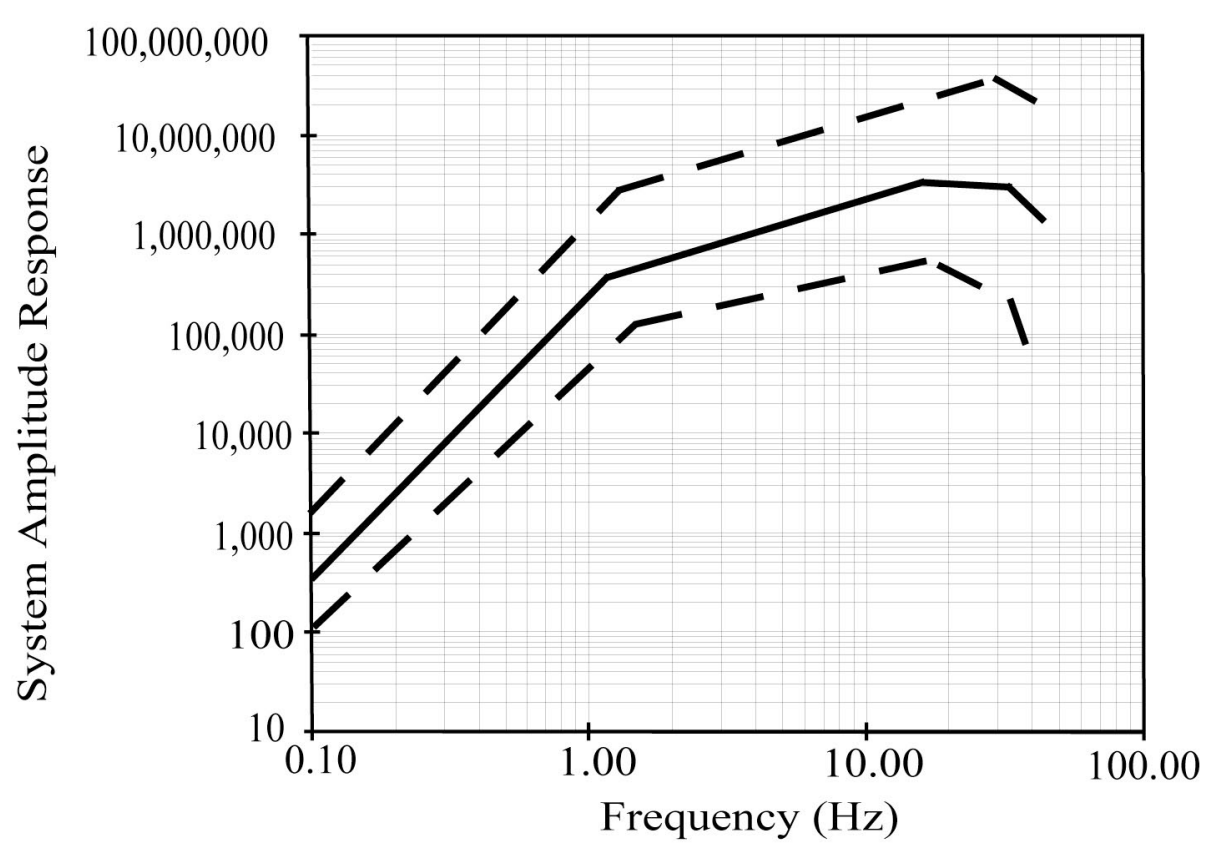

Figure 2. Representative displacement response curves for the 136 stations using a Mark Products L4 seismometer. The solid line illustrates the typical calibration curve and the dashed lines show the range of calibration curves for all AVO stations using an L4 seismometer.

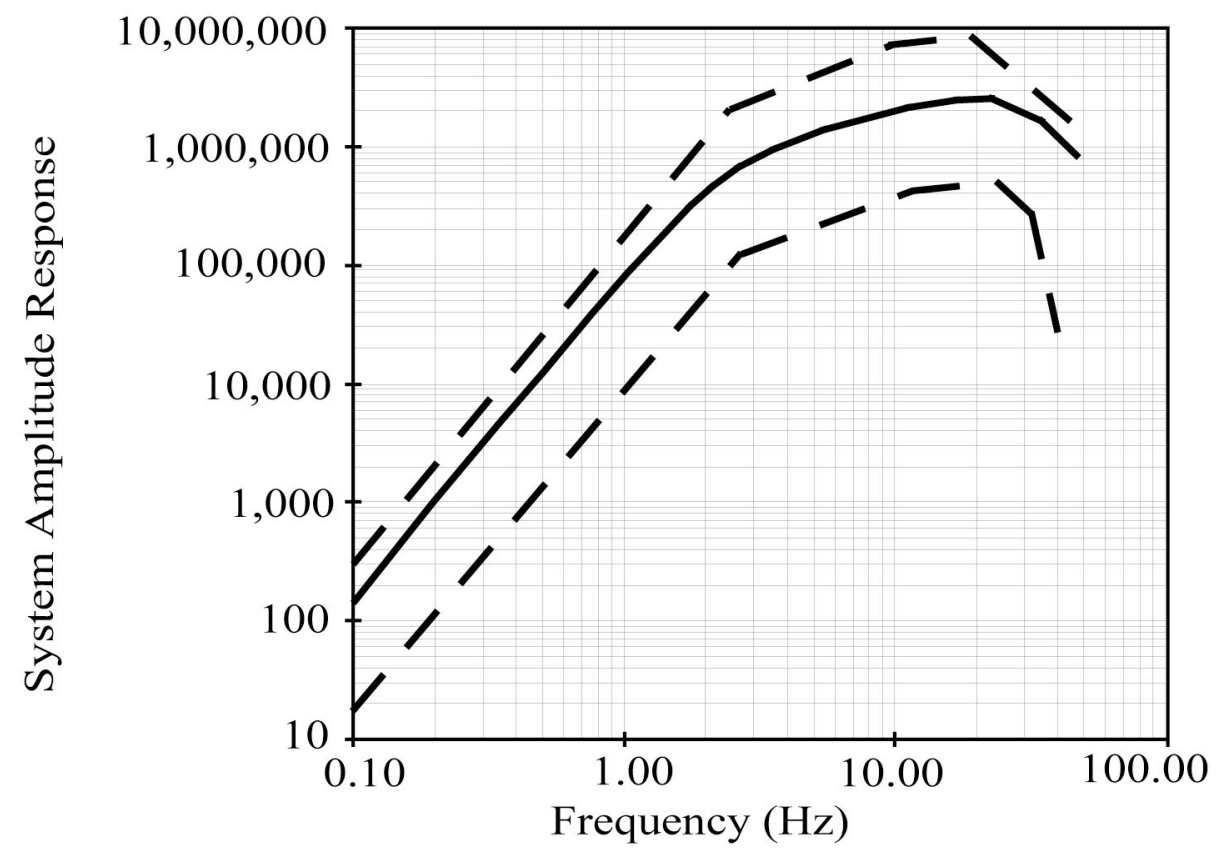

Figure 3. Representative displacement response curves for the 16 stations using a Mark Products L22 seismometer. The solid line illustrates the typical calibration curve and the dashed lines show the range of calibration curves for all AVO stations using an L22 seismometer. 


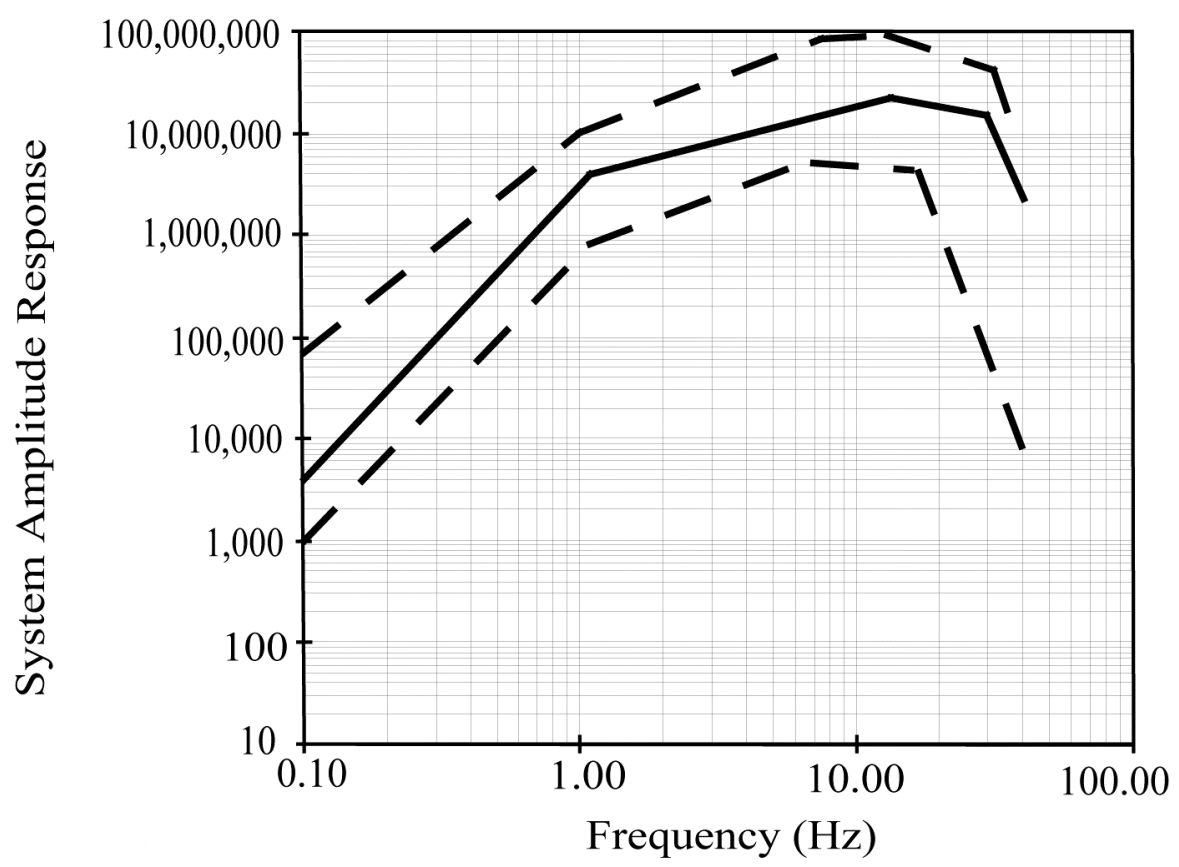

Figure 4. Representative displacement response curves for the 17 stations using a Teledyne-Geotech S-13 seismometer. The solid line illustrates the typical calibration curve and the dashed lines show the range of calibration curves for all AVO stations using an $\mathrm{S}-13$ seismometer.

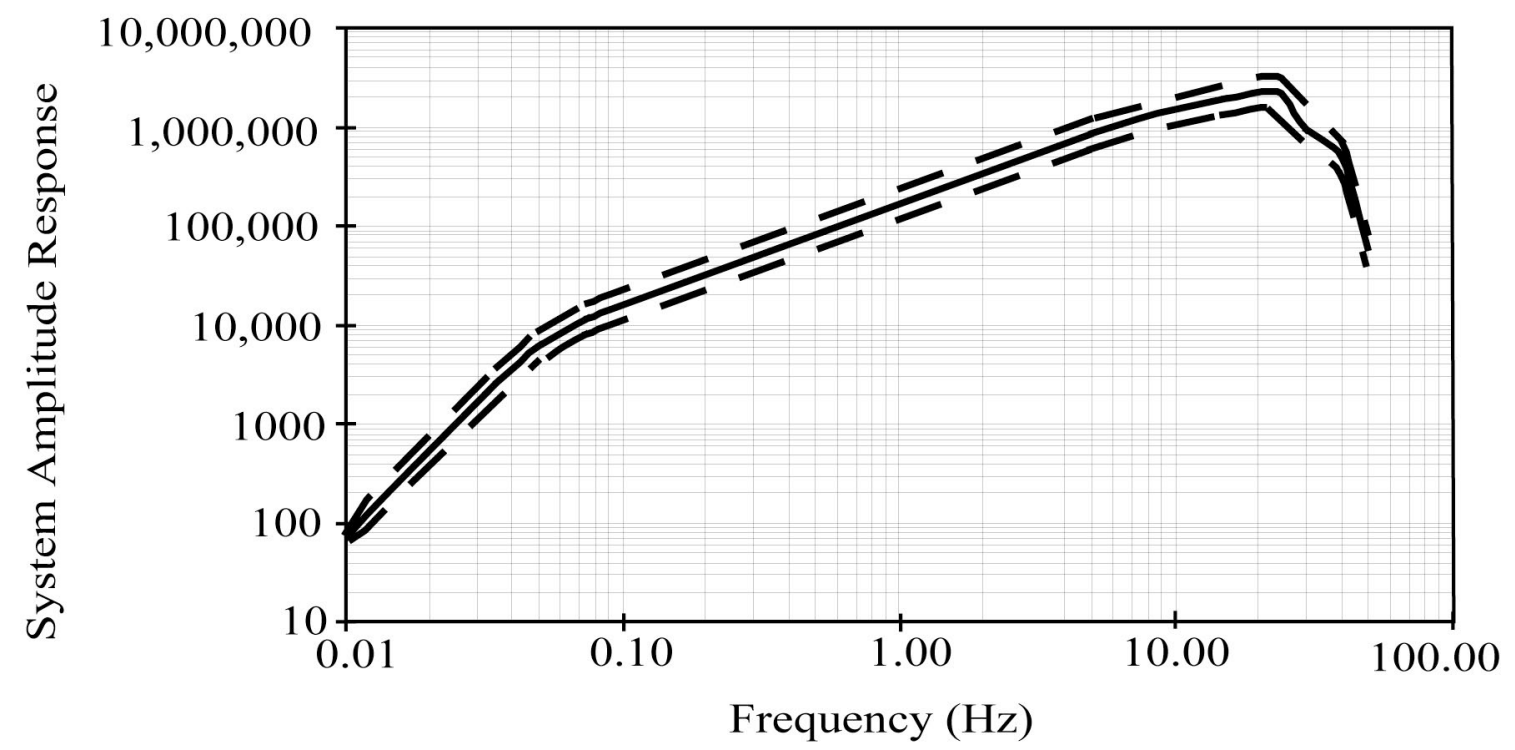

Figure 5. Representative displacement response curves for the two stations using a Guralp CMG-40T seismometer. The solid line illustrates the typical calibration curve and the dashed lines show the range of calibration curves for all AVO stations using a Guralp CMG-40T seismometer. 


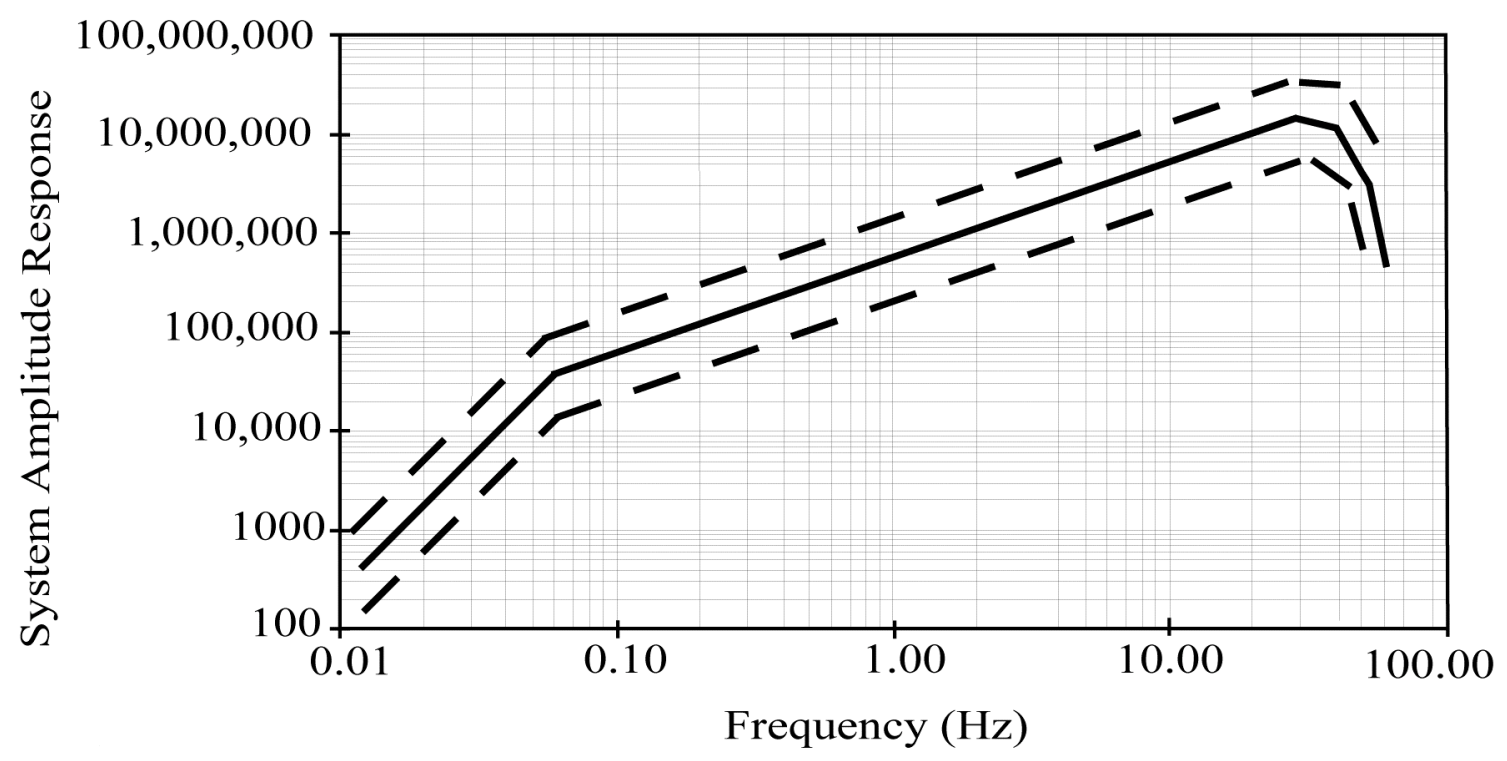

Figure 6. Representative displacement response curves for the 13 stations using a Guralp CMG-6TD seismometer. The solid line illustrates the typical calibration curve and the dashed lines show the range of calibration curves for all AVO stations using a Guralp CMG-6TD seismometer.

Salmon. The data were forwarded to AVO offices in Fairbanks and Anchorage via leased telephone circuits.

Locations and descriptions for all AVO stations operated during 2004 are contained in Appendix B. Maps showing the locations of stations with respect to individual volcanoes are contained in Appendix C. Estimates of each station's operational status for the catalog period are shown in Appendix D. Other station information, such as calibration information contained in the file CALDATA.PRM, is available within the associated compressed UNIX tar-file.

\section{Data Acquisition and Reduction}

Data acquisition for the AVO seismograph network was accomplished with duplicate EARTHWORM systems (Johnson, 1995) located at AVO offices in Anchorage and Fairbanks, providing a backup in case of failure at either location. Data were recorded in continuous and event detected modes. Event detected data were collected using the EARTHWORM modules, Carlstatrig and Carlsubtrig. The Carlstatrig 
parameters were set as follows: LTA time $=8$ seconds, Ratio $=2.3$, and Quiet $=4$.

Carlsubtrig was modified such that a two-letter code was appended to the filename of each trigger to identify which subnetwork triggered or if the event was a regional trigger. If four or more subnetworks triggered on the same event, all data were saved in a single trigger. These network codes are summarized in Table 3. All data are saved in SAC format.

Table 3: Volcano Subnetwork Designators

\begin{tabular}{|c|c|}
\hline Volcano Subnetwork & Network Code \\
\hline Akutan Peak & $\mathrm{ak}$ \\
\hline Aniakchak Crater & $\mathrm{an}$ \\
\hline Augustine Volcano & $\mathrm{au}$ \\
\hline Mount Dutton & $\mathrm{dt}$ \\
\hline Iliamna Volcano & $\mathrm{il}$ \\
\hline Mount Gareloi & $\mathrm{ga}$ \\
\hline Great Sitkin Volcano & $\mathrm{gs}$ \\
\hline Kanaga Volcano & $\mathrm{ki}$ \\
\hline Katmai Volcanic Cluster & $\mathrm{ka}$ \\
\hline Korovin Volcano & $\mathrm{ko}$ \\
\hline Makushin Volcano & $\mathrm{ma}$ \\
\hline Okmok Caldera & $\mathrm{ok}$ \\
\hline Pavlof Volcano & $\mathrm{pv}$ \\
\hline Mount Peulik & $\mathrm{pl}$ \\
\hline Redoubt Volcano & rd \\
\hline Regional event & rg \\
\hline Shishaldin Volcano & sh \\
\hline Mount Spurr & sp \\
\hline Tanaga Volcano & ta \\
\hline Mount Veniaminof & vn \\
\hline Westdahl Peak & we \\
\hline Mount Wrangell & wa \\
\hline
\end{tabular}

Event triggers were processed daily using the interactive seismic data analysis program XPICK (Robinson, 1990), and the earthquake location program HYPOELLIPSE (Lahr, 1999). Each event trigger was visually inspected and false triggers were deleted. Each subsequent event was identified by a classification code (Table 4) stored in the event location pick file. This classification system was modeled after that described by 
Lahr and others (1994). Earthquakes with a P-wave and S-wave separation of greater than five seconds on the closest station were assumed to come from non-volcanic sources and were typically discarded. The quality of each hypocenter was checked using a computer algorithm that identified events without magnitude, with fewer than three Pphases, with less than two S-phases, and with standard hypocentral errors greater than 15 $\mathrm{km}$. Events not meeting these requirements after further evaluation were removed from the final catalog listing. For all the 2004 earthquakes in the AVO catalog, the average root-mean-square travel-time error was 0.128 seconds.

Table 4: Classification codes

\begin{tabular}{|c|c|}
\hline Event Classification & Classification Code \\
\hline Volcano-Tectonic (VT) & $\mathrm{a}$ \\
\hline Low-Frequency (LF) & $\mathrm{b}$ \\
\hline Hybrid & $\mathrm{h}$ \\
\hline Regional-Tectonic & $\mathrm{E}$ \\
\hline Teleseismic & $\mathrm{T}$ \\
\hline Shore-Ice & $\mathrm{i}$ \\
\hline Calibrations & $\mathrm{C}$ \\
\hline Other non-seismic & $\mathrm{o}$ \\
\hline Cause unknown & $\mathrm{x}$ \\
\hline
\end{tabular}

\section{Velocity Models}

During 2004, AVO employed eight local velocity models and one regional seismic velocity model (Appendix E) to locate earthquakes at monitored volcanoes in 2004. All velocity models were one-dimensional models utilizing horizontal layers to approximate the local seismic velocity structures. Each model, with one exception, assumed a series of constant velocity layers. The single exception was the Akutan velocity model (Power and others, 1996), which had a velocity gradient in the top layer overlying a half-space of constant velocity.

One or more vertical cylinders were used to model the volcanic source zones on all volcanoes where a local volcano-specific velocity model was used. Earthquakes within these cylindrical volumes were located with a local model and earthquakes outside of the cylindrical volumes were located with the regional model. All cylindrical volumes 
had a radius of $20 \mathrm{~km}$ with the exception of the cylinder centered on Shishaldin Volcano. The cylinder centered on Shishaldin Volcano had a radius of $30 \mathrm{~km}$ in order to encompass Isanotski Peaks. The top of each cylinder is set at three $\mathrm{km}$ above sea level and the bottom is set at a depth of $50 \mathrm{~km}$ with respect to sea level.

The Akutan, Augustine (Power, 1988), and Iliamna (Roman and others, 2001) velocity models were used to locate hypocenters that fell within cylindrical volumes described above, centered on each respective volcano. The Cold Bay velocity model (McNutt and Jacob, 1986) was used to locate earthquakes that fell within single cylindrical volumes centered on Mount Dutton and Pavlof Volcano. Earthquakes on Fisher Caldera, Isanotski Peaks, Shishaldin Volcano, and Westdahl Peak that fell within the cylindrical regions centered on Shishaldin Volcano and Westdahl Peak were also located with the Cold Bay velocity model. Five overlapping cylinders defined the area in which the Spurr velocity model (Jolly and others, 1994) was used, four overlapping cylinders defined the area in which the Redoubt velocity model (Lahr and others, 1994) was used, and four overlapping cylinders defined the area in which the Katmai model (Searcy, 2003) was used. The Andreanof velocity model (Toth and Kisslinger, 1984) was used to locate earthquakes within a volume defined by three cylinders centered on Kanaga Volcano, Mount Moffet, and Great Sitkin Volcano. Specific velocity models for Aniakchak Crater, Mount Gareloi, Korovin Volcano, Makushin Volcano, Okmok Volcano, Mount Peulik, Tanaga Volcano, Mount Veniaminof, and Mount Wrangell were not available in 2004 and the regional velocity model (Fogleman and others, 1993) was used to locate earthquakes surrounding these volcanoes. The cylindrical model parameters, regional velocity model, and volcano-specific models used to locate earthquakes in this report are summarized in Appendix E. Figures showing the volcanic source zones modeled by cylinders in map view are shown in Appendix F.

\section{Seismicity}

The 6928 earthquakes located in 2004 represent the third highest annual total determined by AVO in a single calendar year since recording began in 1989 and an increase from the 3911 earthquakes located in 2003. Of the earthquakes located in 2004, 5326 were classified as volcano-tectonic earthquakes, 1411 are classified as low- 
frequency earthquakes and 191 are classified in other categories listed in Table 4. Of the earthquakes located in 2003 and 2004, a total of 3264 earthquakes in 2003 and 6105 earthquakes in 2004 were located within $20 \mathrm{~km}$ of an active volcanic center. The number of located events in the last two years, by seismograph subnetwork, is shown in Table 5.

Using the 2004 earthquake catalog, the magnitude of completeness (Mc) for each subnetwork was calculated (Table 6). The Mc, calculated using ZMAP (Weimer, 2001), is the lowest magnitude at which we are reasonably certain that all events of greater magnitude were detected. The Mc was determined automatically using a maximum likelihood estimate of the inflection point in the frequency magnitude distribution. Earthquakes from previous years were included to calculate the Mc for the Aniakchak.

Table 5: Number of earthquakes located for each seismograph subnetwork in 2003 and 2004 within $20 \mathrm{~km}$ of the volcanic centers in each subnetwork. The totals for 2004 are broken into three event types: volcanic-tectonic (VT), low-frequency (LF) and other (all possible event types are shown in Table 3).

\begin{tabular}{|c|c|c|c|c|c|}
\hline $\begin{array}{c}\text { Volcano } \\
\text { Subnetwork }\end{array}$ & $\begin{array}{c}\text { Earthquakes } \\
\text { located in 2003 }\end{array}$ & $\begin{array}{c}\text { Earthquakes } \\
\text { located in 2004 }\end{array}$ & $\begin{array}{c}\mathbf{2 0 0 4} \\
\text { VT }\end{array}$ & $\begin{array}{c}\mathbf{2 0 0 4} \\
\text { LF }\end{array}$ & $\begin{array}{c}\mathbf{2 0 0 4} \\
\text { Other }\end{array}$ \\
\hline Akutan Peak & 66 & 120 & 108 & 12 & 0 \\
\hline Aniakchak Crater & 11 & 5 & 2 & 3 & 0 \\
\hline Augustine Volcano & 107 & 241 & 236 & 0 & 5 \\
\hline Mount Dutton & 37 & 40 & 38 & 2 & 0 \\
\hline Mount Gareloi & 9 & 376 & 69 & 307 & 0 \\
\hline Great Sitkin Volcano & 84 & 65 & 65 & 0 & 0 \\
\hline Iliamna Volcano & 587 & 805 & 306 & 498 & 1 \\
\hline Kanaga Volcano & 22 & 32 & 30 & 2 & 0 \\
\hline Katmai Vol. Cluster & 1065 & 976 & 956 & 19 & 1 \\
\hline Makushin Volcano & 59 & 233 & 226 & 7 & 0 \\
\hline Okmok Caldera & 34 & 44 & 43 & 1 & 0 \\
\hline Pavlof Volcano & 80 & 58 & 22 & 36 & 0 \\
\hline Mount Peulik & $\mathrm{n} / \mathrm{a}$ & 5 & 5 & 0 & 0 \\
\hline Redoubt Volcano & 62 & 94 & 90 & 4 & 0 \\
\hline Shishaldin Volcano & 285 & 98 & 20 & 78 & 0 \\
\hline Mount Spurr & 549 & 2616 & 2312 & 301 & 3 \\
\hline Tanaga Volcano & 3 & 11 & 11 & 0 & 0 \\
\hline Mount Veniaminof & 38 & 21 & 20 & 1 & 0 \\
\hline Westdahl Peak & 75 & 166 & 145 & 21 & 0 \\
\hline Mount Wrangell & 91 & 99 & 11 & 88 & 0 \\
\hline Totals & 3264 & 6105 & 4715 & 1380 & 10 \\
\hline
\end{tabular}


Table 6: Magnitude of completeness (Mc) for AVO seismograph subnetworks using the 2004 Catalog. The Peulik subnetwork was not included because there were too few earthquakes to calculate a Mc.

\begin{tabular}{|c|c|}
\hline Volcano Subnetwork & Magnitude of Completeness \\
\hline Akutan Peak & 0.2 \\
\hline Aniakchak Crater & 1.7 \\
\hline Augustine Volcano & 0.0 \\
\hline Mount Dutton & 0.5 \\
\hline Mount Gareloi & 1.1 \\
\hline Great Sitkin Volcano & 0.7 \\
\hline Iliamna Volcano & -0.4 \\
\hline Kanaga Volcano & 1.2 \\
\hline Katmai Volcanic Cluster & 0.6 \\
\hline Makushin Volcano & 0.7 \\
\hline Okmok Caldera & 1.5 \\
\hline Pavlof Volcano & 0.7 \\
\hline Redoubt Volcano & 0.2 \\
\hline Shishaldin Volcano & 1.0 \\
\hline Mount Spurr & 0.2 \\
\hline Tanaga Volcano & 0.7 \\
\hline Mount Veniaminof & 1.1 \\
\hline Westdahl Peak & 0.6 \\
\hline Mount Wrangell & 0.8 \\
\hline
\end{tabular}

and Tanaga subnetworks because the sample size in 2004 was not sufficiently large to allow one to compute a Mc for these subnetworks.

The increase in the number of earthquakes located in 2004 compared to those in 2003 at the Augustine and Iliamna subnetworks were a direct result of station maintenance which corrected several station outages in the summer of 2004 . The earthquake rates in 2002 at both Augustine and Iliamna Volcanoes were comparable to the earthquakes rates in 2004. The July earthquake swarm at Akutan Volcano accounts for only half of the increase in detected seismicity. The additional increase in detected seismicity seen at Akutan Volcano was a likely result of the installation of four broadband seismometers in 2003 as the magnitude of completeness improved from 1.2 (Dixon and others, 2005) to 0.2. The networks for Gareloi and Tanaga were installed last year so a comparison between earthquakes located in 2003 and 2004 was not possible. 
The increase in seismicity at Westdahl Peak was a result of an earthquake swarm in January 2004. The Mount Spurr seismicity in 2004 was dominated by the volcanic unrest first noted in July 2004 (Power, 2004). The Mount Spurr seismicity slowly increased in February and peaked in July. From July through the end of the year, the Mount Spurr seismicity continued well above historical levels.

On Mount Veniaminof, the seismic activity was dominated by non-locatable tremor and low-frequency events. Some of these low-frequency events have been correlated to small ash and steam emissions (Sánchez, 2005). For this reason the seismicity was not adequately described by the number of located earthquakes. Long episodes of tremor also masked the ability of the data acquisition system in detecting individual earthquakes. The seismic activity at Shishaldin Volcano has continued to decline from the 2620 earthquakes located in 2002. Between April and October 2004, there were periods in which numerous low-frequency events were detected at Shishaldin Volcano but were unable to be located. The magnitude of completeness for the Shishaldin subnetwork in 2004 increased to 1.0 from a value of 0.5 (Dixon and others, 2005) although all methods of estimating rates of seismicity at the AVO indicated a decrease in activity in 2004 compared to that in 2003.

The decreases in seismicity at Pavlof and Makushin Volcanoes were related to tectonic earthquakes that occurred within $20 \mathrm{~km}$ of each volcanic center. The number of earthquakes that were located within a five $\mathrm{km}$ radius circle centered on Makushin Volcano was 27 in 2003 and 31 in 2004 . The vast majority of the seismicity increase seen in Table 5 occurred greater than $10 \mathrm{~km}$ from the summit of Makushin Volcano. A similar trend was seen for Pavlof Volcano in which 10 earthquakes were located within five $\mathrm{km}$ of Pavlof Volcano during 2004, a decrease of a single earthquake from the eleven earthquakes located in 2003.

Seismicity at the Katmai Volcanic Cluster and Great Sitkin Volcano declined compared to that in 2003 but the seismicity is not significantly different than the overall seismicity since 2002. Seismicity rates at the remaining subnetworks in 2004, Wrangell, Redoubt, Aniakchak, Dutton, Okmok, and Kanaga subnetworks, were similar to those in 2003. 


\section{Summary}

Between January 1, 2004, and December 31, 2004, AVO located 6928

earthquakes that occurred at or near volcanoes in Alaska. Monitoring highlights in 2004 include: earthquake swarms at Westdahl Peak and Akutan Volcano, elevated seismicity and low level tremor at Mount Veniaminof, Shishaldin Volcano, and Okmok Volcano, and an increase in seismicity at Mount Spurr related to an episode of volcanic unrest. New seismic subnetworks were installed on Mount Peulik and Korovin Volcano and broadband stations were installed to augment the subnetworks on Spurr, Katmai and Okmok volcanic centers.

Available for download with this report is a compressed Unix tar-file containing a summary listing of earthquake hypocenters and all the necessary HYPOELLIPSE input files to recalculate the hypocenters including station locations and calibrations, velocity models, and phase information. The reader should refer to Lahr (1999) for information on file formats and instructions for configuring and running the location program HYPOELLIPSE. Archives of waveform data are maintained on CD-ROM at AVO offices in Fairbanks and Anchorage.

\section{Acknowledgements}

The contents of this report reflect a great deal of hard work by a large number of people including AVO, AEIC, and USGS personnel and various students, interns and volunteers. We thank Peter Cervelli, Silvio DeAngelis and Mike West for formal reviews of the text and figures. 


\section{References}

Dixon, J.P, Stihler, S.D., Power J.A., Tytgat, G., Estes, S., Moran, S.C., Paskievitch, J., McNutt, S.R., 2002, Catalog of Earthquake Hypocenters at Alaska Volcanoes: January 1, 2000 - December 31, 2001: U.S. Geological Survey Open-file Report 02-342, 56p.

Dixon, J.P., Stihler, S.D., Power J.A., Tytgat, G., Moran, S.C., Sánchez, J., Estes, S., McNutt, S.R., Paskievitch, J., 2003, Catalog of Earthquake Hypocenters at Alaska Volcanoes: January 1 - December 31, 2002: U.S. Geological Survey Open-file Report 03-267, 58p.

Dixon, J.P., Stihler, S.D., Power J.A., Tytgat, G., Moran, S.C., Sánchez, J., Estes, S., McNutt, S.R., Paskievitch, J., 2004, Catalog of Earthquake Hypocenters at Alaska Volcanoes: January 1 - December 31, 2003: U.S. Geological Survey Open-file Report 2004-1234, 59p.

Dixon, J.P., Power, J.A., Stihler, S.D., 2005, A Comparison of Seismic Event Detection with IASPEI and Earthworm Acquisition Systems at Alaskan Volcanoes, Seismological Research Letters, v. 2, p. 168-176.

Fogleman, K.A., Lahr, J.C., Stephens, C.D., and Page, R.A., 1993, Earthquake locations determined by the southern Alaska seismograph network for October 1971 through May 1989: U.S. Geological Survey Open-file Report 93-309, 54p.

Johnson, C.E., Bittenbinder, A., Bogaert, B., Dietz, L., Kohler, W., 1995, EARTHWORM: A Flexible Approach to Seismograph network Processing, Incorporated Research Institutions for Seismology Newsletter, v. 14, no. 2, p. 1-4.

Jolly, A.D., Page, R.A., and Power, J.A., 1994, Seismicity and stress in the vicinity of Mt. Spurr volcano, south-central Alaska: Journal of Geophysical Research, v. 99, p. 15305-15318.

Jolly, A.D, Power, J.A., Stihler, S.D., Rao, L.N., Davidson, G., Paskievitch, J., Estes, S., Lahr, J.C., 1996, Catalog of earthquake hypocenters for Augustine, Redoubt, Iliamna, and Mount Spurr Volcanoes, Alaska: January 1, 1991 - December 31, 1993: U.S. Geological Survey Open-file Report 96-70, 90p.

Jolly, A.D., Stihler, S.D., Power, J.A., Lahr, J.C., Paskievitch, J., Tytgat, G., Estes, S., Lockhart, A.B., Moran, S.C., McNutt, S.R., Hammond, W.R., 2001, Catalog of earthquake hypocenters at Alaskan Volcanoes: January 1, 1994 - December 31, 1999: U.S. Geological Survey Open-file Report 01-189, 202p. 
Lahr, J.C, Chouet, B.A., Stephens, C.D., Power, J.A., Page, R.A., 1994, Earthquake classification, location, and error analysis in a volcanic environment: Implications for the magmatic system of the 1989-90 eruptions at Redoubt Volcano, Alaska: Journal of Volcanology and Geothermal Research, v. 62, p. 137-152.

Lahr, J.C., 1999, HYPOELLIPSE: A Computer Program for Determining Local Earthquake Hypocentral Parameters, Magnitude, and First Motion Pattern: U.S. Geological Survey Open File Report 99-23, 116p.

McChesney, P.J., 1999, McVCO Handbook 1999: U.S. Geological Survey, Open-File Report 99-361, 48p.

McNutt, S.R., and Jacob, K.H., 1986, Determination of large-scale velocity structure of the crust and upper mantle in the vicinity of Pavlof volcano, Alaska: Journal of Geophysical Research, v. 91, p. 5013-5022.

Power, J.A., 1988, Seismicity associated with the 1986 eruption of Augustine Volcano, Alaska: University of Alaska Fairbanks, Masters thesis, 149p.

Power, J.A., Paskievitch, J.F., Richter, D.H., McGimsey, R.G., Stelling, P., Jolly, A.D., Fletcher, H.J., 1996, 1996 seismicity and ground deformation at Akutan Volcano, Alaska: EOS Transactions of the American Geophysical Union, v. 77, p. F514.

Power, J.A., 2004, Renewed unrest at Mount Spurr Volcano, Alaska, EOS, v. 85, p. 434.

Power, J.A., March, G.D., Lahr, J.C., Jolly, A.D., Cruse, G.R., 1993, Catalog of earthquake hypocenters at Redoubt Volcano and Mount Spurr, Alaska: October 12, 1989December 31, 1990: U.S. Geological Survey Open-File Report, 93-685-A, 57p.

Robinson, M., 1990, XPICK users manual, version 2.7: Seismology Lab, Geophysical Institute, University of Alaska Fairbanks, 93p.

Rogers, J.A., Maslak, S., and Lahr, J.C., 1980, A seismic electronic system with automatic calibration and crystal reference: U.S. Geological Survey Open-file Report 80324, 130p.

Roman, D.C., Power, J.A., Moran, S.C., Cashman, K.V., Stihler, S.D., 2001, Unrest at Iliamna Volcano, Alaska in 1996, Evidence for a magmatic intrusion: EOS Transactions of the American Geophysical Union, v. 82, p. F1329.

Sánchez, J.J, 2005, Volcano Seismology from around the World: Case Studies from Mount Pinatubo (Philippines), Galeras (Columbia), Mount Wrangell and Mount Veniaminof (Alaska): University of Alaska Fairbanks Phd Dissertation, 208p. 
Searcy, C.K., 2003, Station Corrections for the Katmai Region Seismograph network: U.S. Geological Survey Open-file Report 03-403, 16p.

Toth, T., and Kisslinger, C., 1984, Revised focal depths and velocity model for local earthquakes in the Adak seismic zone: Bulletin of the Seismological Society of America, v. 74, p. 1349-1360.

Wiemer, S., 2001, A software package to analyze seismicity: ZMAP, Seismological Research Letters 72, 373-382. 
Appendix A: Maps showing the locations of the earthquakes located in 2004.
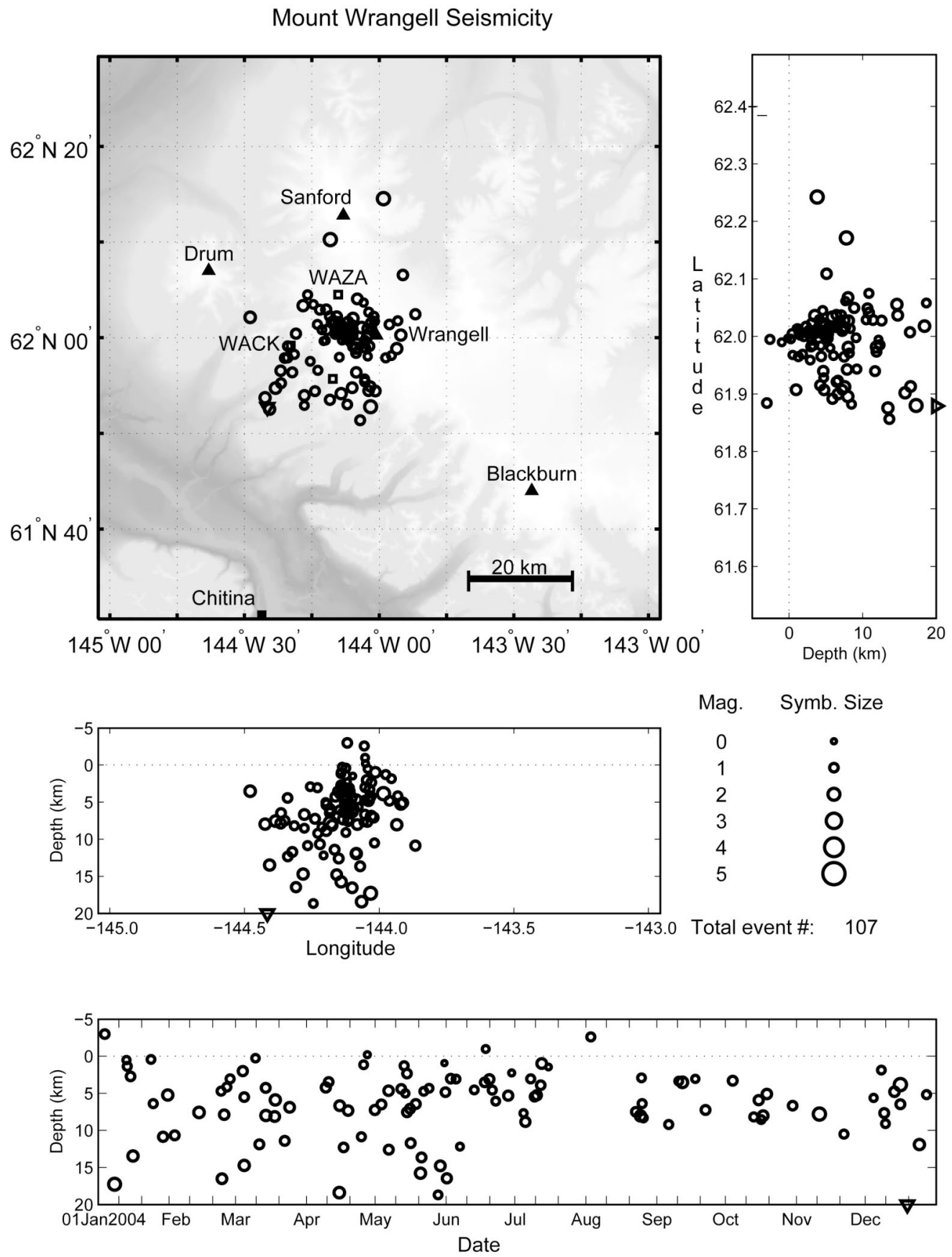

Figure A1. Summary plots of 107 earthquakes located near Mount Wrangell in 2004. Open circles show hypocenter locations shallower than $20 \mathrm{~km}$ and open triangles show hypocenters with depths of $20 \mathrm{~km}$ and deeper. Hypocenter symbols are scaled with magnitude. Seismograph stations are shown by open squares and labeled by station code. (See Appendix B for station information). Solid triangles are used to show volcanic centers and closed squares are used to show other points of interest. 
Mount Spurr Seismicity
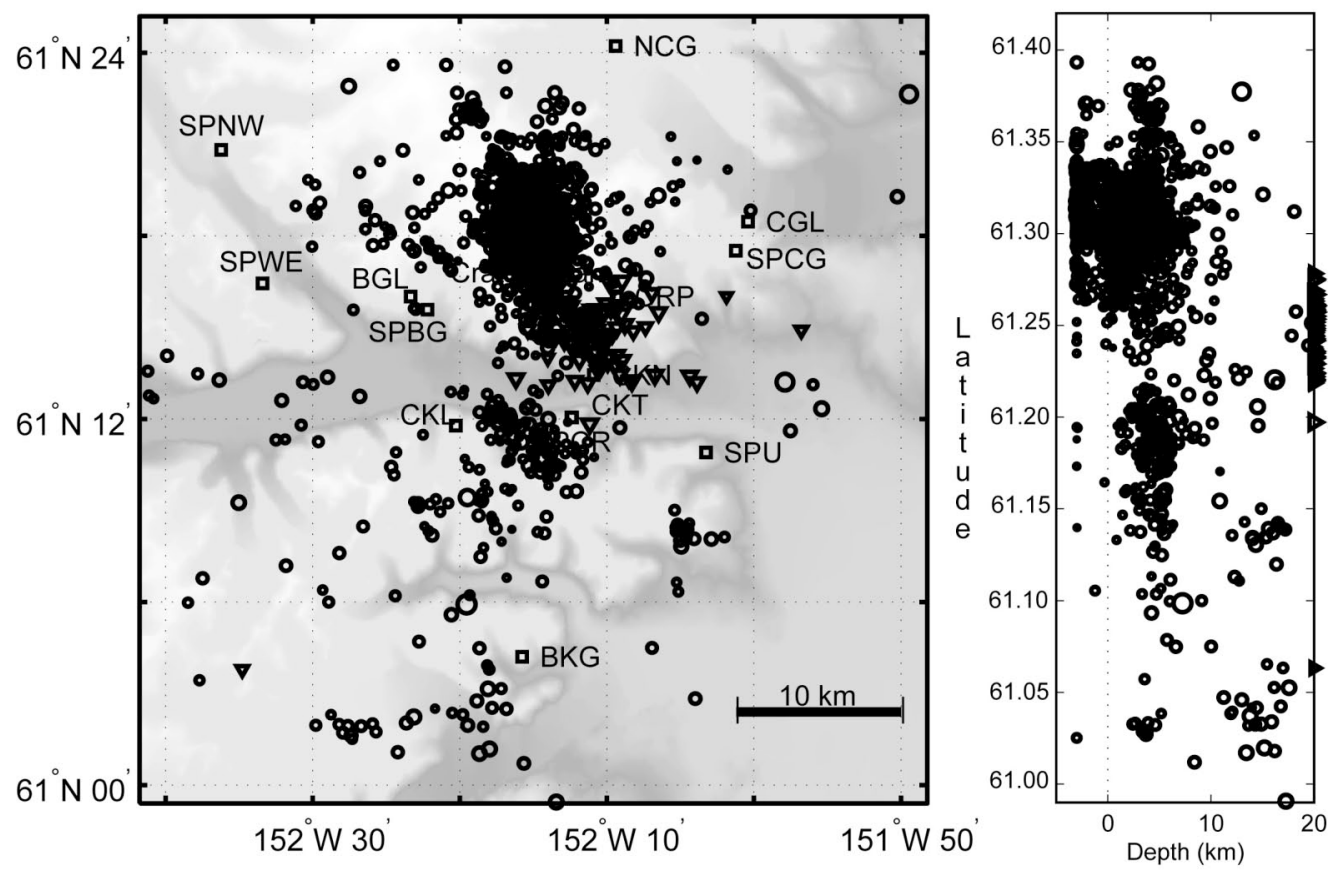

Mag. Symb. Size
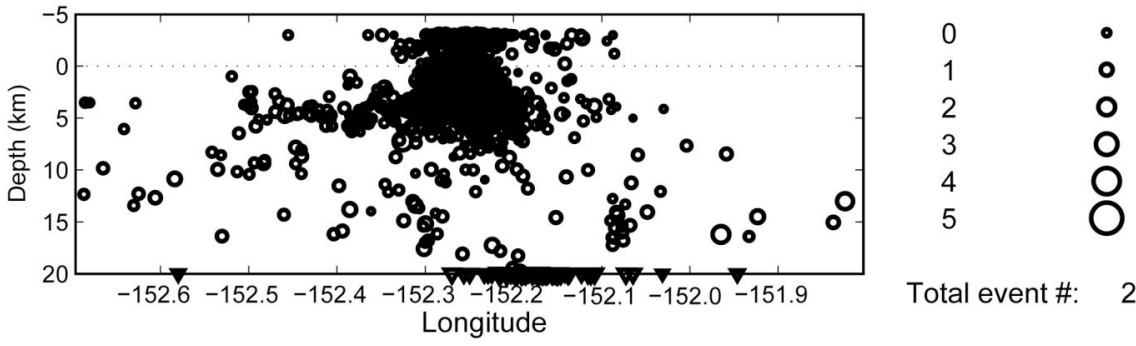

Total event \#: 2650

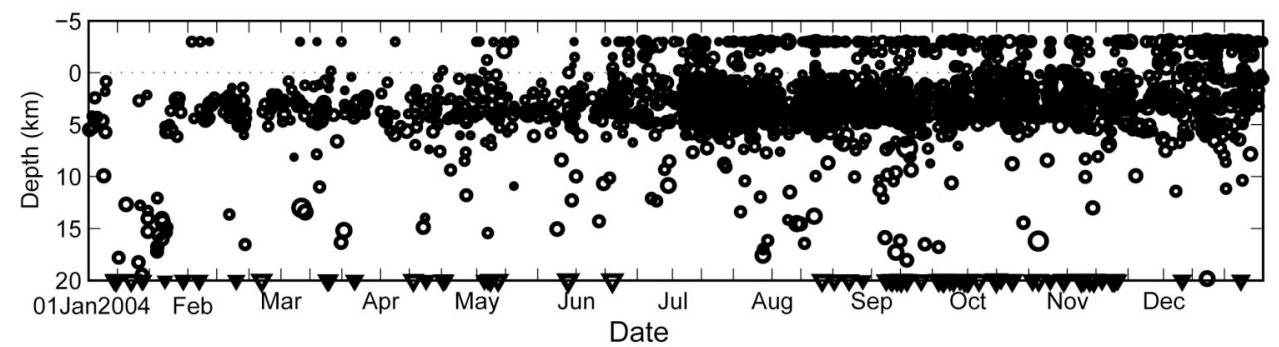

Figure A2. Summary plots of 2650 earthquakes located near Mount Spurr in 2004. Open circles show hypocenter locations shallower than $20 \mathrm{~km}$ and open triangles show hypocenters with depths of $20 \mathrm{~km}$ and deeper. Hypocenter symbols are scaled with magnitude. Seismograph stations are shown by open squares and labeled by station code. (See Appendix B for station information). Solid triangles are used to show volcanic centers and closed squares are used to show other points of interest. 
Redoubt Volcano Seismicity
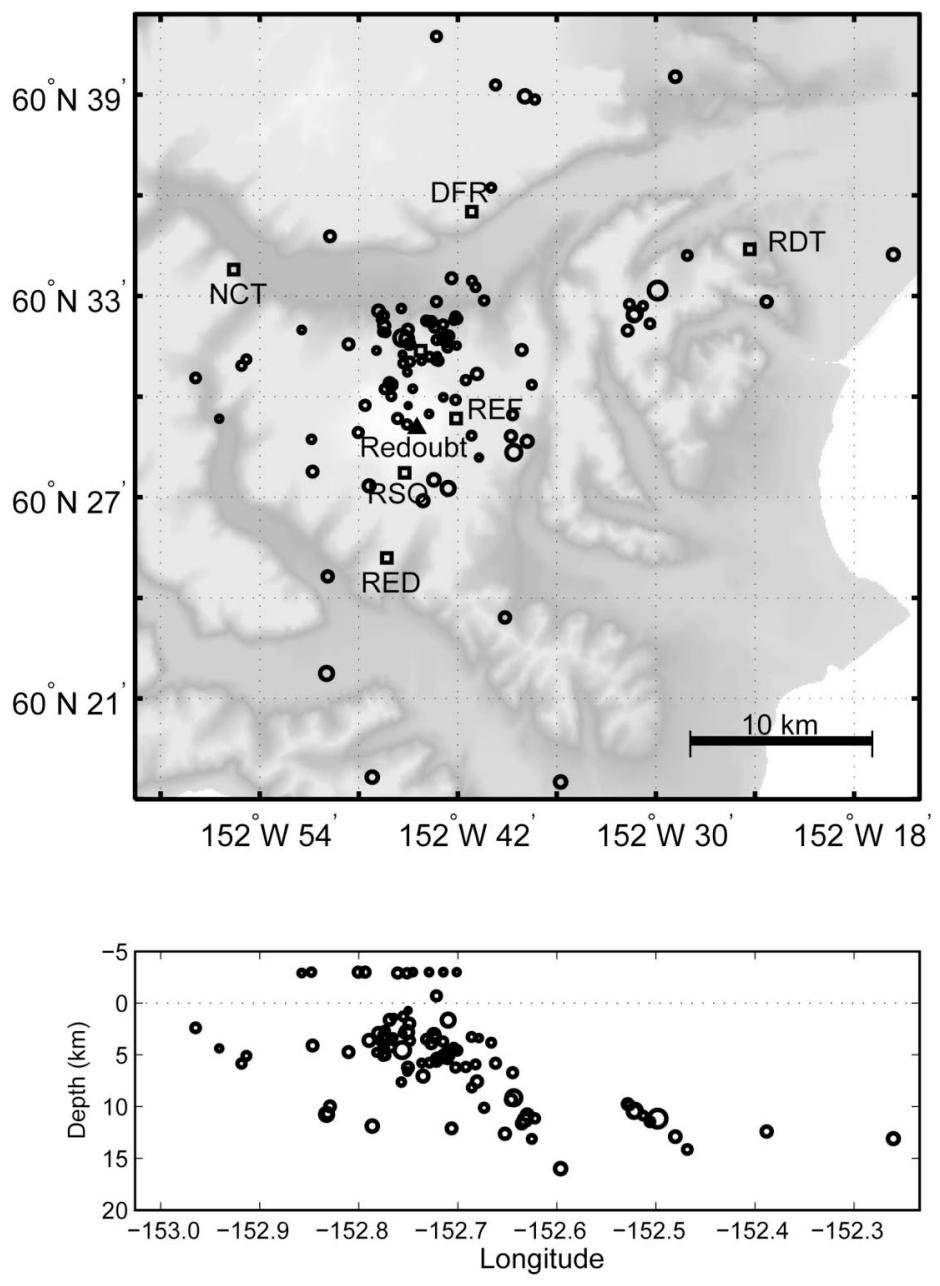

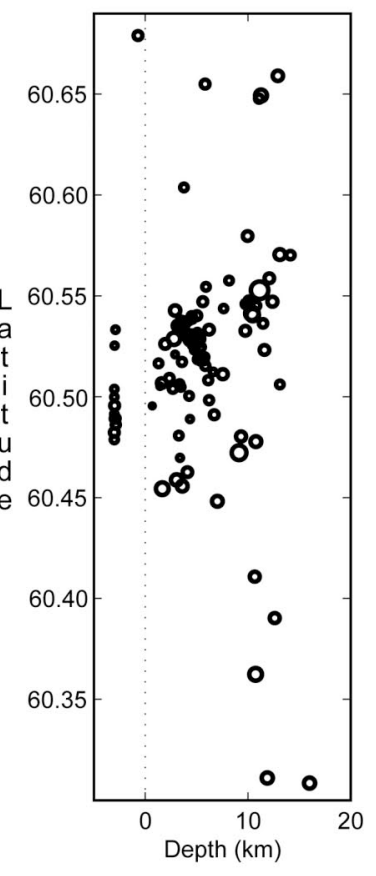

Mag. Symb. Size

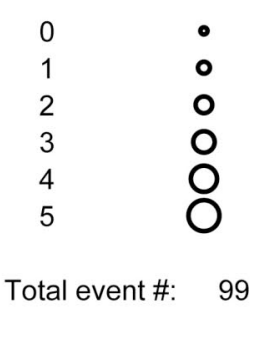

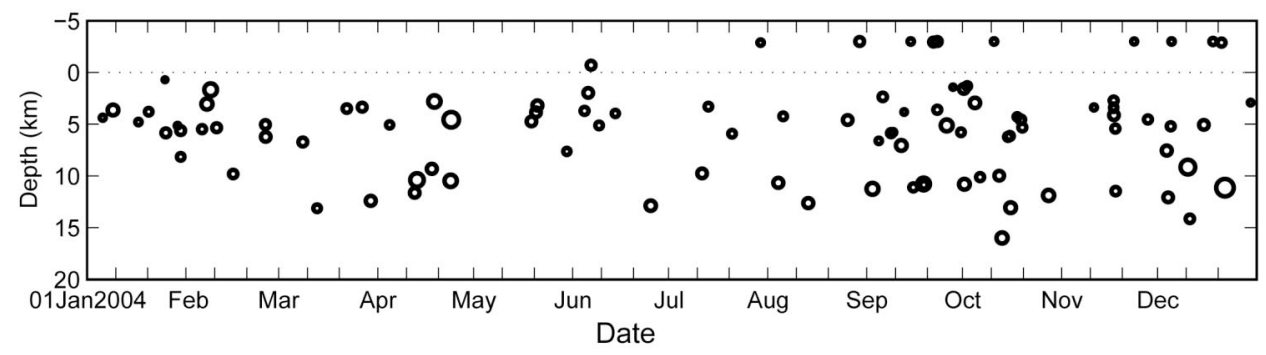

Figure A3. Summary plots of 99 earthquakes located near Redoubt Volcano in 2004. Open circles scaled with magnitude show hypocenter locations. Seismograph stations are shown by open squares and labeled by station code. (See Appendix B for station information). Solid triangles are used to show volcanic centers and closed squares are used to show other points of interest. 
Iliamna Volcano Seismicity
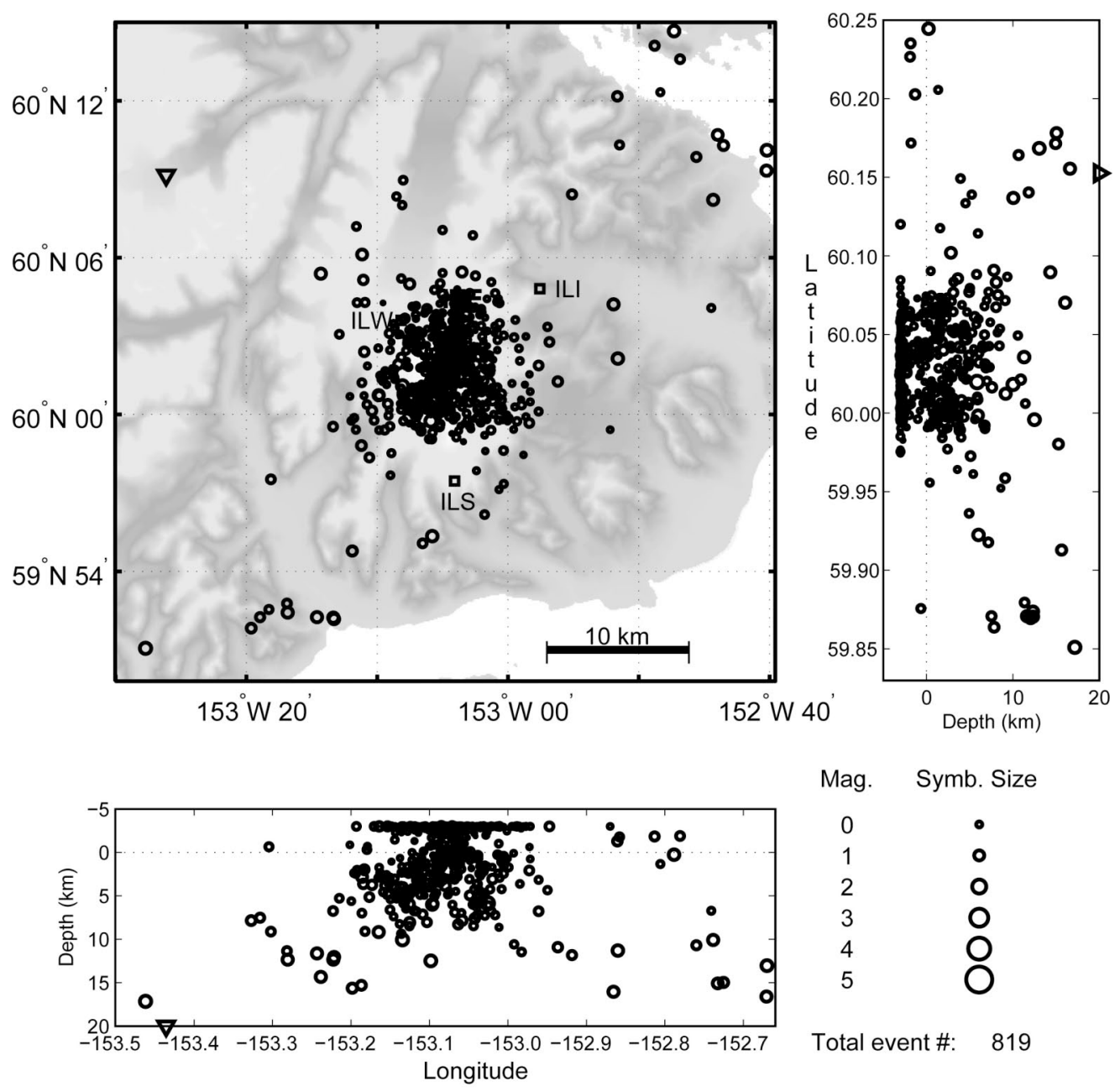

Mag. Symb. Size
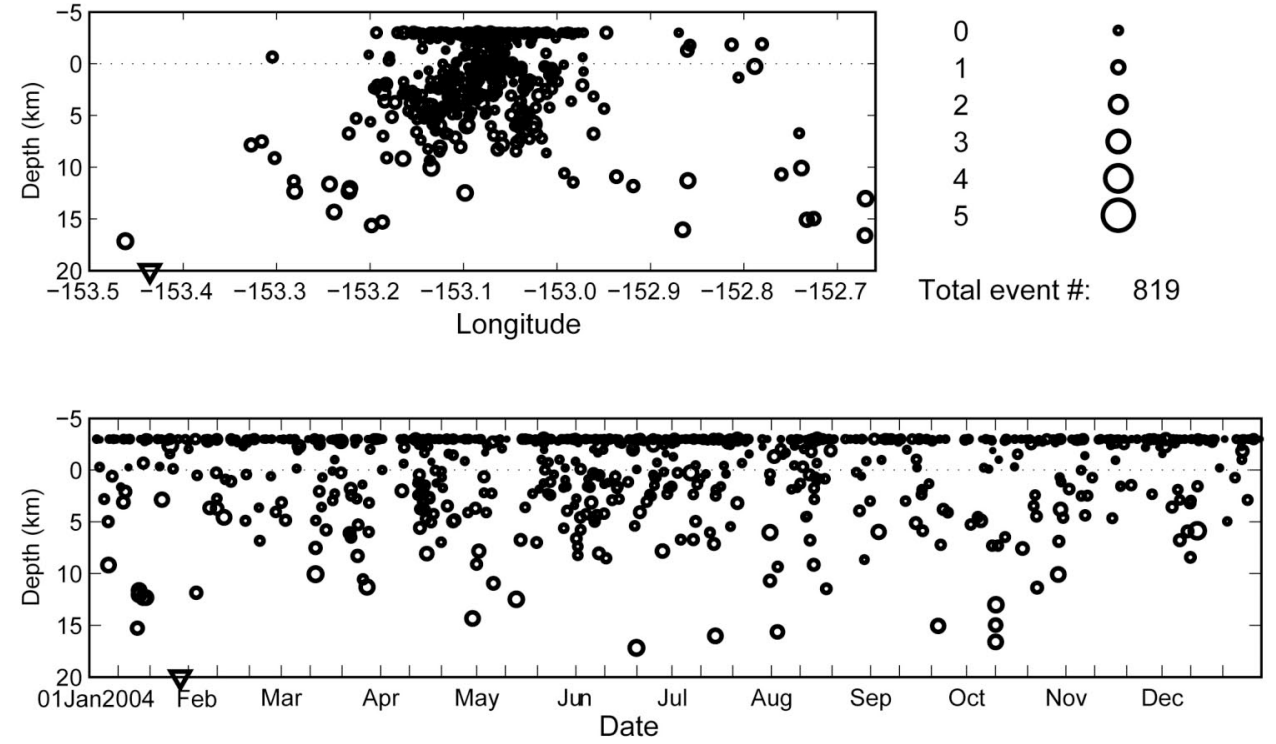

Figure A4. Summary plots of 819 earthquakes located near Iliamna Volcano in 2004. Open circles show hypocenter locations shallower than $20 \mathrm{~km}$ and open triangles show hypocenters with depths of $20 \mathrm{~km}$ and deeper. Hypocenter symbols are scaled with magnitude. Seismograph stations are shown by open squares and labeled by station code. (See Appendix B for station information). Solid triangles are used to show volcanic centers and closed squares are used to show other points of interest. 

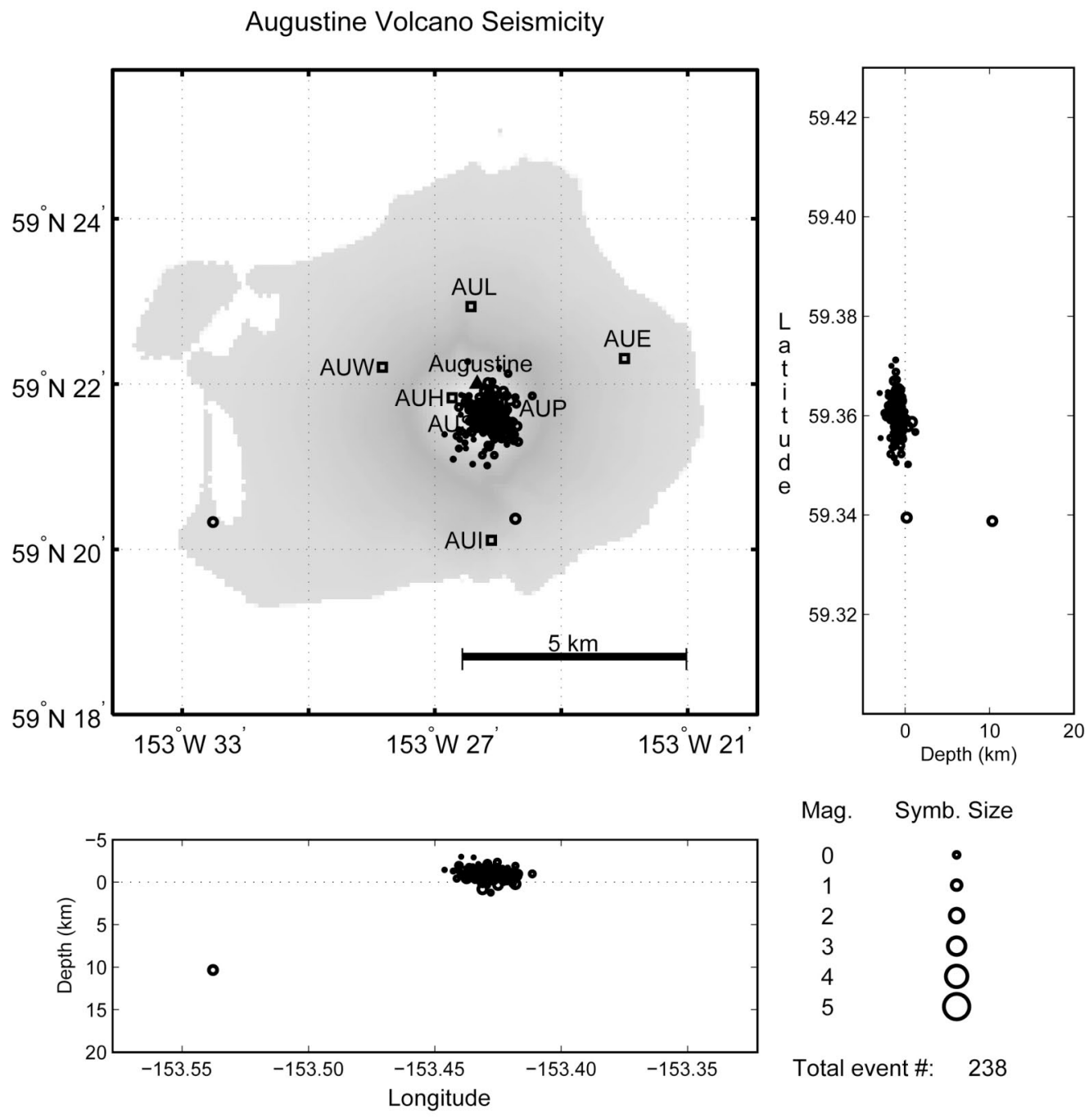

Mag. Symb. Size
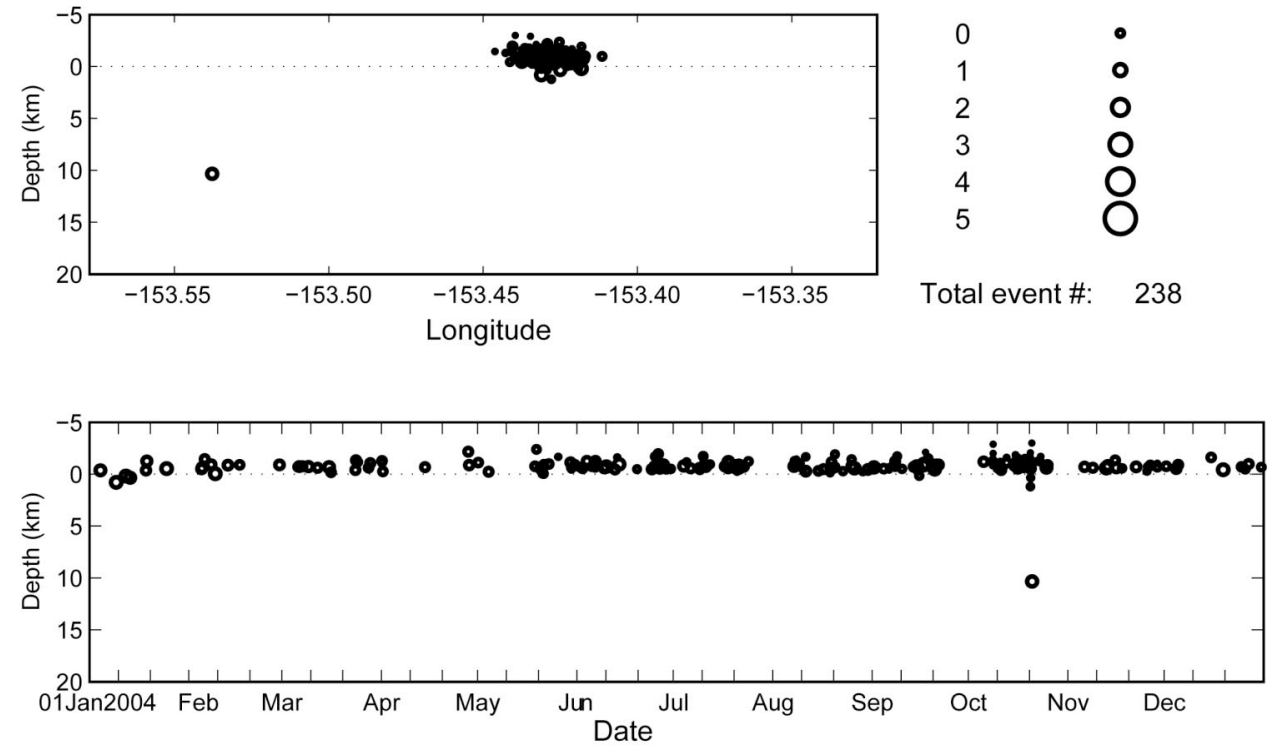

Figure A5. Summary plots of 238 earthquakes located near Augustine Volcano in 2004. Open circles scaled with magnitude show hypocenter locations. Seismograph stations are shown by open squares and labeled by station code. (See Appendix B for station information). Solid triangles are used to show volcanic centers and closed squares are used to show other points of interest. 
Katmai Volcanic Cluster Seismicity
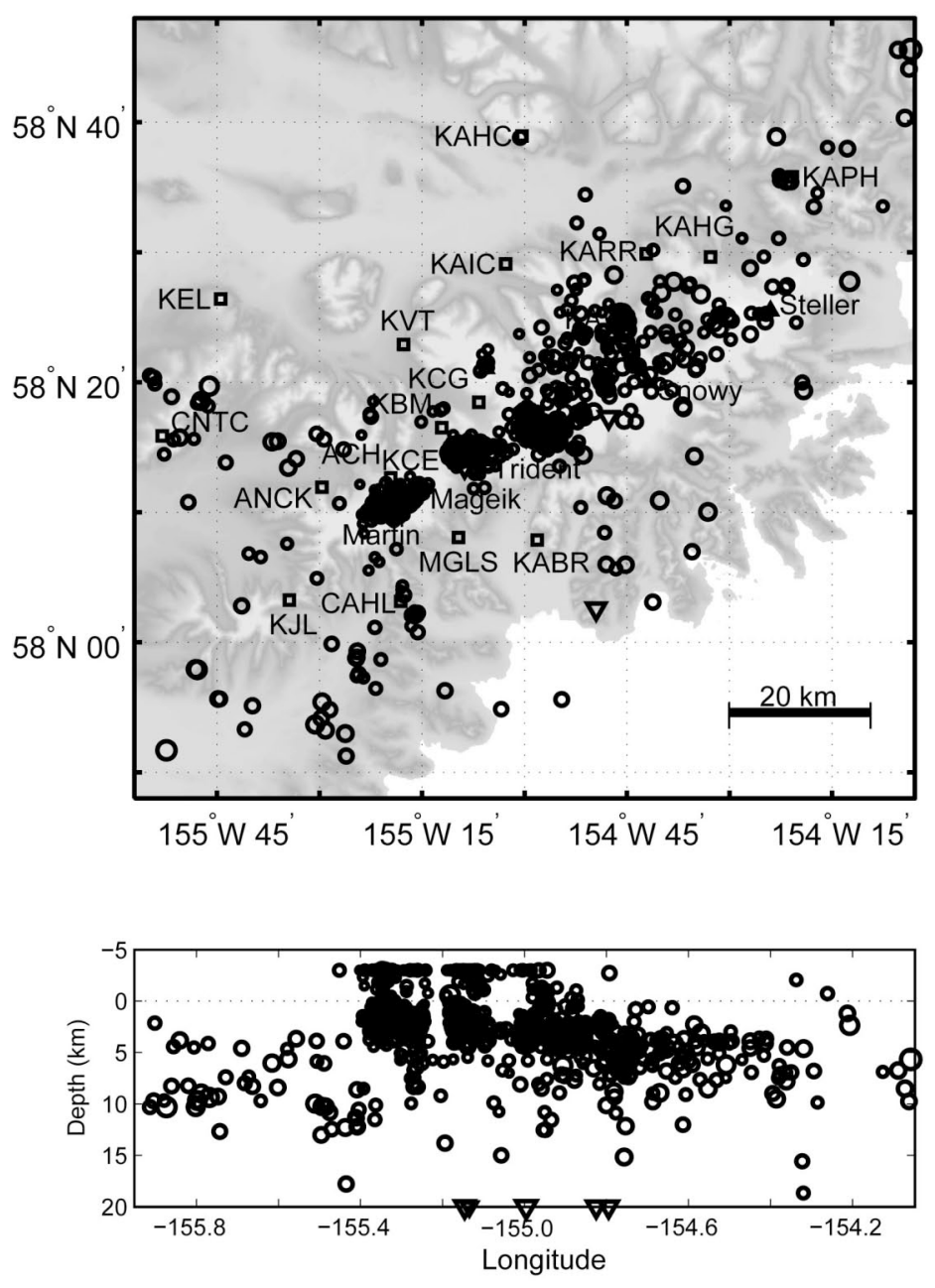

Mag. Symb. Size
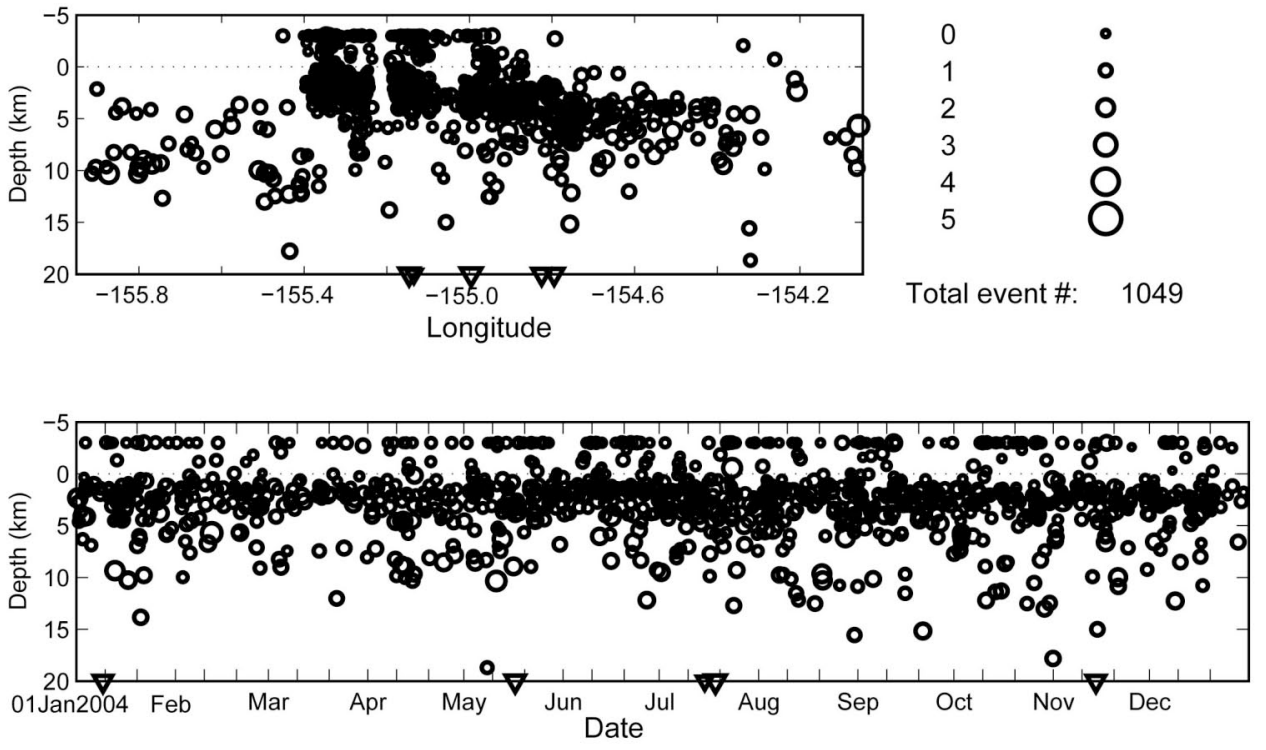

Figure A6. Summary plots of 1049 earthquakes located near the Katmai volcanic cluster in 2004. Open circles show hypocenter locations shallower than $20 \mathrm{~km}$ and open triangles show hypocenters with depths of $20 \mathrm{~km}$ and deeper. Hypocenter symbols are scaled with magnitude. Seismograph stations are shown by open squares and labeled by station code. (See Appendix B for station information). Solid triangles are used to show volcanic centers and closed squares are used to show other points of interest. 
Snowy Mountain Seismicity
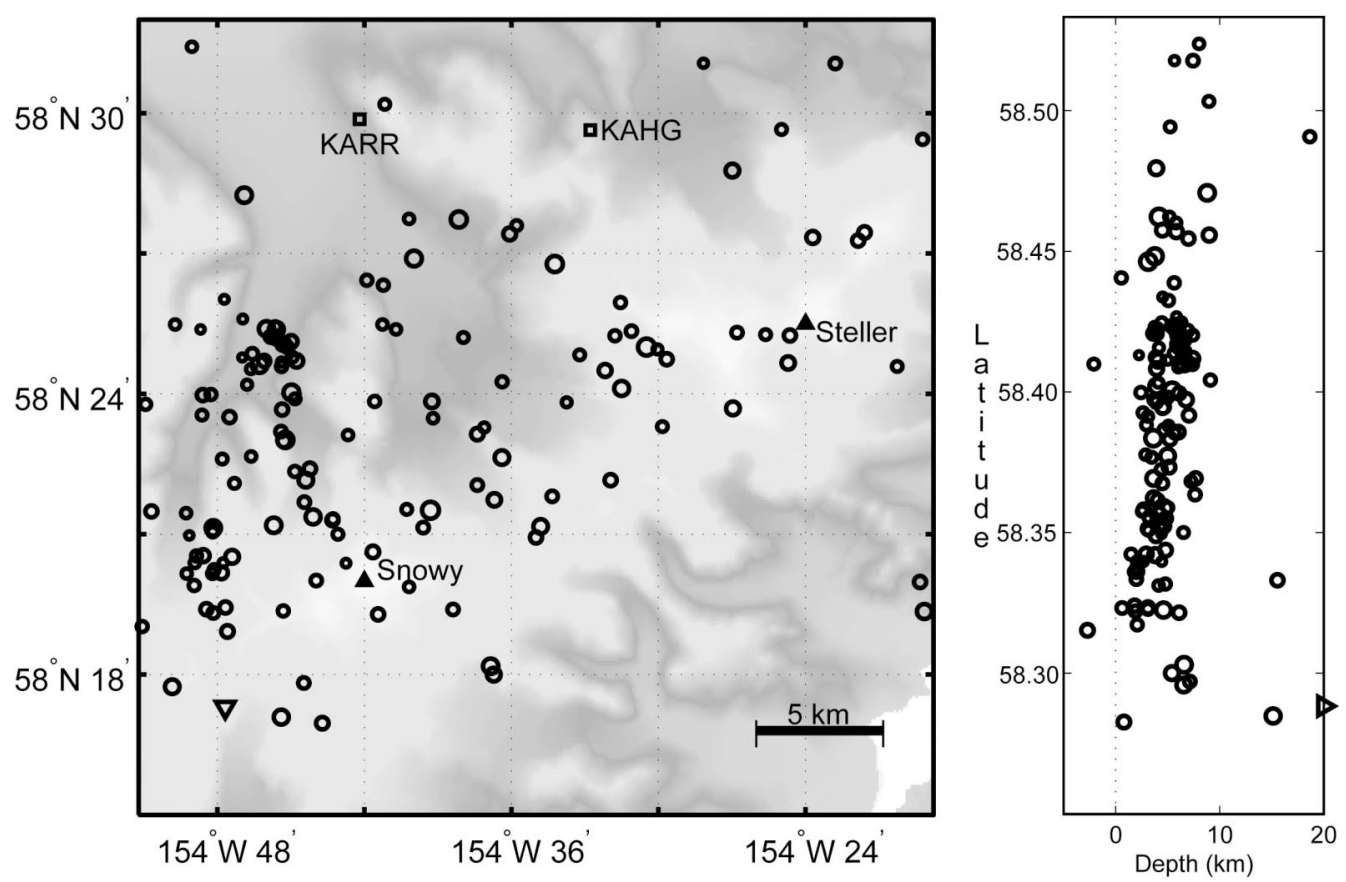

Mag. Symb. Size
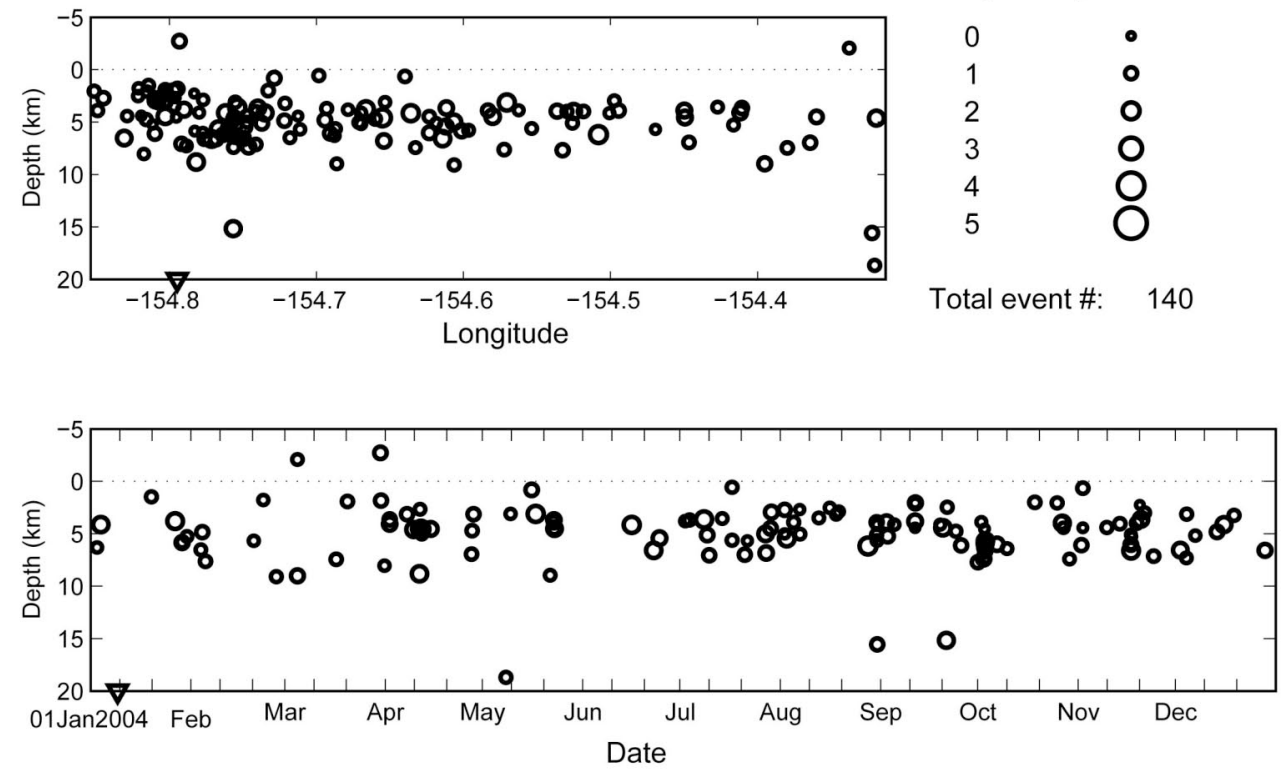

Figure A7. Summary plots of 140 earthquakes located near Snowy Mountain in the Katmai volcanic cluster in 2004. Open circles show hypocenter locations shallower than $20 \mathrm{~km}$ and open triangles show hypocenters with depths of $20 \mathrm{~km}$ and deeper.

Hypocenter symbols are scaled with magnitude. Seismograph stations are shown by open squares and labeled by station code. (See Appendix B for station information). Solid triangles are used to show volcanic centers and closed squares are used to show other points of interest. 
Mount Griggs Seismicity
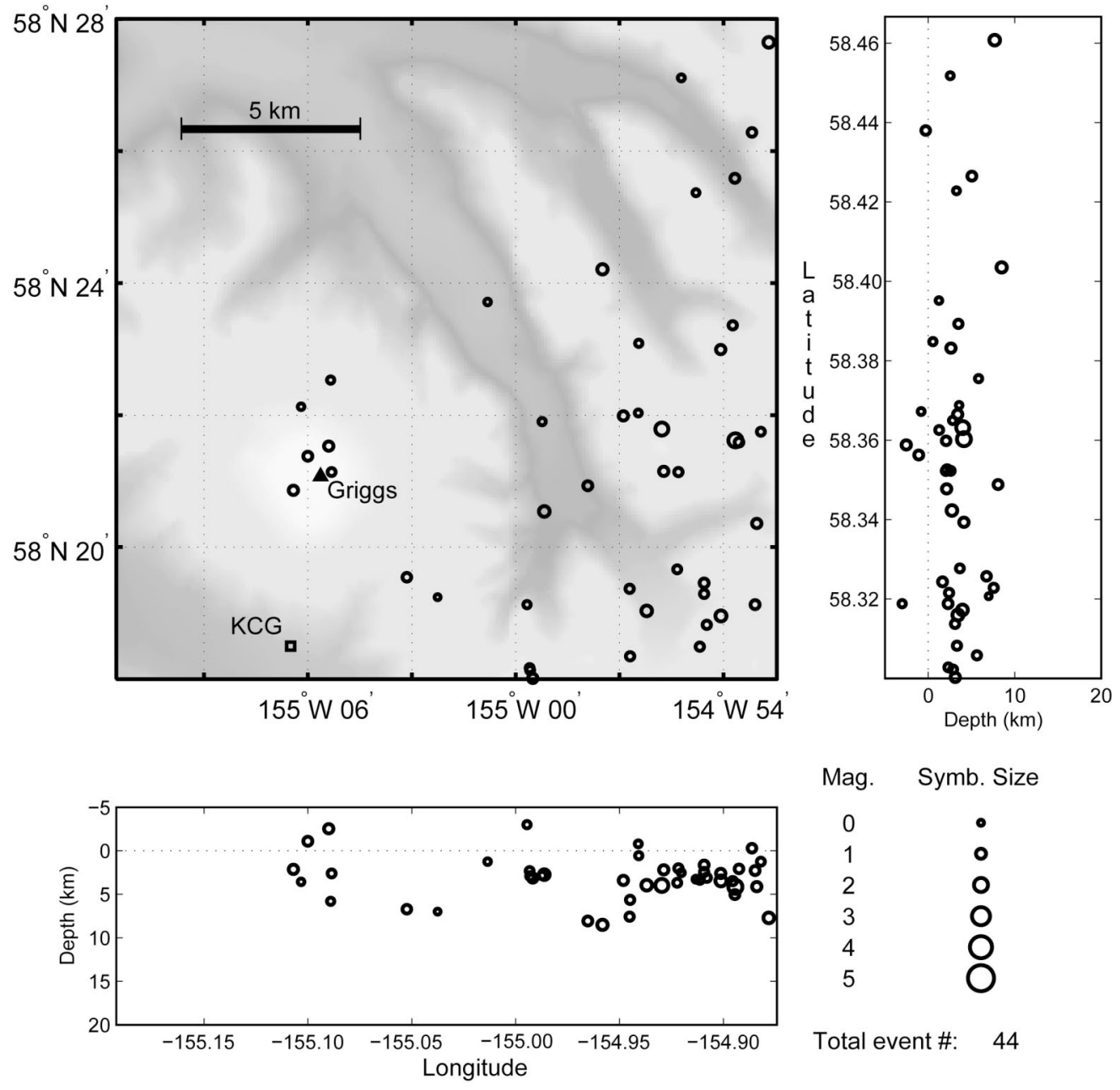

Mag. Symb. Size
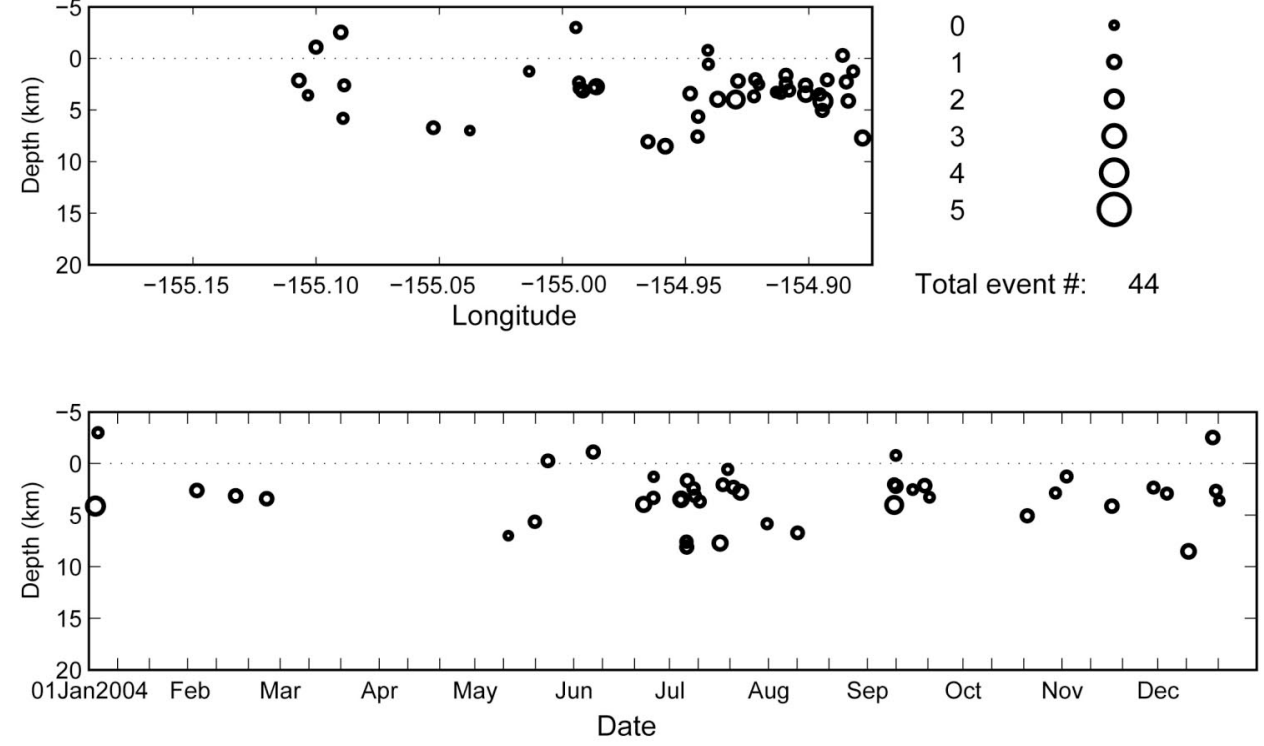

Figure A8. Summary plots of 44 earthquakes located near Mount Griggs in the Katmai volcanic cluster in 2004. Open circles scaled with magnitude show hypocenter locations. Seismograph stations are shown by open squares and labeled by station code. (See Appendix B for station information). Solid triangles are used to show volcanic centers and closed squares are used to show other points of interest. Several earthquakes that appear on this figure appear on other figures. 
Mount Katmai Seismicity
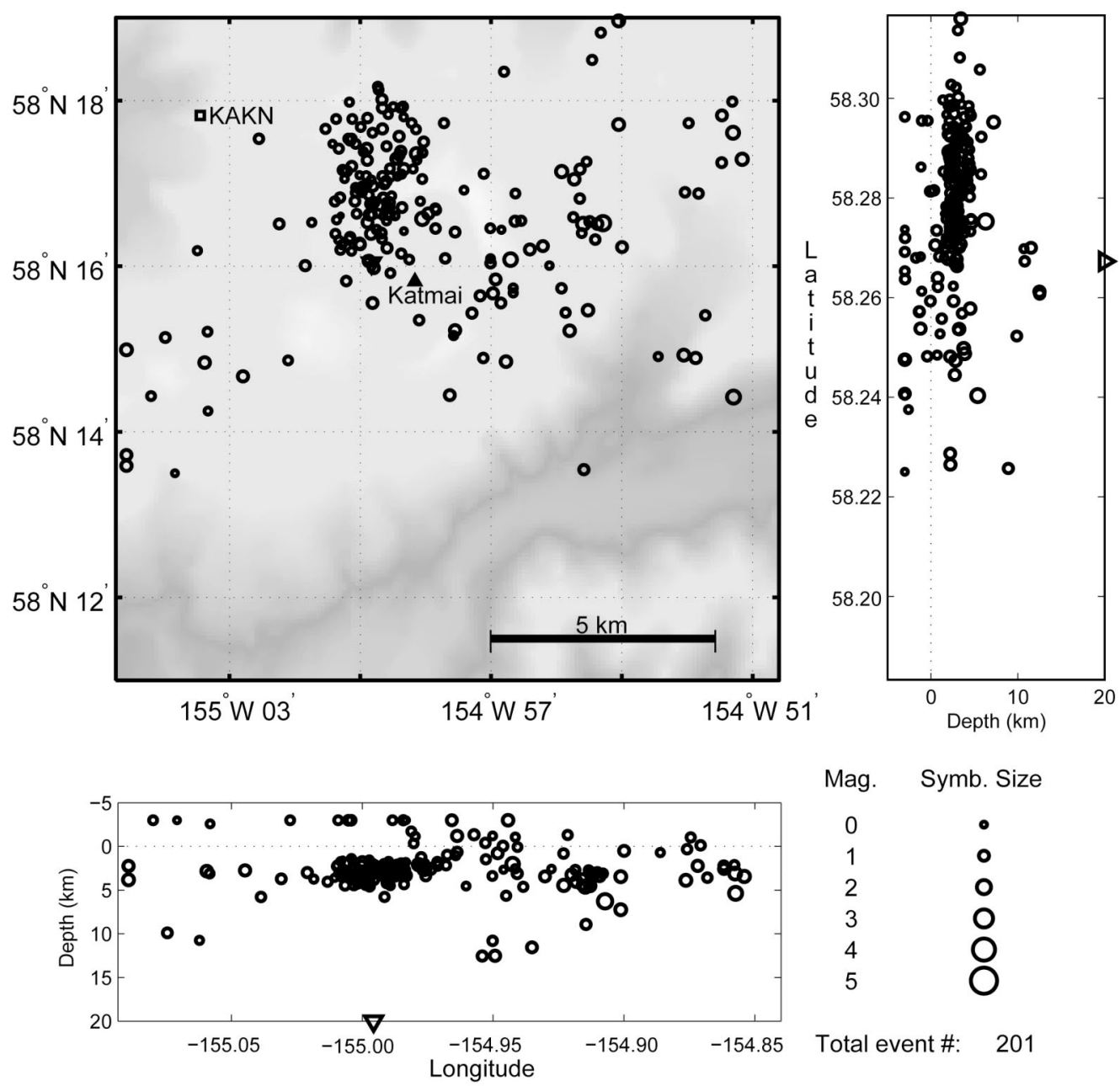

Mag. Symb. Size
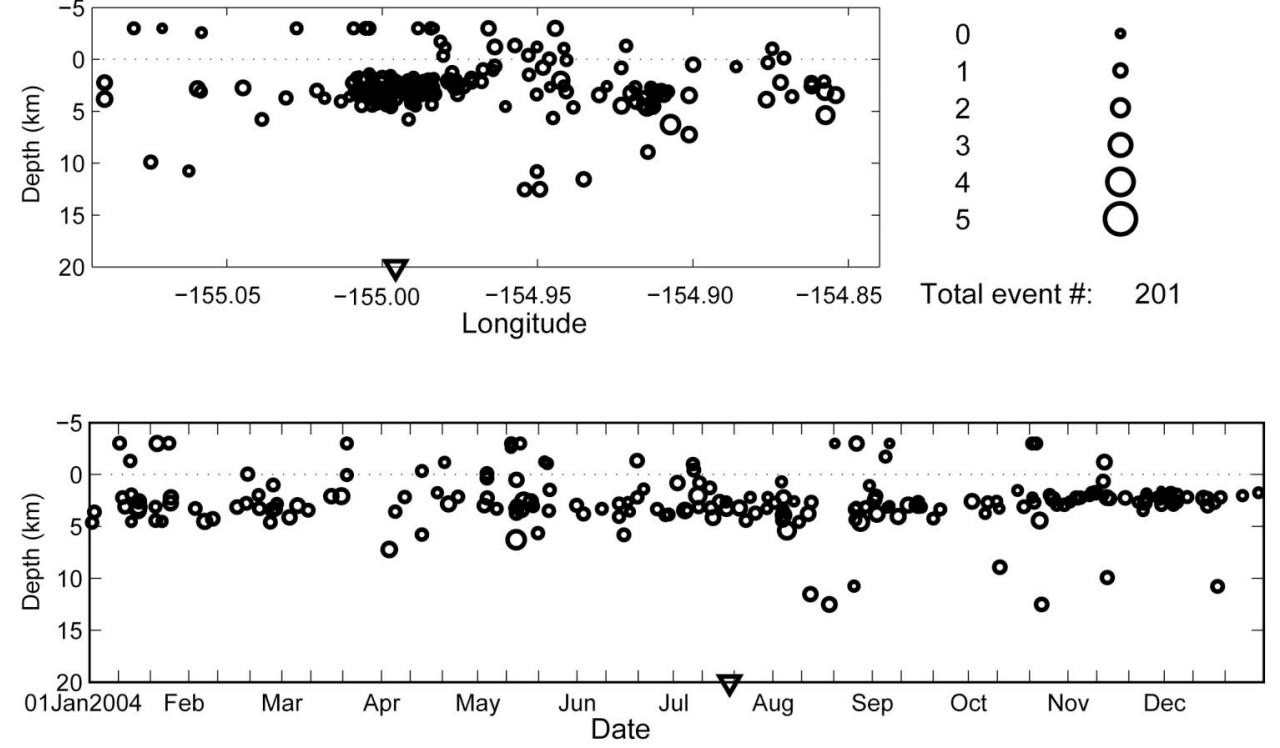

Figure A9. Summary plots of 201 earthquakes located near Mount Katmai in the Katmai volcanic cluster in 2004. Open circles show hypocenter locations shallower than $20 \mathrm{~km}$ and open triangles show hypocenters with depths of $20 \mathrm{~km}$ and deeper. Hypocenter symbols are scaled with magnitude. Seismograph stations are shown by open squares and labeled by station code. (See Appendix B for station information). Solid triangles are used to show volcanic centers and closed squares are used to show other points of interest. Several earthquakes that appear on this figure appear on other figures. 
Novarupta/Trident Volcano Seismicity
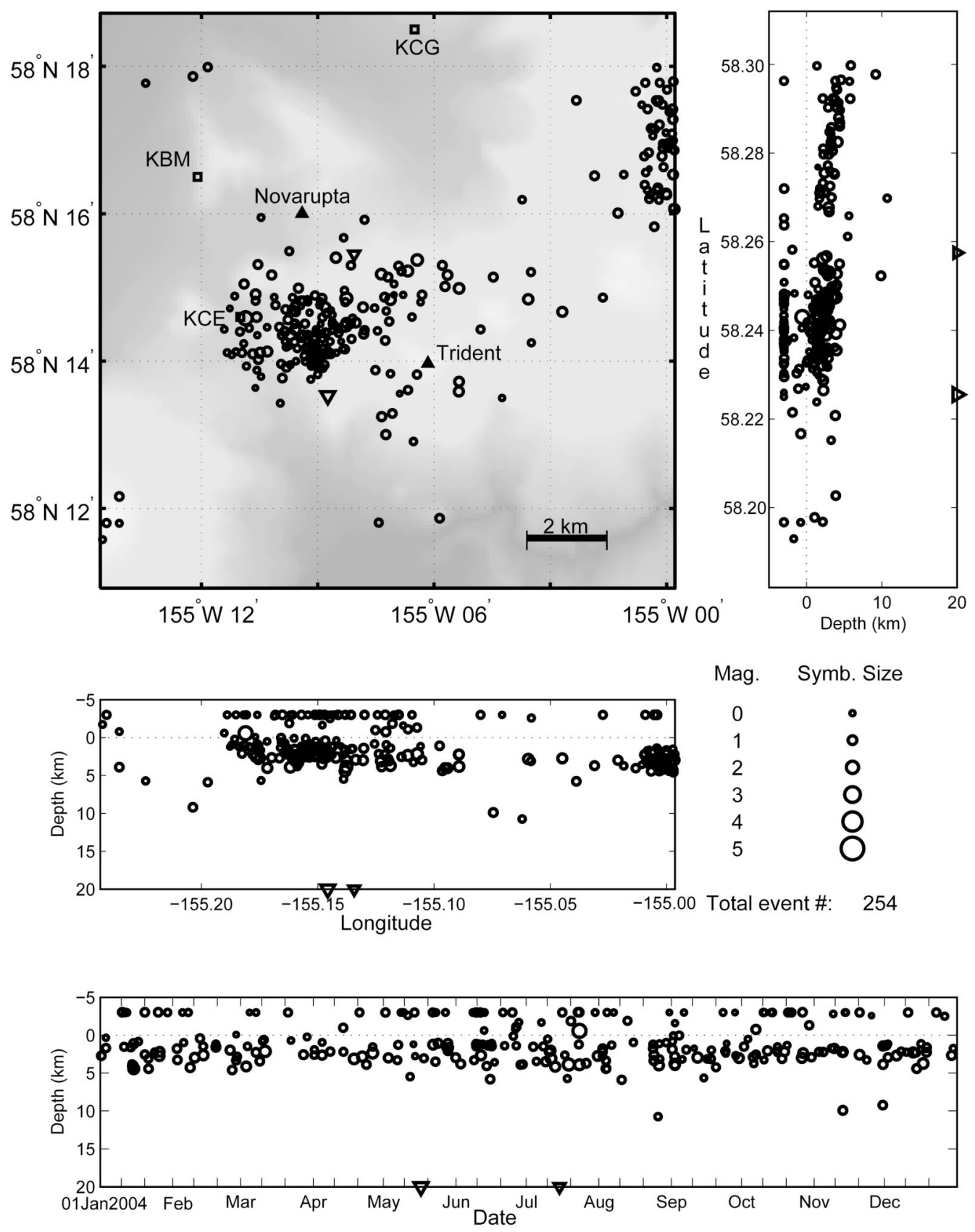

Figure A10. Summary plots of 254 earthquakes located near Novarupta and Trident Volcano in the Katmai volcanic cluster in 2004. Open circles show hypocenter locations shallower than $20 \mathrm{~km}$ and open triangles show hypocenters with depths of $20 \mathrm{~km}$ and deeper. Hypocenter symbols are scaled with magnitude. Seismograph stations are shown by open squares and labeled by station code. (See Appendix B for station information). Solid triangles are used to show volcanic centers and closed squares are used to show other points of interest. Several earthquakes that appear on this figure appear on other figures. 
Mount Martin/Mount Mageik Seismicity
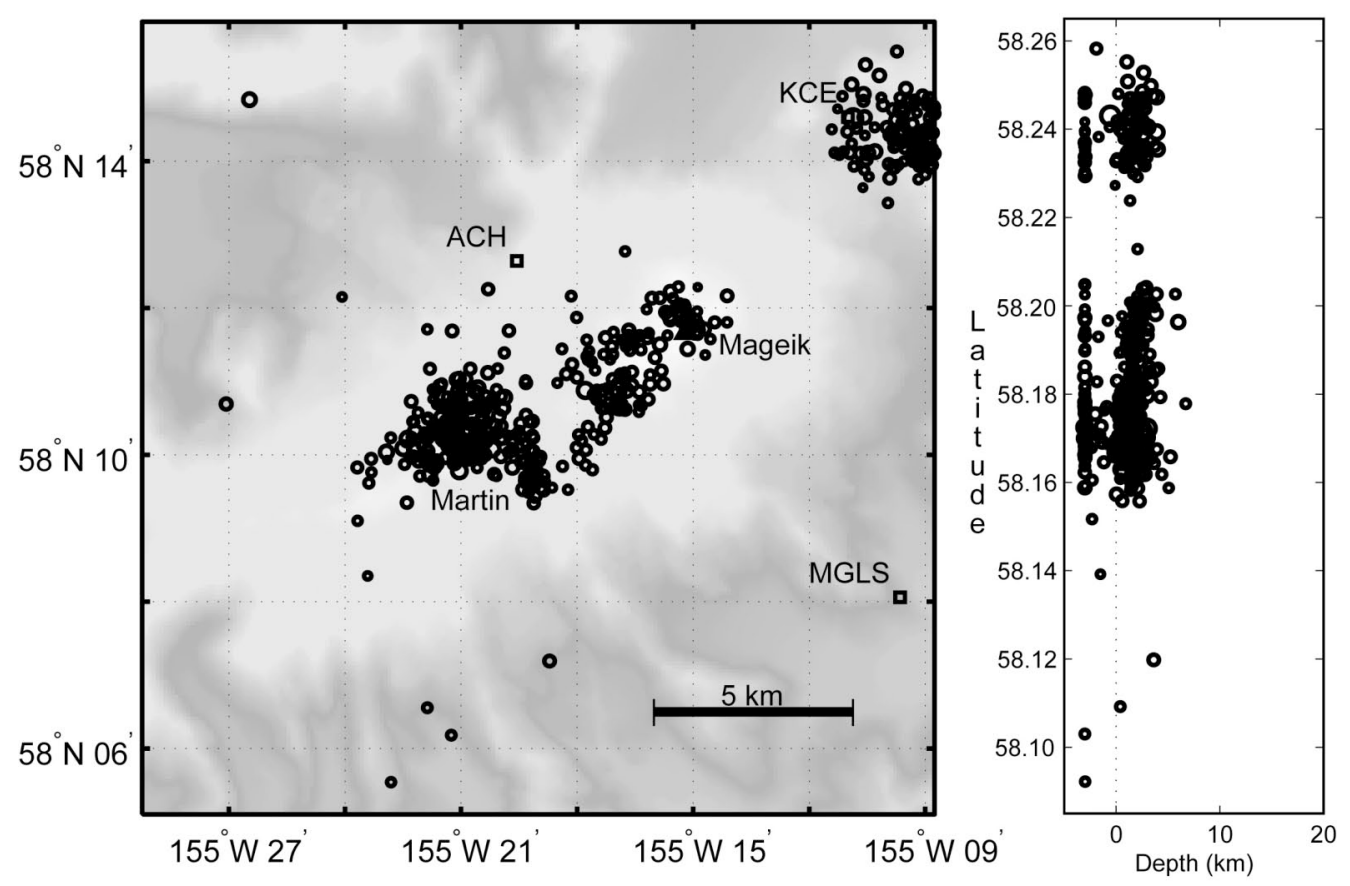

Mag. Symb. Size
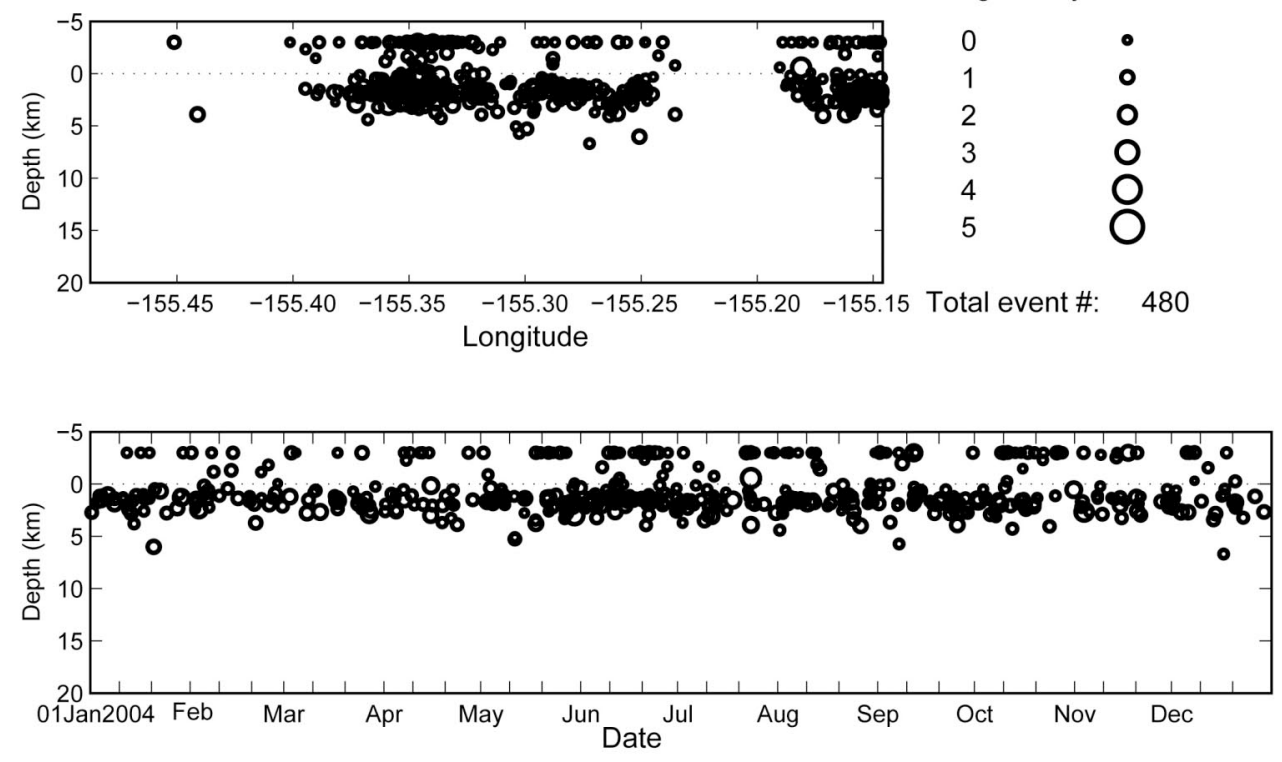

Figure A11. Summary plots of 480 earthquakes located near Mount Mageik and Mount Martin in the Katmai volcanic cluster in 2004. Open circles scaled with magnitude show hypocenter locations. Seismograph stations are shown by open squares and labeled by station code. (See Appendix B for station information). Solid triangles are used to show volcanic centers and closed squares are used to show other points of interest. Several earthquakes that appear on this figure appear on other figures. 

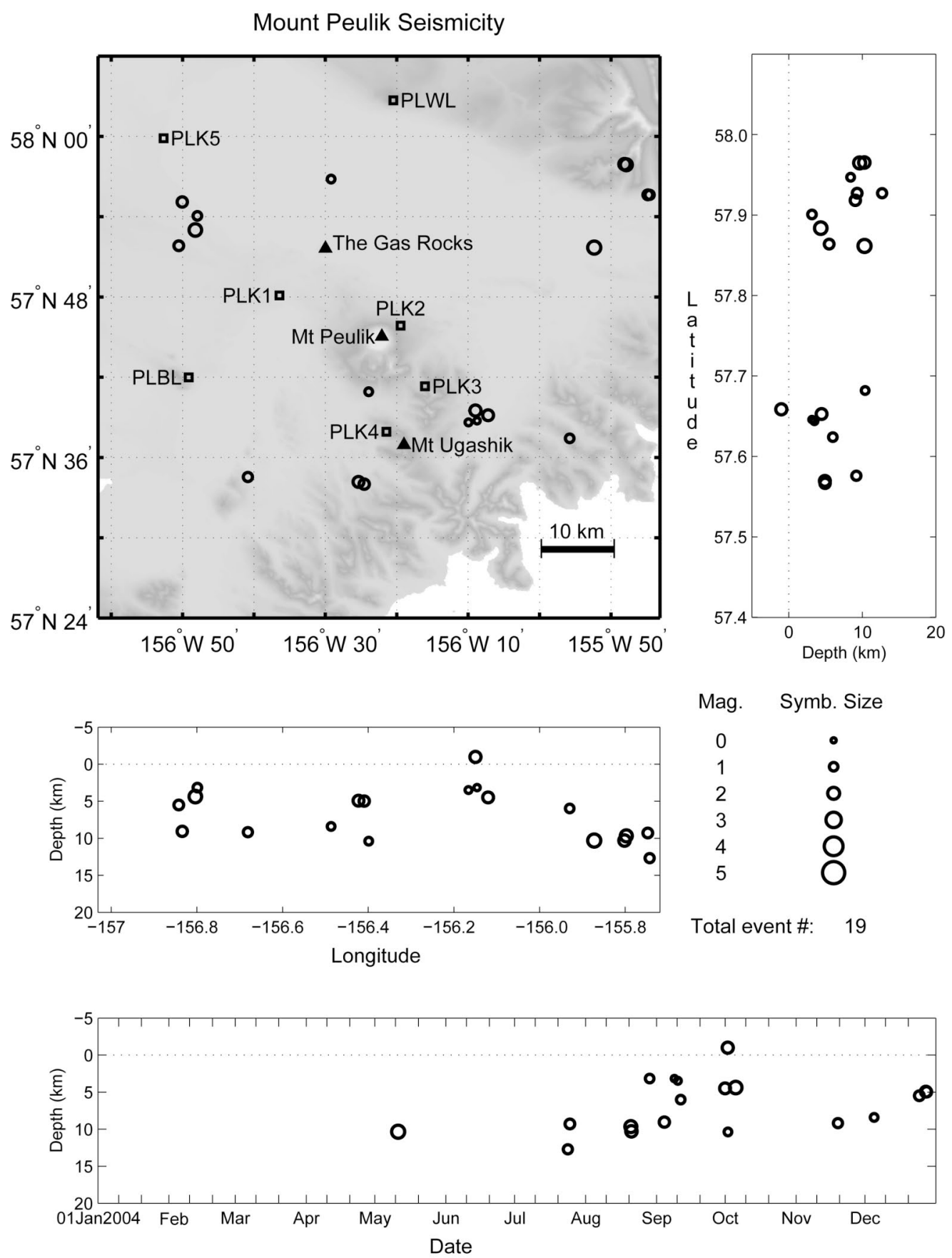

Figure A12. Summary plots of 19 earthquakes located near Mount Peulik in 2004. Open circles scaled with magnitude show hypocenter locations. Seismograph stations are shown by open squares and labeled by station code. (See Appendix B for station information). Solid triangles are used to show volcanic centers and closed squares are used to show other points of interest. The Peulik Subnetwork was installed in August 2004 and the three events located before August were located with only Katmai and/or Aniakchak seismic stations. 

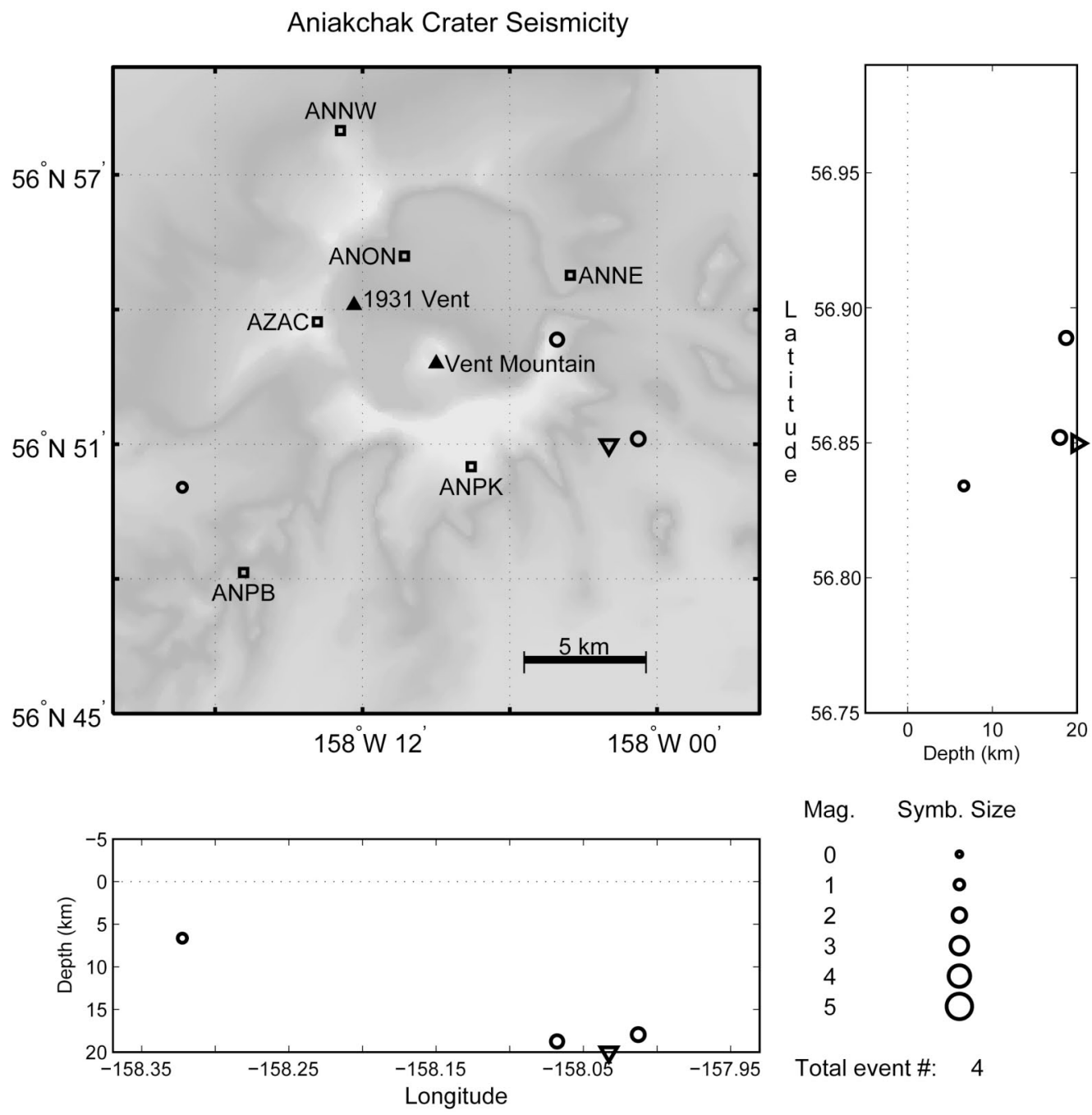

Mag. Symb. Size
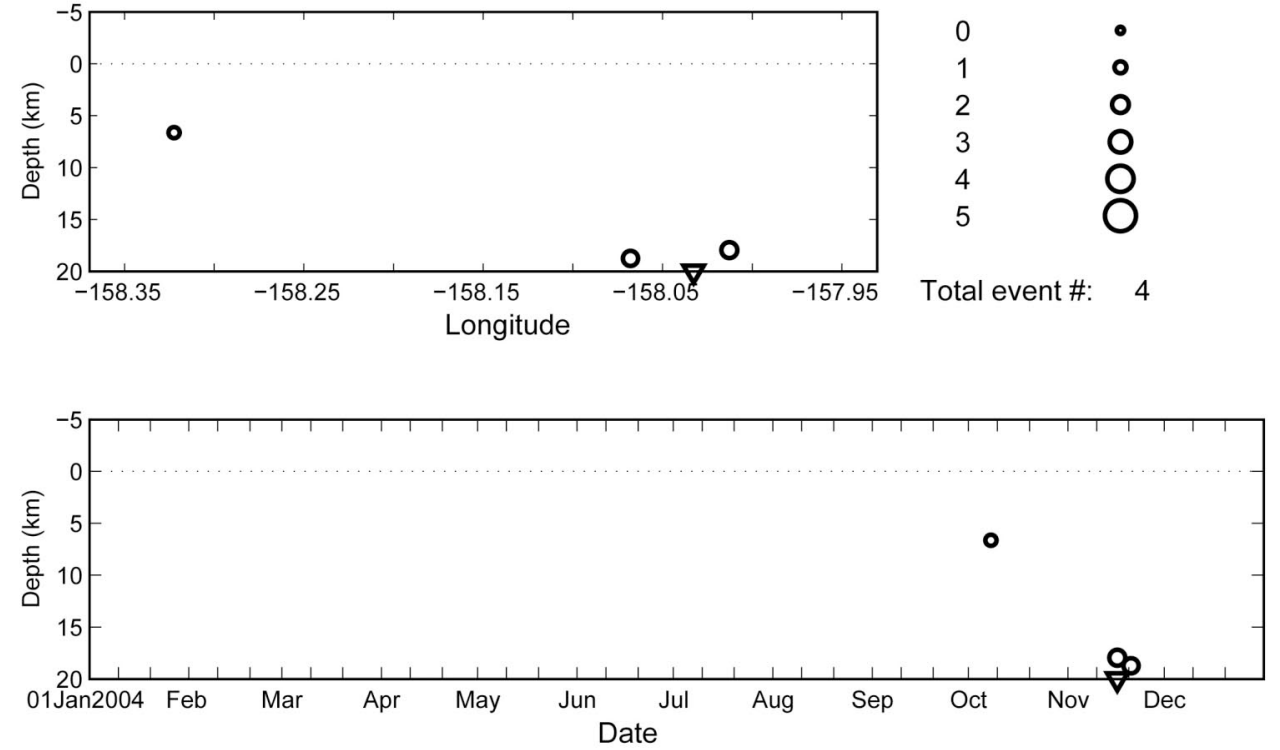

Figure A13. Summary plots of four earthquakes located near Aniakchak Crater in 2004. Open circles show hypocenter locations shallower than $20 \mathrm{~km}$ and open triangles show hypocenters with depths of $20 \mathrm{~km}$ and deeper. Hypocenter symbols are scaled with magnitude. Seismograph stations are shown by open squares and labeled by station code. (See Appendix B for station information). Solid triangles are used to show volcanic centers and closed squares are used to show other points of interest. 
Mount Veniaminof Seismicity
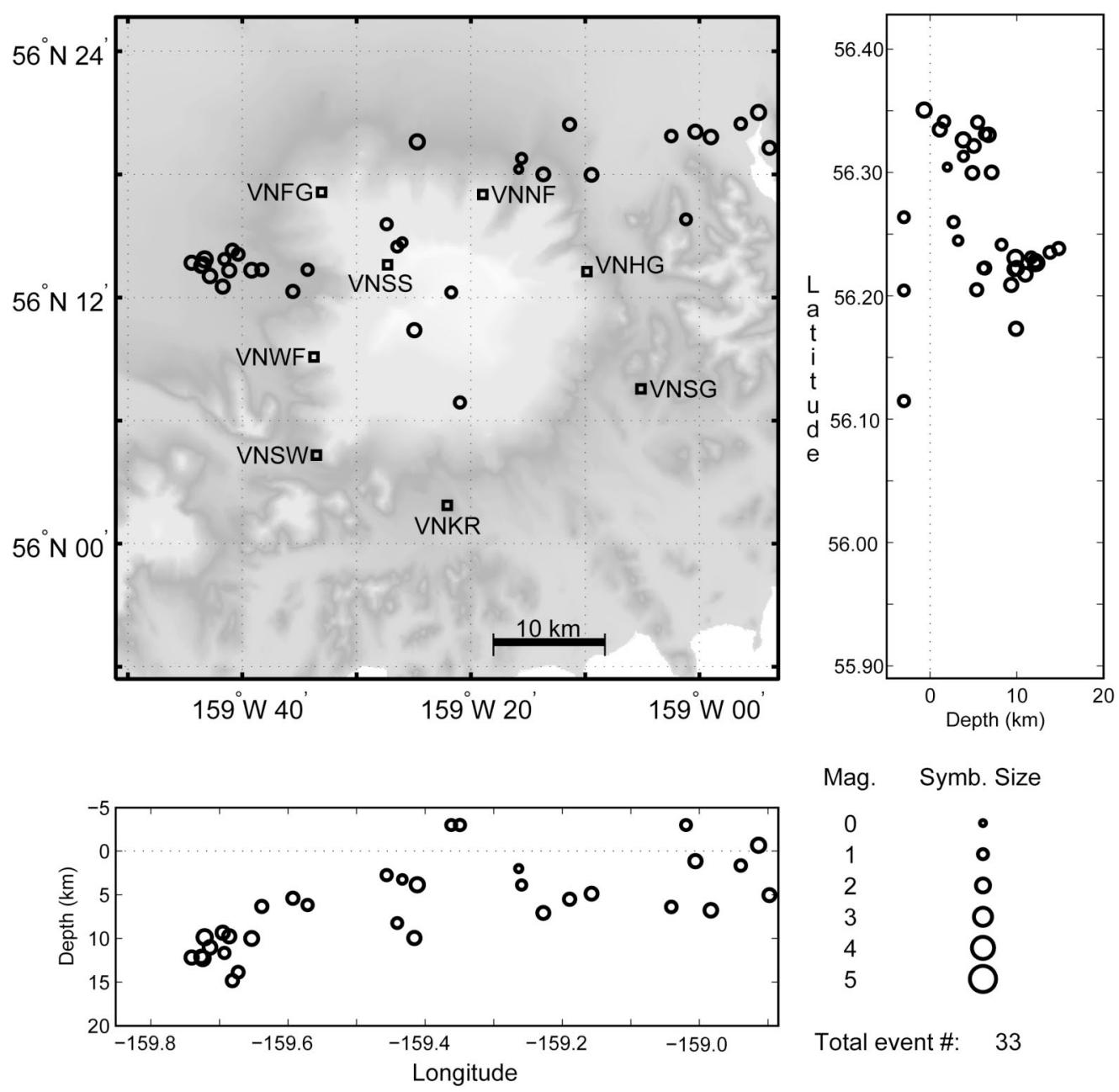

Mag. Symb. Size
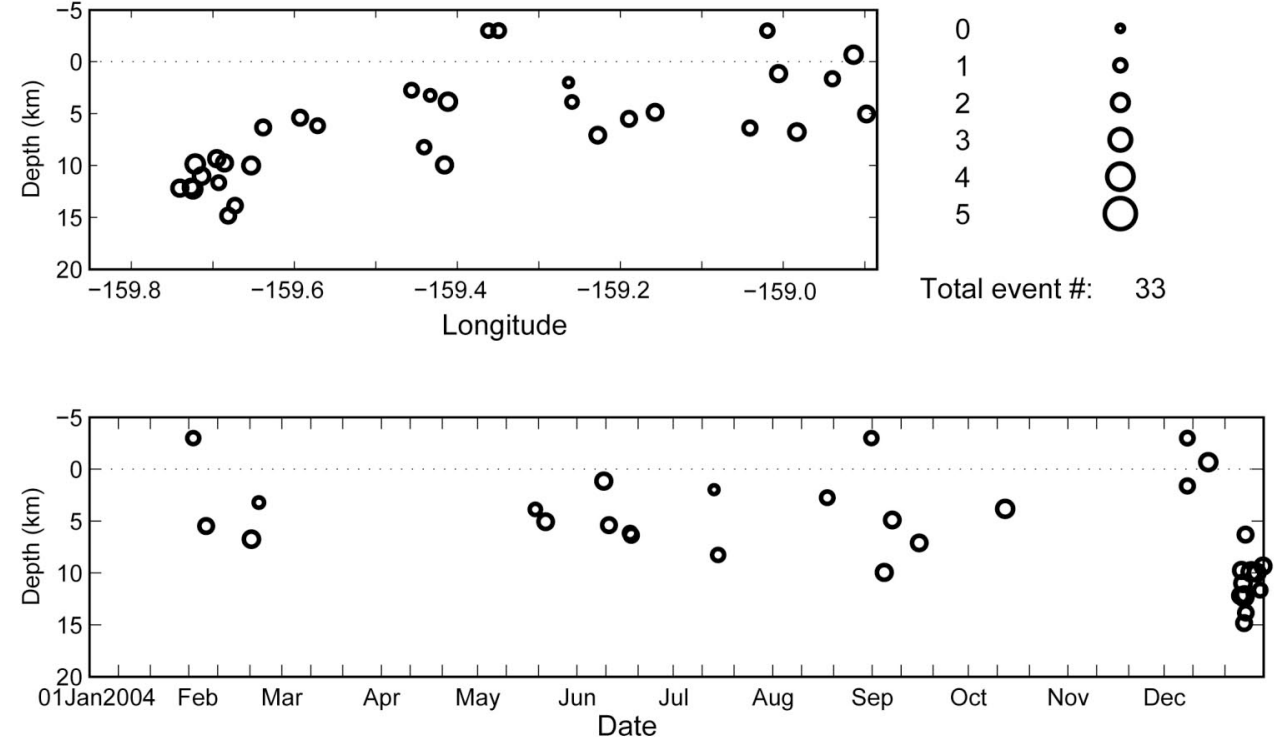

Figure A14. Summary plots of 33 earthquakes located near Mount Veniaminof in 2004. Open circles scaled with magnitude show hypocenter locations. Seismograph stations are shown by open squares and labeled by station code. (See Appendix B for station information). Solid triangles are used to show volcanic centers and closed squares are used to show other points of interest. 

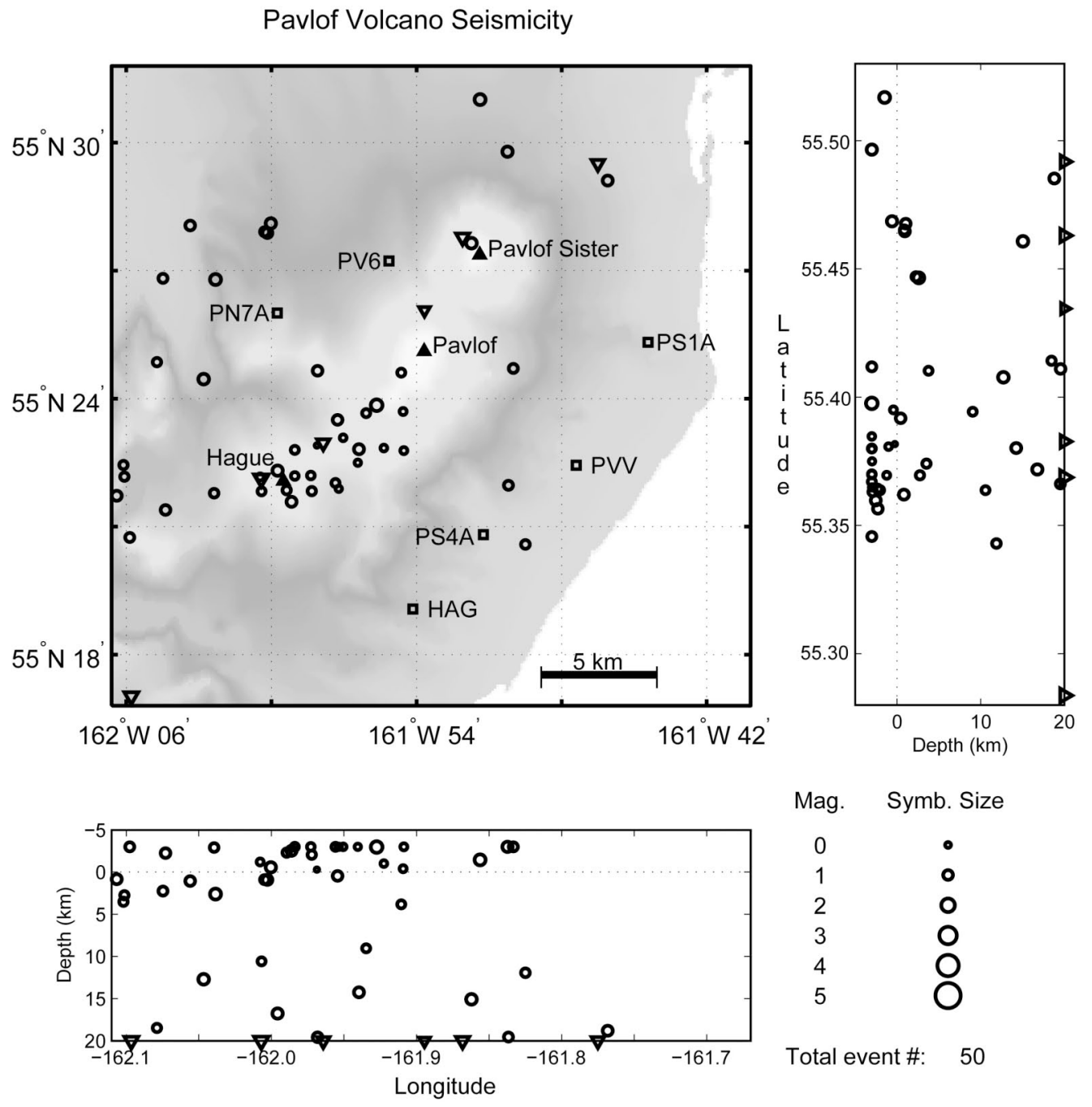

Mag. Symb. Size
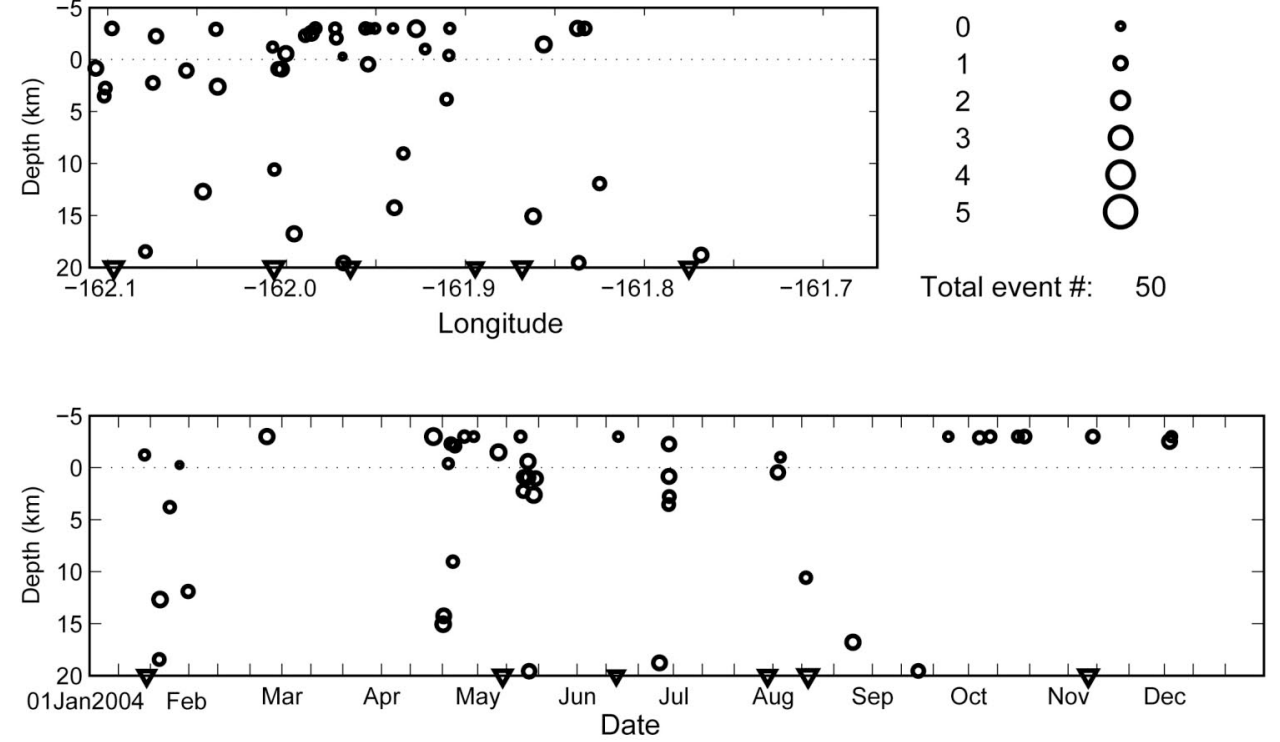

Figure A15. Summary plots of 50 earthquakes located near Pavlof Volcano in 2004. Open circles show hypocenter locations shallower than $20 \mathrm{~km}$ and open triangles show hypocenters with depths of $20 \mathrm{~km}$ and deeper. Hypocenter symbols are scaled with magnitude. Seismograph stations are shown by open squares and labeled by station code. (See Appendix B for station information). Solid triangles are used to show volcanic centers and closed squares are used to show other points of interest. 
Mount Dutton Seismicity
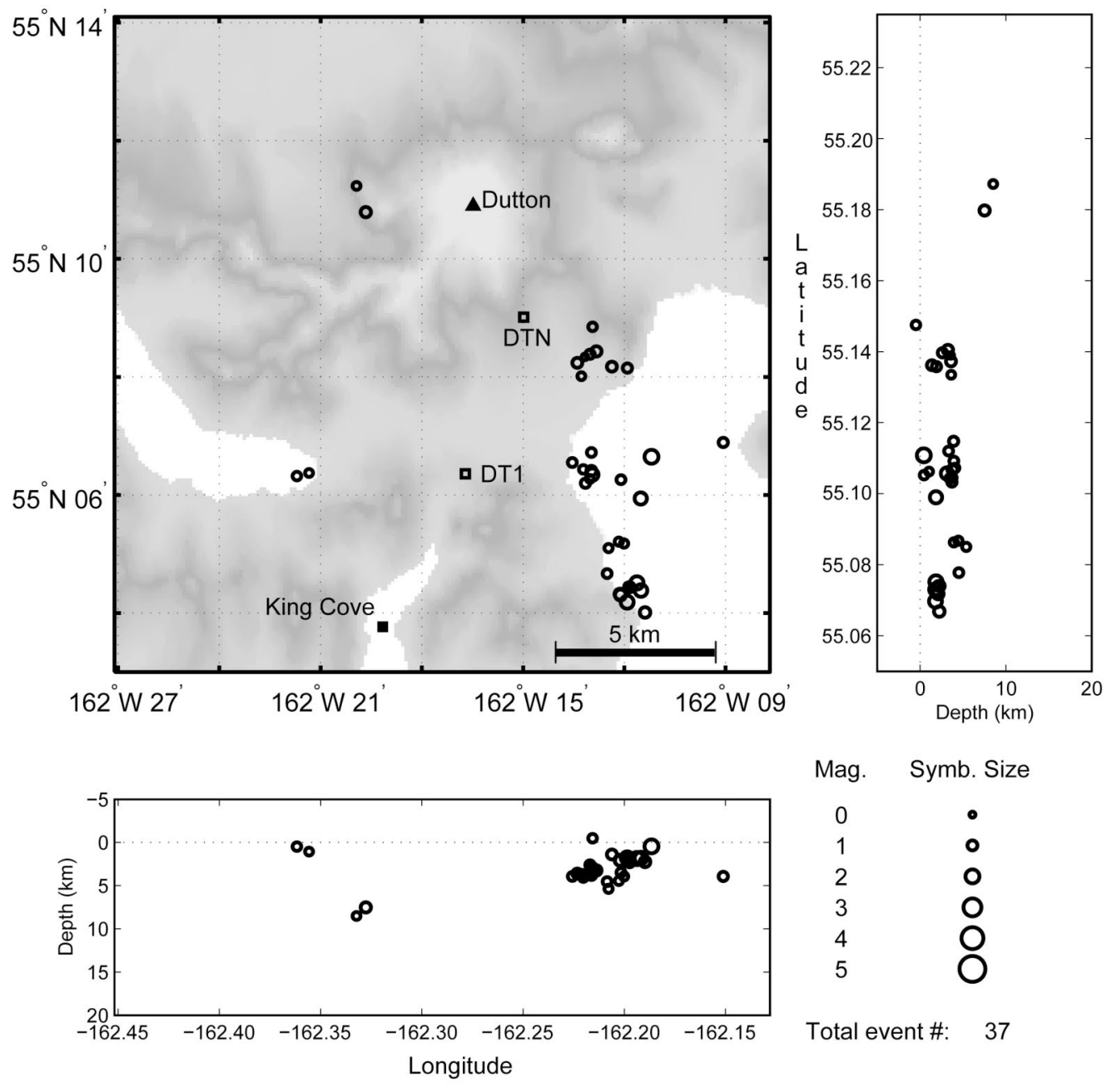

Mag. Symb. Size
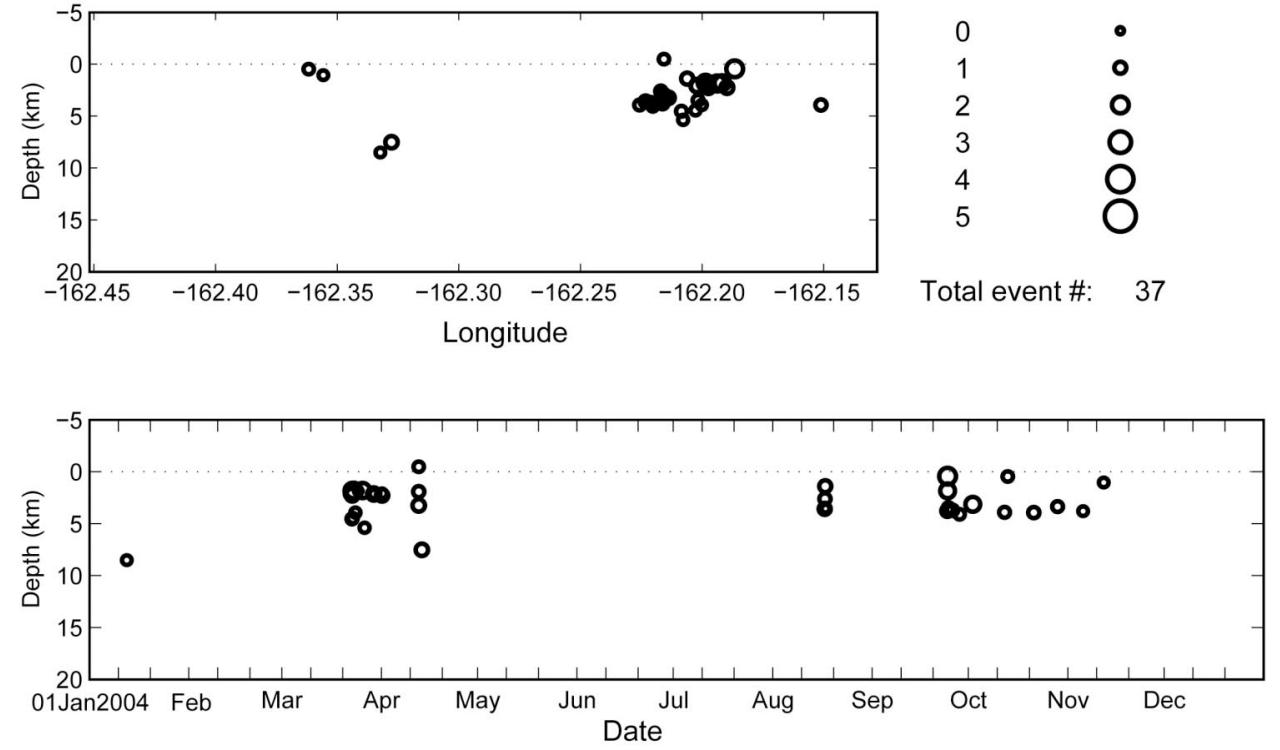

Figure A16. This summary plot shows 37 earthquakes located near Mount Dutton in 2004. Open circles scaled with magnitude show hypocenter locations. Seismograph stations are shown by open squares and labeled by station code. (See Appendix B for station information). Solid triangles are used to show volcanic centers and closed squares are used to show other points of interest. 
Unimak Island Seismicity
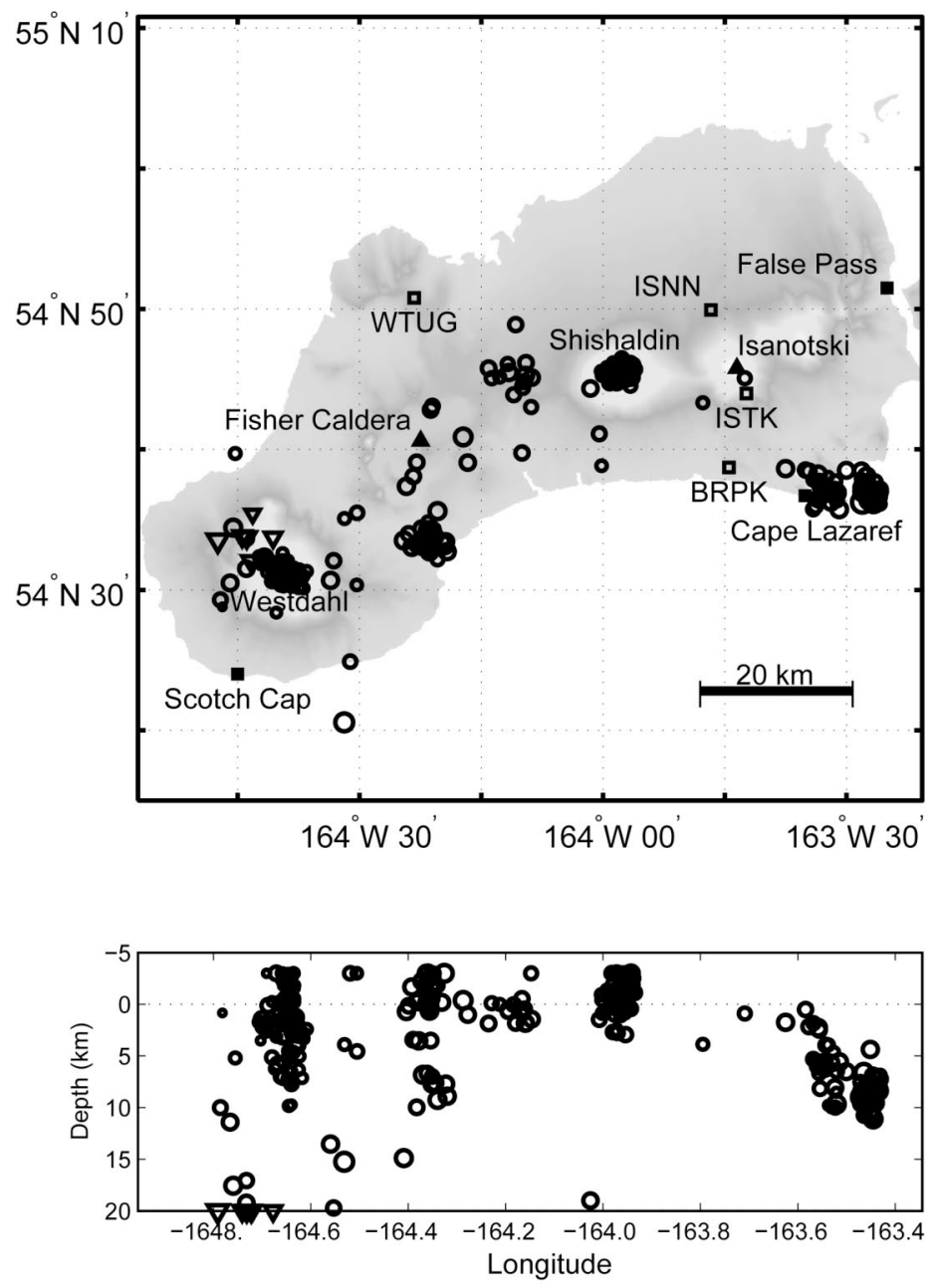

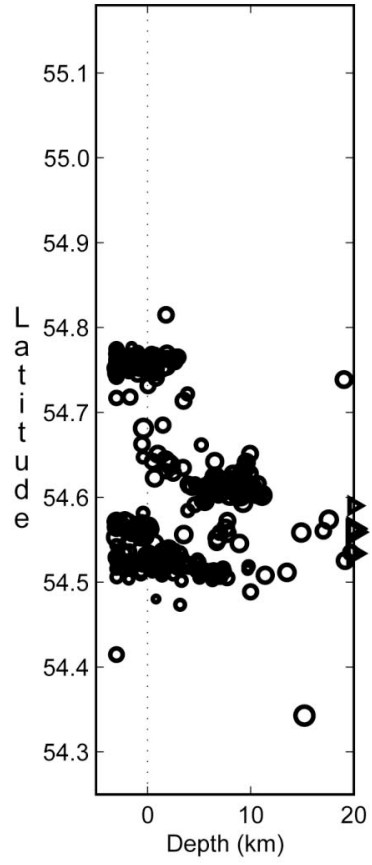

Mag. Symb. Size

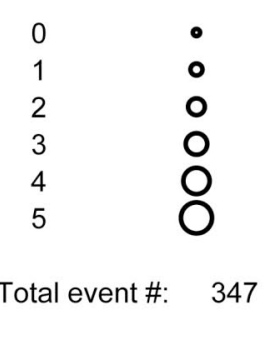

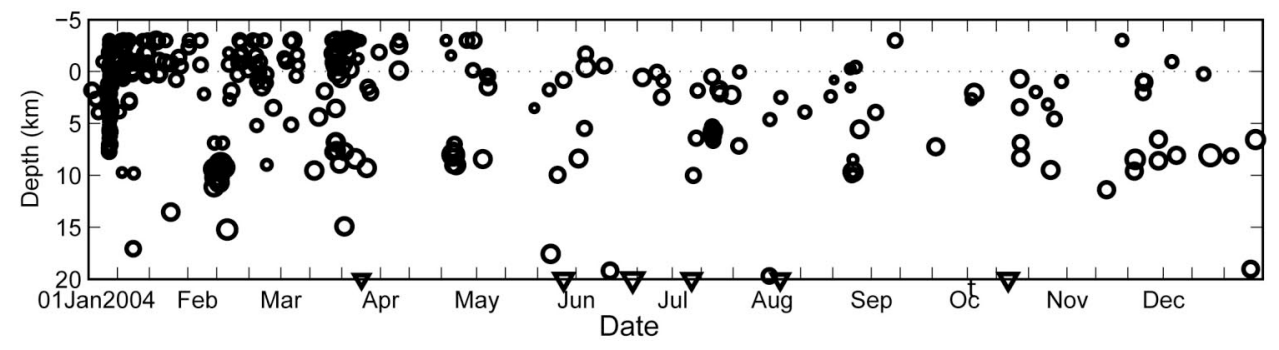

Figure A17. Summary plots of 347 earthquakes located near Unimak Island in 2004. Open circles show hypocenter locations shallower than $20 \mathrm{~km}$ and open triangles show hypocenters with depths of $20 \mathrm{~km}$ and deeper. Hypocenter symbols are scaled with magnitude. Seismograph stations are shown by open squares and labeled by station code. (See Appendix B for station information). Solid triangles are used to show volcanic centers and closed squares are used to show other points of interest. 
Shishaldin Volcano Seismicity
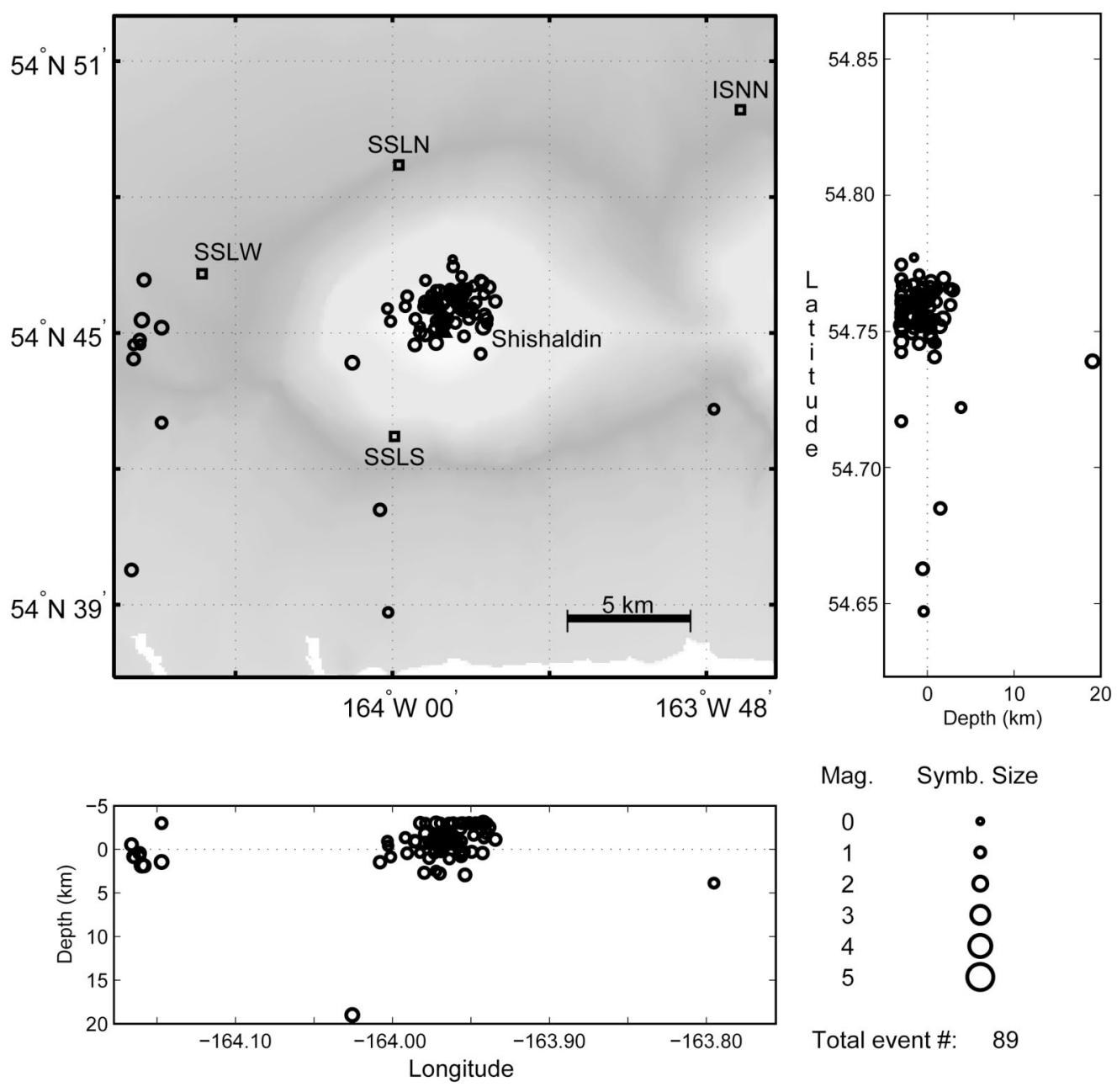

Mag. Symb. Size
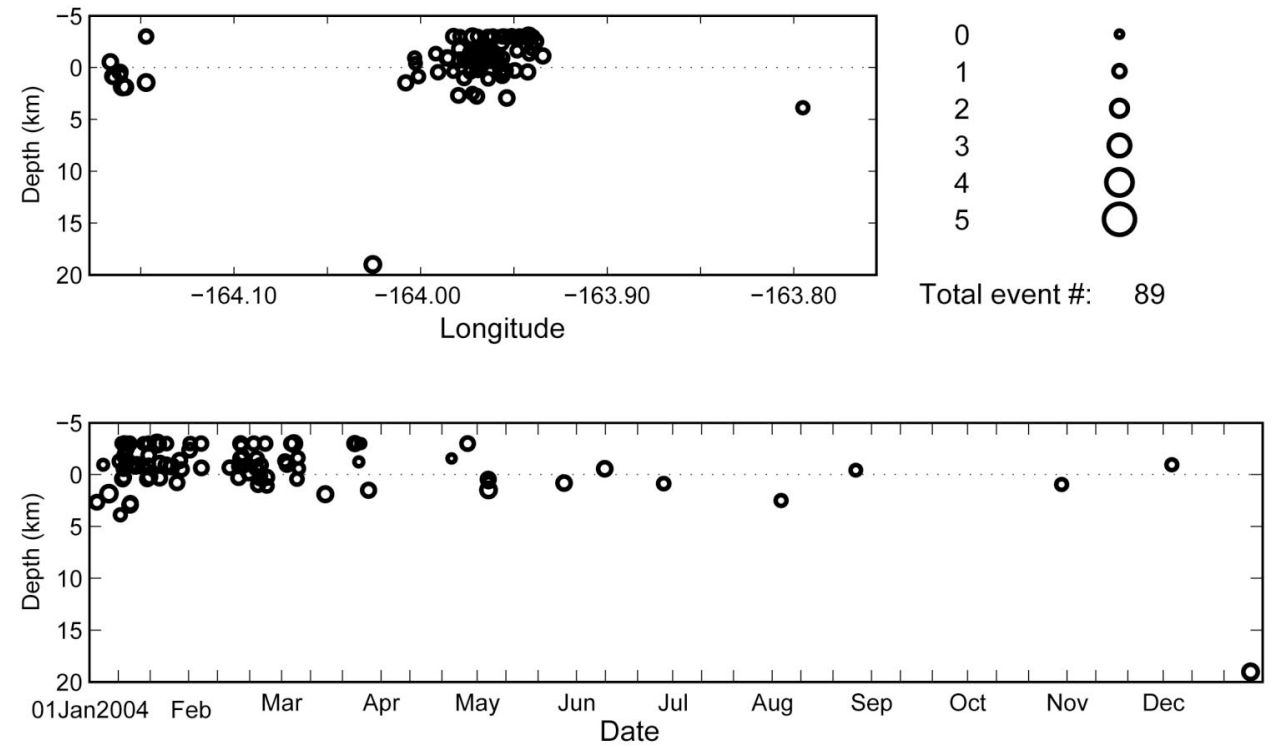

Figure A18. Summary plots of 89 earthquakes located near Shishaldin Volcano in 2004. Open circles scaled with magnitude show hypocenter locations. Seismograph stations are shown by open squares and labeled by station code. (See Appendix B for station information). Solid triangles are used to show volcanic centers and closed squares are used to show other points of interest. 
Westdahl Peak Seismicity
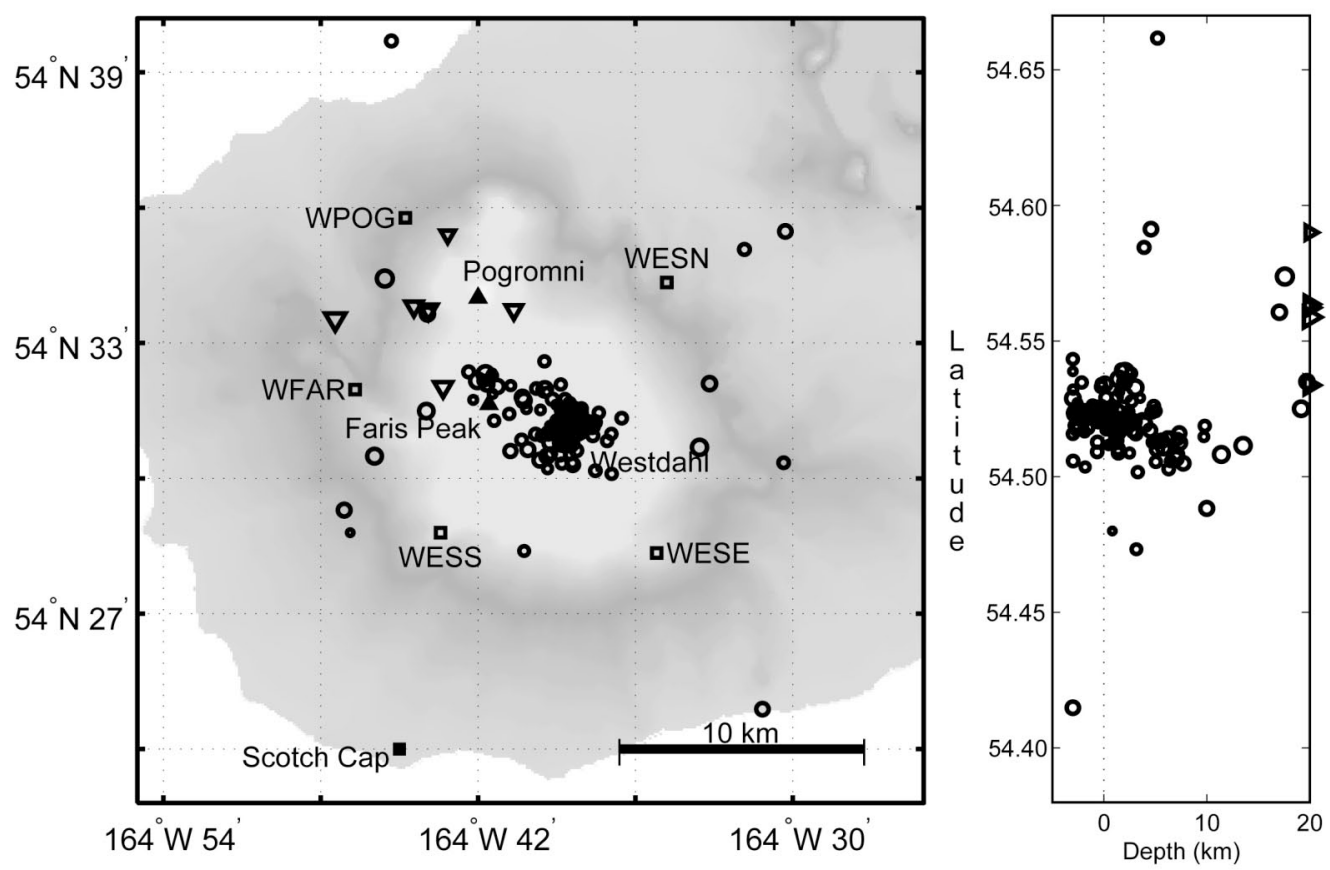

Mag. Symb. Size
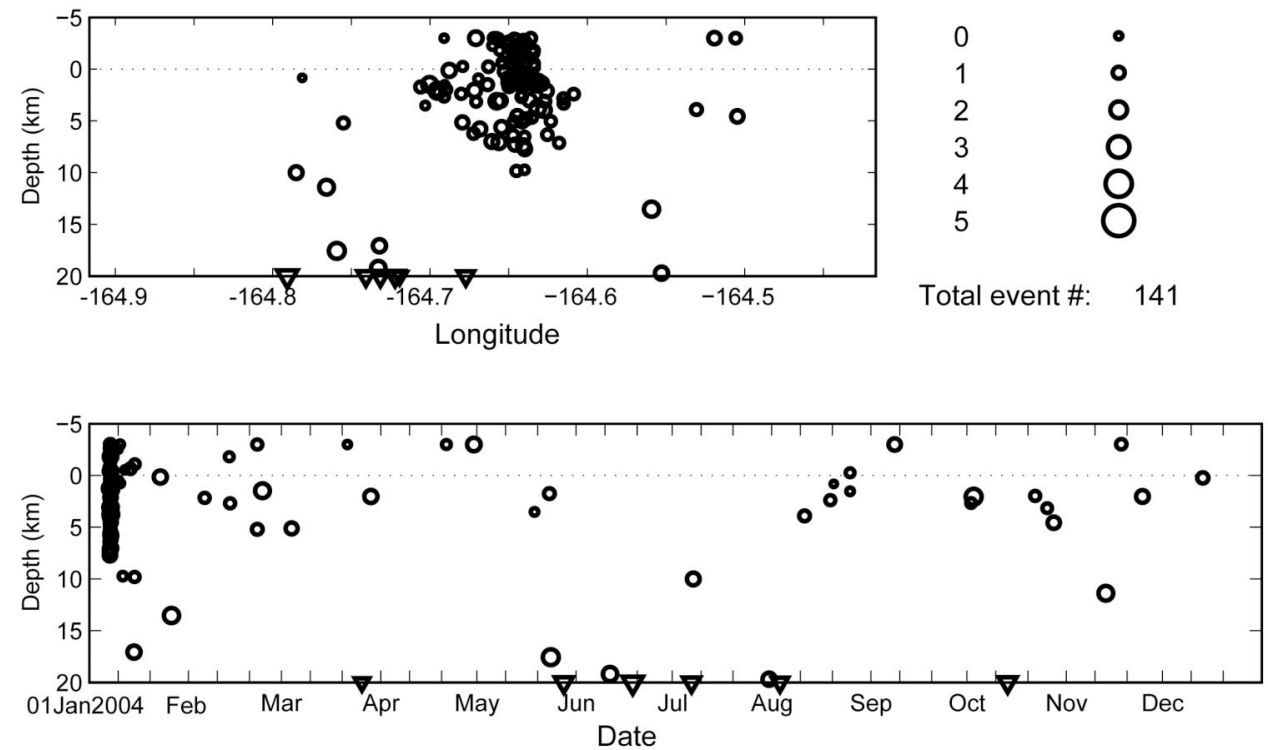

Figure A19. Summary plots of 141 earthquakes located near Westdahl Peak in 2004. Open circles show hypocenter locations shallower than $20 \mathrm{~km}$ and open triangles show hypocenters with depths of $20 \mathrm{~km}$ and deeper. Hypocenter symbols are scaled with magnitude. Seismograph stations are shown by open squares and labeled by station code. (See Appendix B for station information). Solid triangles are used to show volcanic centers and closed squares are used to show other points of interest. 

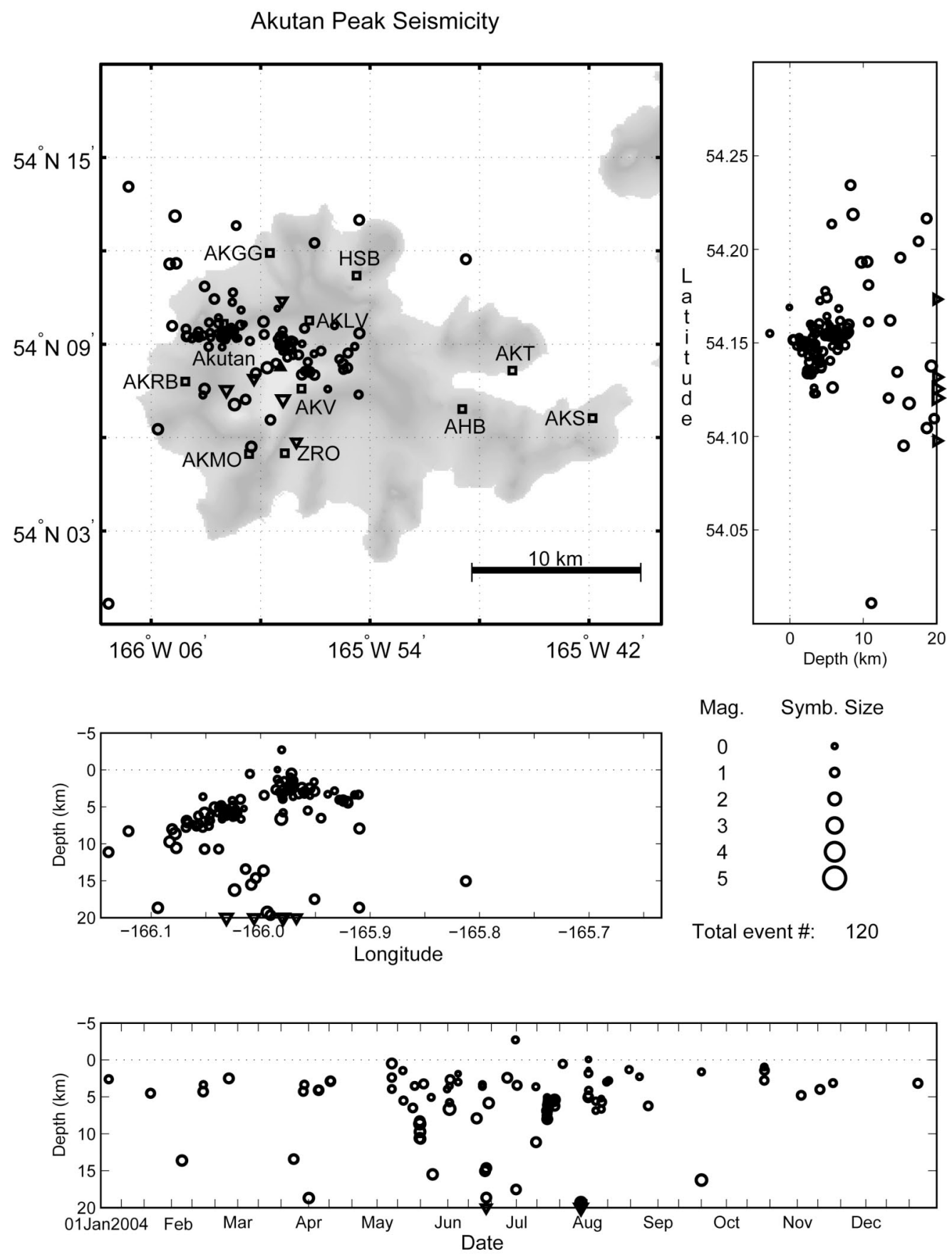

Figure A20. Summary plots of 120 earthquakes located near Akutan Peak in 2004. Open circles show hypocenter locations shallower than $20 \mathrm{~km}$ and open triangles show hypocenters with depths of $20 \mathrm{~km}$ and deeper. Hypocenter symbols are scaled with magnitude. Seismograph stations are shown by open squares and labeled by station code. (See Appendix B for station information). Solid triangles are used to show volcanic centers and closed squares are used to show other points of interest. 
Makushin Volcano Seismicity
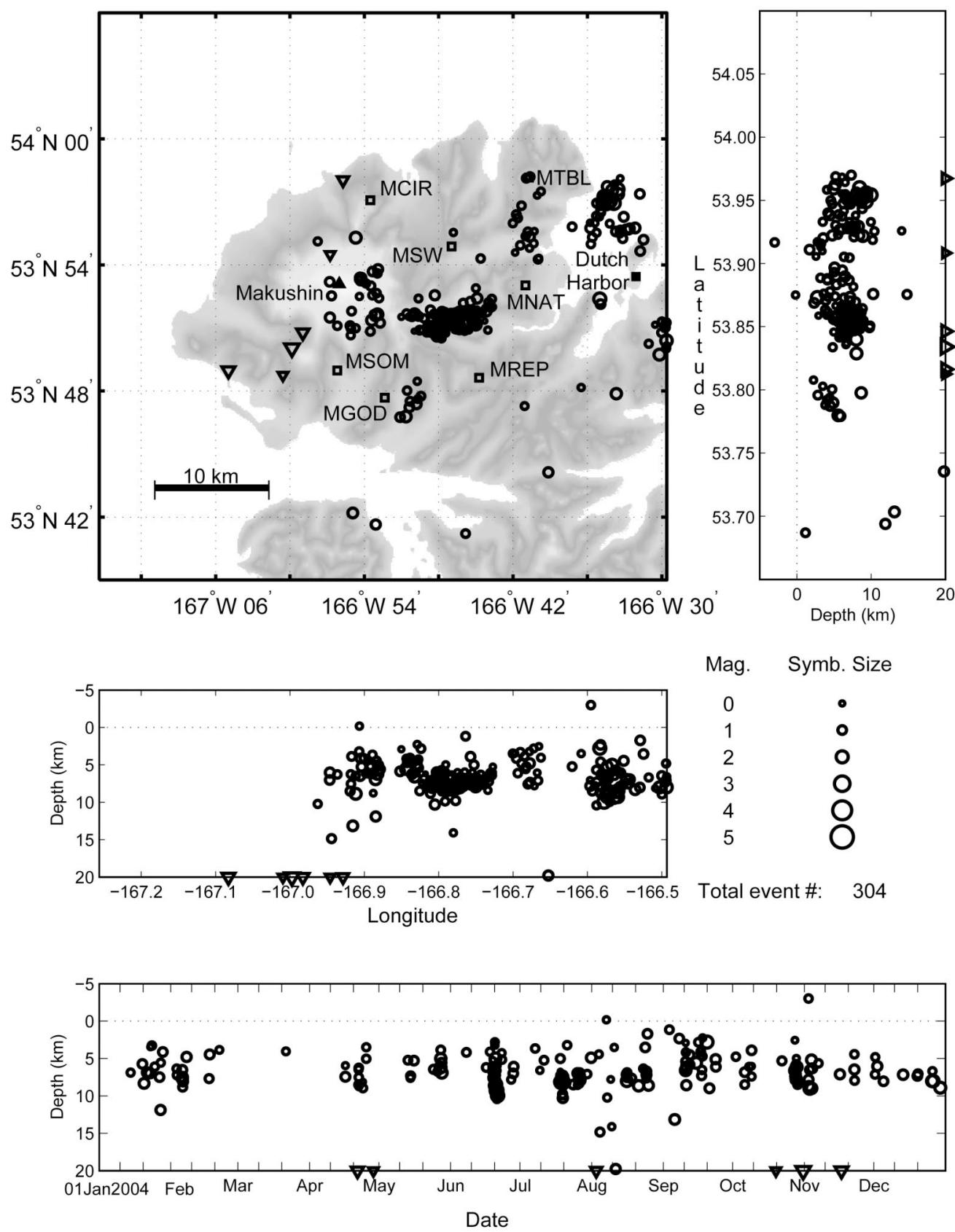

Figure A21. Summary plots of 304 earthquakes located near Makushin Volcano in 2004. Open circles show hypocenter locations shallower than $20 \mathrm{~km}$ and open triangles show hypocenters with depths of $20 \mathrm{~km}$ and deeper. Hypocenter symbols are scaled with magnitude. Seismograph stations are shown by open squares and labeled by station code. (See Appendix B for station information). Solid triangles are used to show volcanic centers and closed squares are used to show other points of interest. 

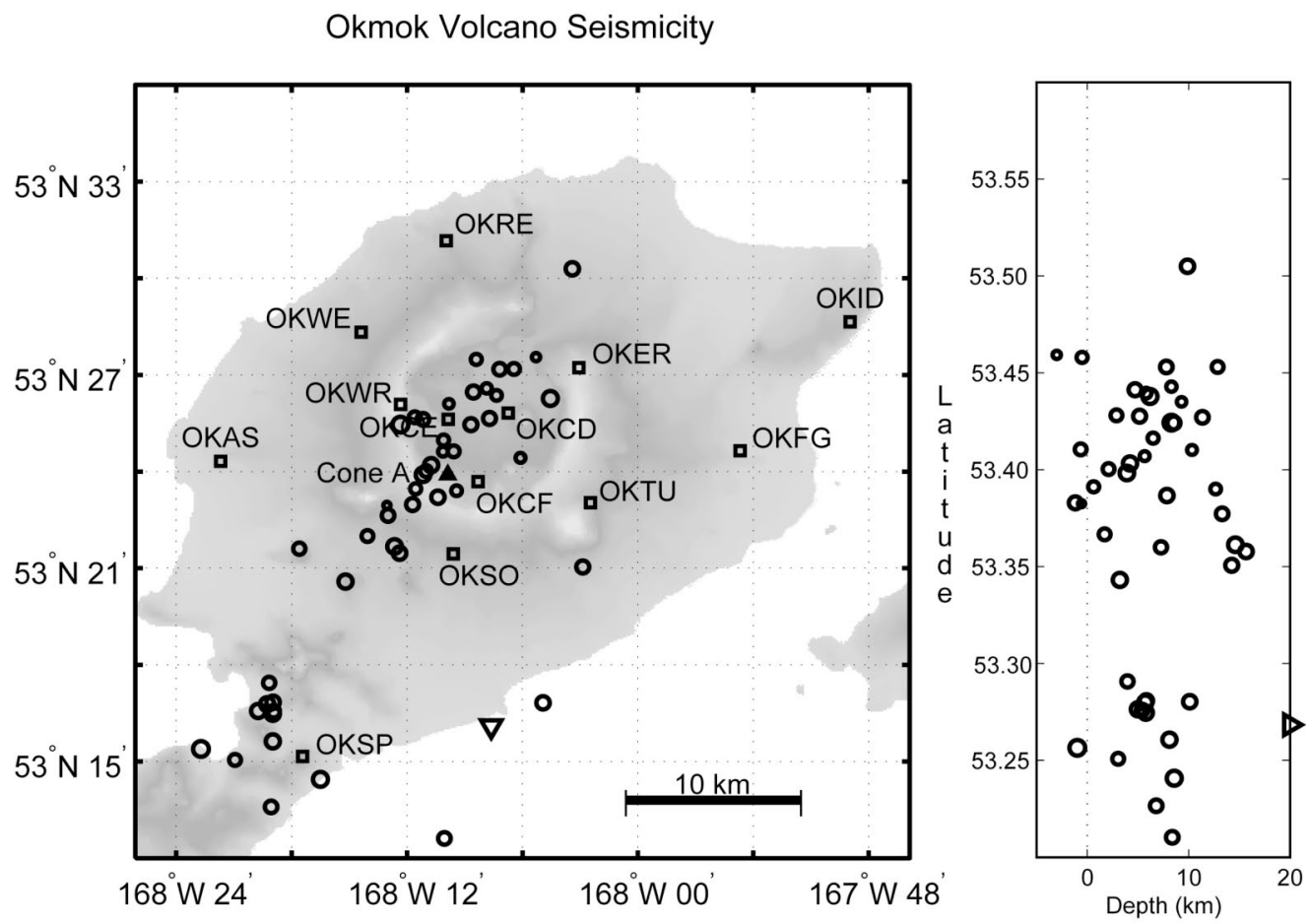

Mag. Symb. Size
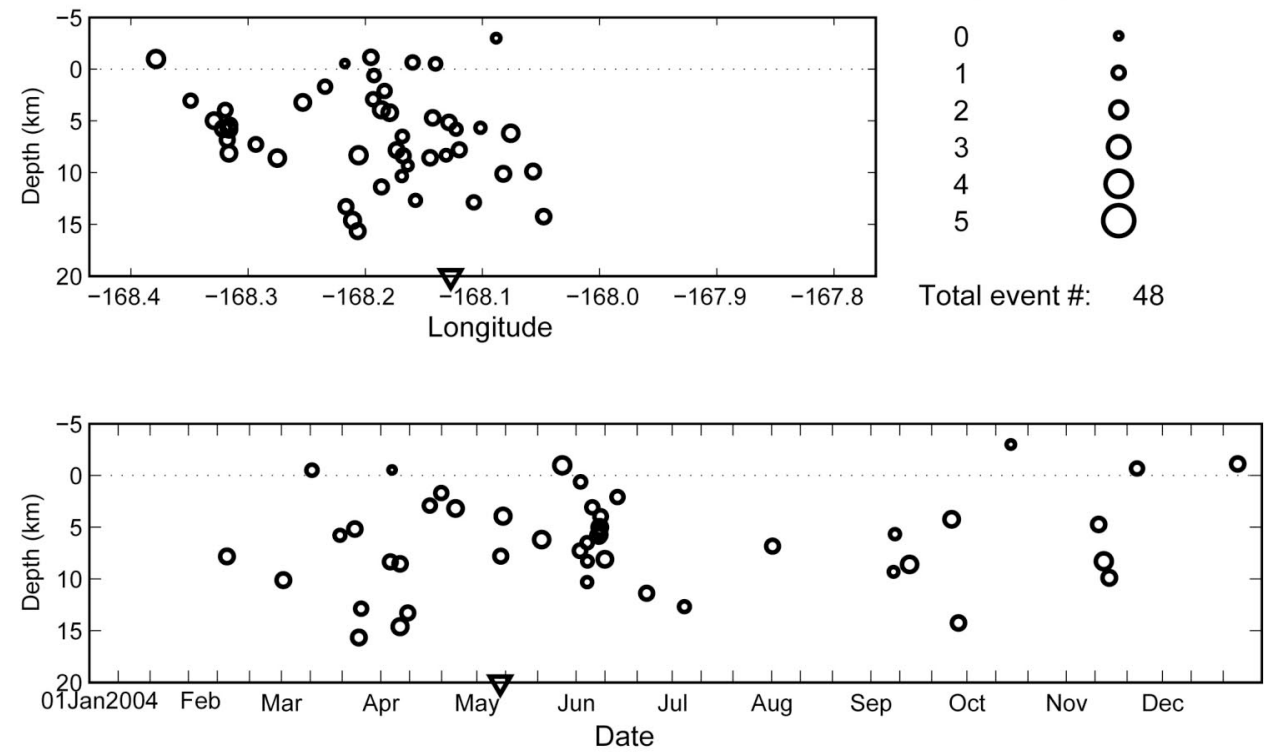

Figure A22. Summary plots of 48 earthquakes located near Okmok Caldera in 2004. Open circles show hypocenter locations shallower than $20 \mathrm{~km}$ and open triangles show hypocenters with depths of $20 \mathrm{~km}$ and deeper. Hypocenter symbols are scaled with magnitude. Seismograph stations are shown by open squares and labeled by station code. (See Appendix B for station information). Solid triangles are used to show volcanic centers and closed squares are used to show other points of interest. 

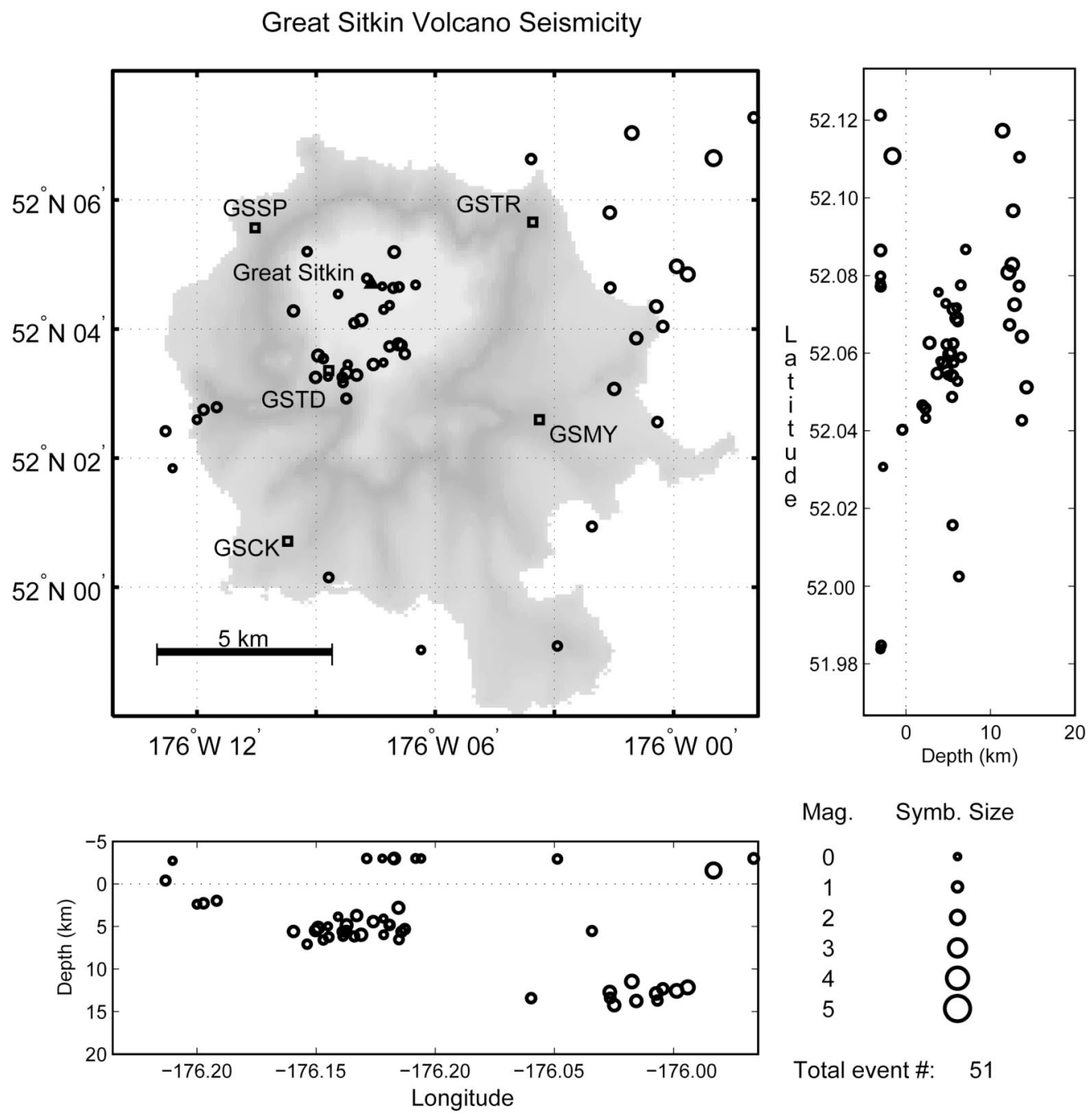

Mag. Symb. Size
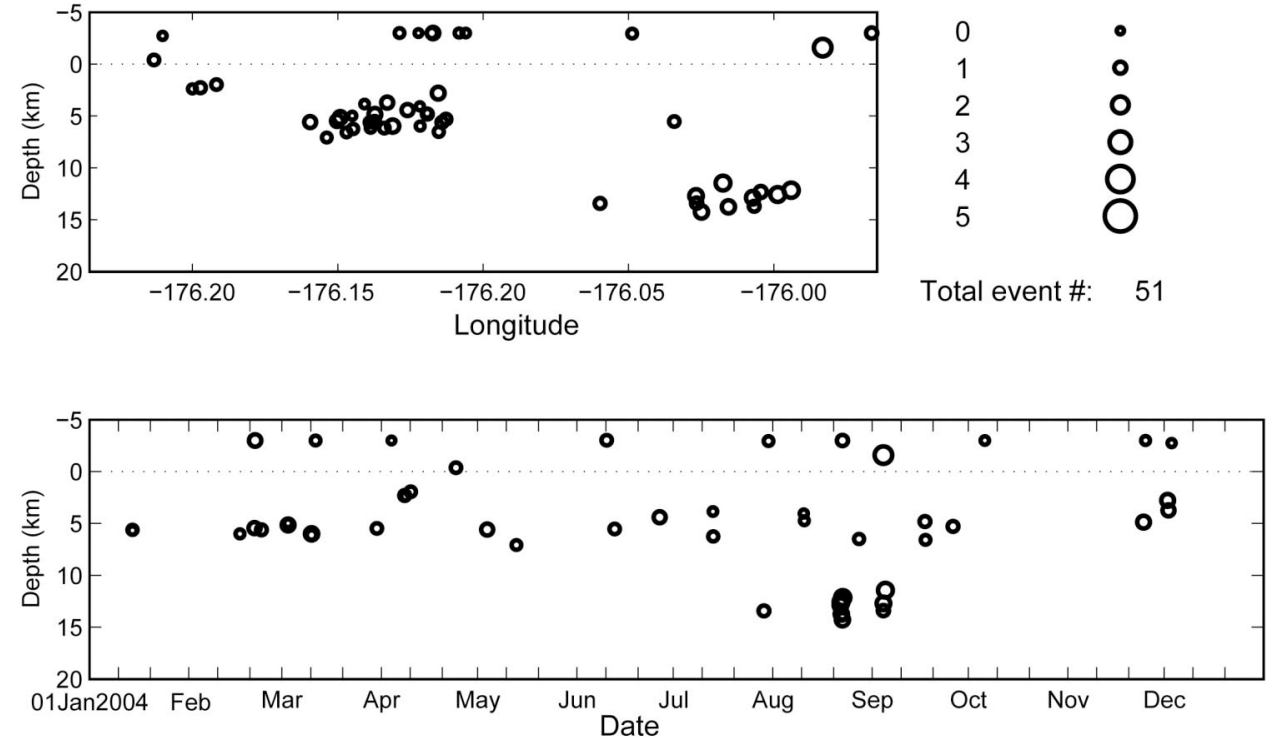

Figure A23. Summary plots of 51 earthquakes located near Great Sitkin Volcano in 2004. Open circles scaled with magnitude show hypocenter locations. Seismograph stations are shown by open squares and labeled by station code. (See Appendix B for station information). Solid triangles are used to show volcanic centers and closed squares are used to show other points of interest. 
Kanaga Volcano Seismicity
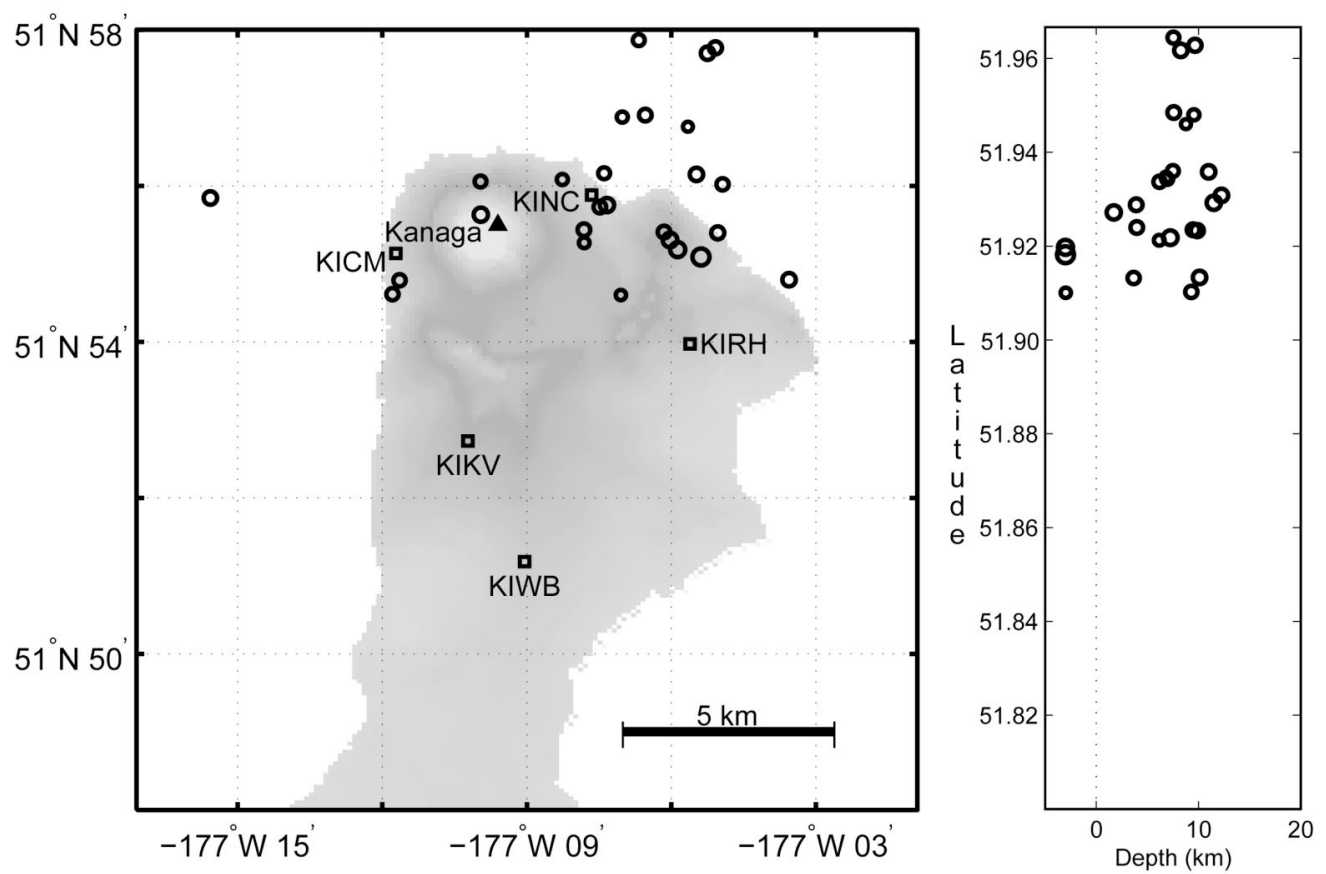

Mag. Symb. Size
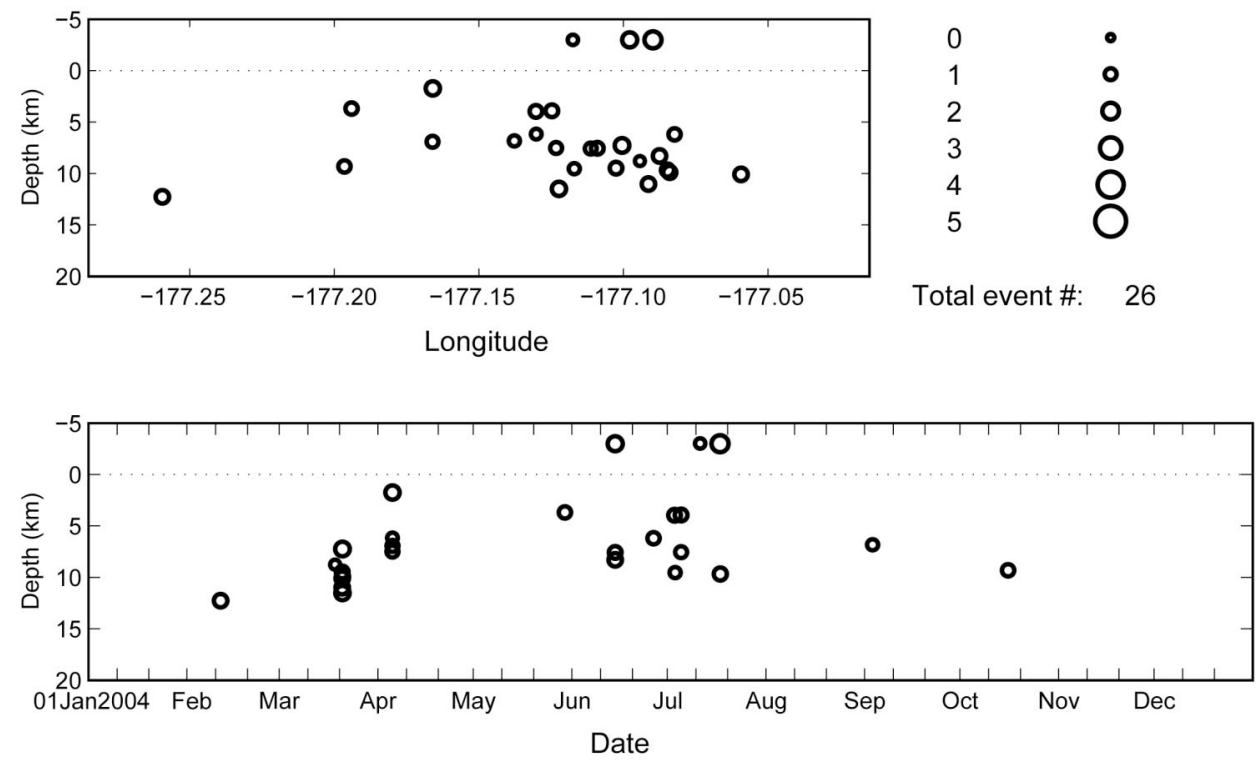

Figure A24. Summary plots of 26 earthquakes located near Kanaga Volcano in 2004. Open circles scaled with magnitude show hypocenter locations. Seismograph stations are shown by open squares and labeled by station code. (See Appendix B for station information). Solid triangles are used to show volcanic centers and closed squares are used to show other points of interest. 
Tanaga Volcano Seismicity
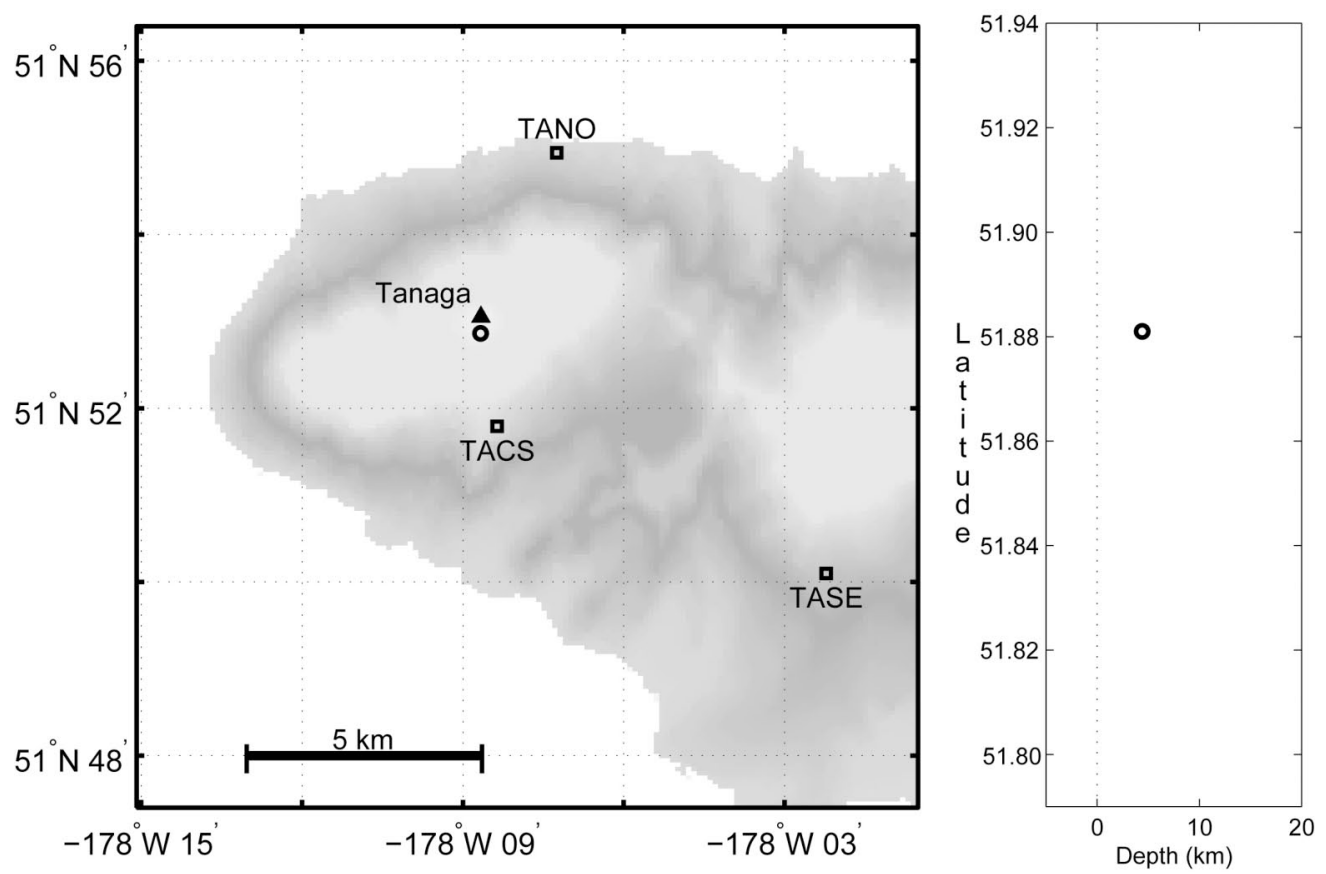

Mag. Symb. Size
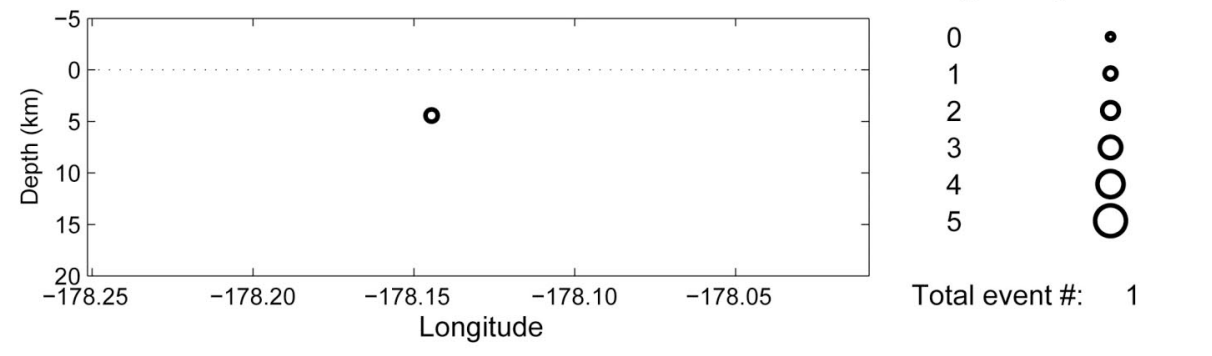

Total event \#: 1

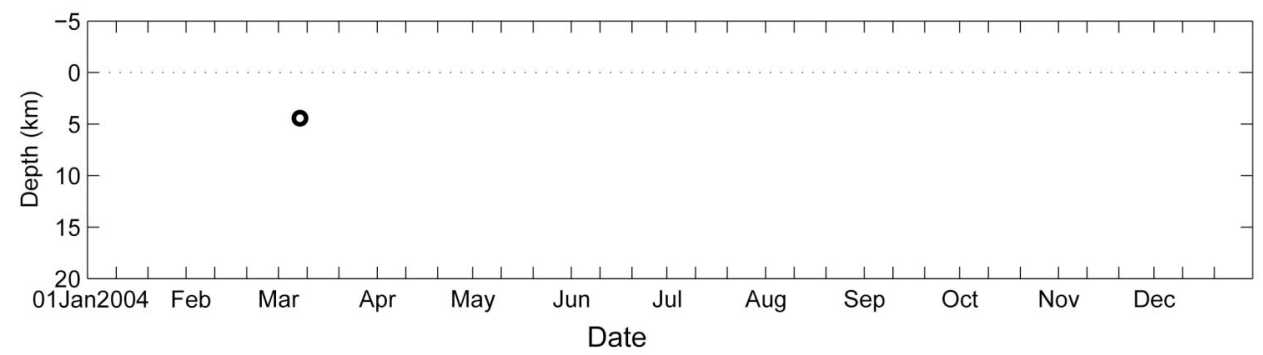

Figure A25. Summary plots of one earthquake located near Tanaga Volcano in 2004. Open circles scaled with magnitude show hypocenter locations. Seismograph stations are shown by open squares and labeled by station code. (See Appendix B for station information). Solid triangles are used to show volcanic centers and closed squares are used to show other points of interest. 
Gareloi Volcano Seismicity
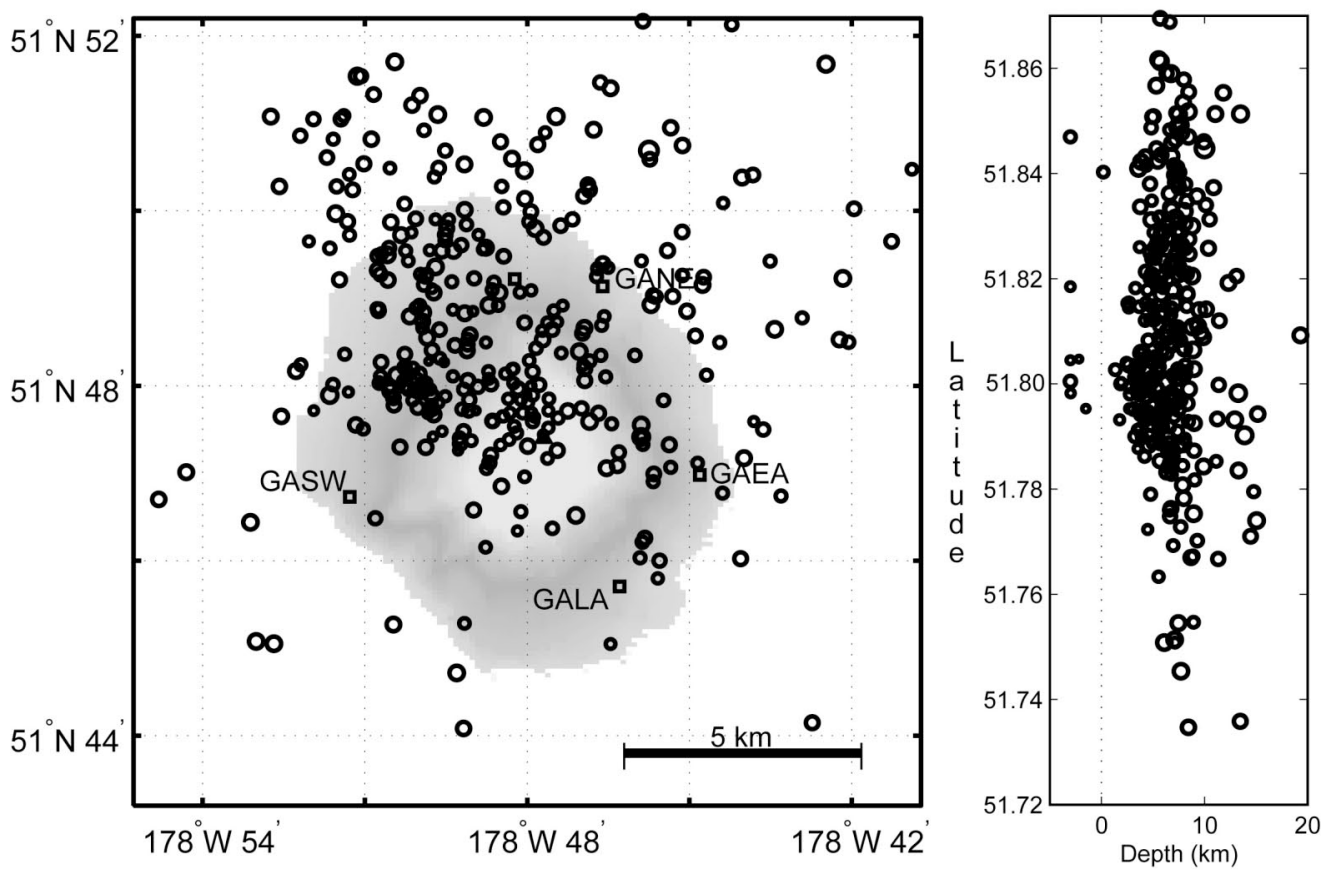

Mag. Symb. Size
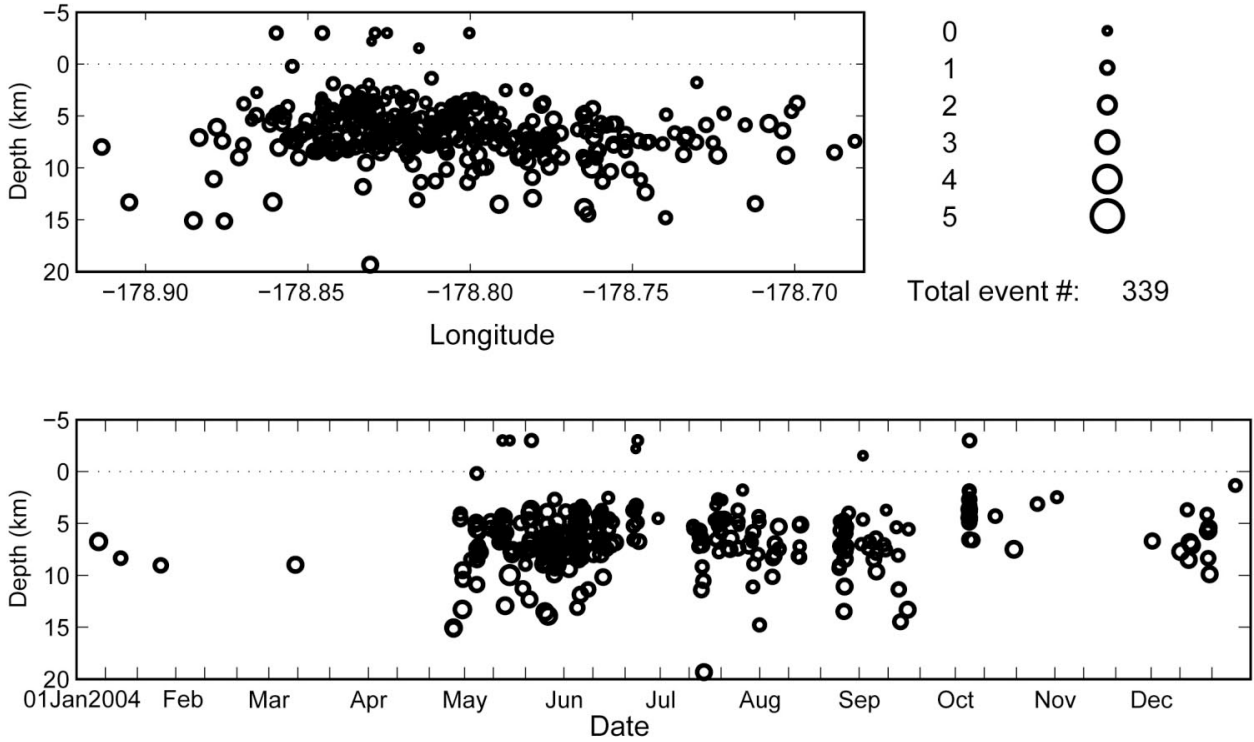

Figure A26. Summary plots of 339 earthquakes located near Mount Gareloi in 2004. Open circles scaled with magnitude show hypocenter locations. Seismograph stations are shown by open squares and labeled by station code. (See Appendix B for station information). Solid triangles are used to show volcanic centers and closed squares are used to show other points of interest. 


\section{Appendix B: Parameters for AVO seismograph stations (datum NAD27)}

$\underline{\text { Station }}$ Latitude (N) Longitude (W) Elevation (m) Seismometer Station open date

\begin{tabular}{llllll}
\multicolumn{7}{c}{ Akutan Peak subnet (11 stations - 23 components) } & & \\
AHB & 5406.916 & 16548.943 & 447 & L-4 & $1996 / 07 / 24$ \\
AKGG $^{B}$ & 5411.930 & 16559.495 & 326 & CMG-6TD & $2003 / 06 / 27$ \\
AKLV $^{B}$ & 5409.762 & 16557.336 & 551 & CMG-6TD & $2003 / 07 / 02$ \\
AKMO $^{B}$ & 5405.471 & 16600.634 & 277 & CMG-6TD & $2003 / 06 / 25$ \\
AKRB $^{B}$ & 5407.803 & 16604.125 & 334 & CMG-6TD & $2003 / 06 / 29$ \\
AKS $^{3}$ & 5406.624 & 16541.803 & 213 & L-22 & $1996 / 07 / 24$ \\
AKT $^{B}$ & 5408.15 & 16546.2 & 12 & CMG-40T & $1996 / 03 / 18$ \\
$A K V$ & 5407.571 & 16557.763 & 863 & L-4 & $1996 / 07 / 24$ \\
$H S B$ & 5411.205 & 16554.743 & 497 & L-4 & $1996 / 07 / 24$ \\
LVA & 5409.655 & 16602.025 & 457 & L-4 & $1996 / 07 / 24$ \\
ZRO & 5405.494 & 16558.678 & 446 & L-4 & $1996 / 07 / 24$
\end{tabular}

Aniakchak Crater subnet (6 stations - 8 components)

ANNE $\quad 5654.763 \quad 15803.534 \quad 705$

ANNW $\quad 5657.986 \quad 15812.895 \quad 816$

$\begin{array}{llll}\text { ANON }^{3} & 5655.188 & 15810.293 & 445\end{array}$

ANPB $\quad 5648.141 \quad 15816.847 \quad 658$

$\begin{array}{llll}\text { ANPK } & 5650.499 & 15807.572 & 972\end{array}$

$\begin{array}{llll}\text { AZAC } & 5653.727 & 15813.841 & 1057\end{array}$

$\begin{array}{ll}\text { L-4 } & 1997 / 07 / 18 \\ \text { L-4 } & 1997 / 07 / 18 \\ \text { L-22 } & 2000 / 07 / 10 \\ \text { L-4 } & 1997 / 07 / 18 \\ \text { L-4 } & 1997 / 07 / 18 \\ \text { L-4 } & 2003 / 07 / 12\end{array}$

Augustine Volcano subnet (8 stations - 13 components)

$\begin{array}{lllrlr}\text { AUE } & 5922.308 & 15322.504 & 168 & \text { S-13 } & 1980 / 10 / 29 \\ \text { AUH } & 5921.833 & 15326.591 & 890 & \text { S-13 } & 1978 / 12 / 01 \\ \text { AUI }^{3} & 5920.11 & 15325.66 & 293 & \text { S-13 } & 1978 / 04 / 06 \\ \text { AUL } & 5922.937 & 15326.142 & 360 & \text { S-13,CMG-40T } & 1978 / 08 / 27 \\ \text { AUP } & 5921.805 & 15325.210 & 1033 & \text { S-13 } & 1977 / 09 / 22 \\ \text { AUR } & 5921.766 & 15325.876 & 1225 & \text { L-4 } & 1995 / 11 / 01 \\ \text { AUS } & 5921.599 & 15325.840 & 1226 & \text { L-4 } & 1990 / 09 / 01 \\ \text { AUW } & 5922.205 & 15328.249 & 276 & \text { S-13 } & 1976 / 10 / 17\end{array}$

Mount Dutton subnet (5 stations - 5 components)

$\begin{array}{llllll}\text { BLDY } & 5511.670 & 16247.018 & 259 & \text { L-4 } & 1996 / 07 / 11 \\ \text { DOL } & 5508.960 & 16151.683 & 442 & \text { L-4 } & 1996 / 07 / 11 \\ \text { DRR3 } & 5458.014 & 16215.665 & 457 & \text { L-4 } & 1996 / 07 / 11 \\ \text { DT1 } & 5506.427 & 16216.859 & 198 & \text { L-4 } & 1991 / 06 / 21 \\ \text { DTN } & 5508.744 & 16215.419 & 396 & \text { S-13 } & 1988 / 07 / 16\end{array}$

Gareloi Volcano subnet (6 stations - 8 components)

$\begin{array}{lrrrll}\text { GAEA } & 5146.980 & 17844.810 & 326 & \text { L-4 } & 2003 / 08 / 30 \\ \text { GAKI } & 5133.267 & 17848.725 & 99 & \text { L-4 } & 2003 / 09 / 01 \\ \text { GALA } & 5145.704 & 17846.292 & 315 & \text { L-4 } & 2003 / 08 / 30 \\ \text { GANE } & 5149.135 & 17846.603 & 325 & \text { L-4 } & 2003 / 09 / 02 \\ \text { GANO } & 5149.220 & 17848.230 & 451 & \text { L-4 } & 2003 / 09 / 02 \\ \text { GASW }^{3} & 5146.731 & 17851.276 & 248 & \text { L-22 } & 2003 / 08 / 30\end{array}$


AVO Stations-continued.

$\underline{\text { Station }} \underline{\text { Latitude }(\mathrm{N})} \quad \underline{\text { Longitude }(\mathrm{W})}$ Elevation (m) $\underline{\text { Seismometer }} \underline{\text { Station open date }}$

Great Sitkin Volcano subnet (6 stations - 8 components)

$\begin{array}{llllll}\text { GSCK } & 5200.712 & 17609.718 & 384 & \text { L-4 } & 1999 / 09 / 15 \\ \text { GSIG } & 5159.181 & 17555.502 & 407 & \text { L-4 } & 1999 / 09 / 03 \\ \text { GSMY } & 5202.594 & 17603.376 & 418 & \text { L-4 } & 1999 / 09 / 03 \\ \text { GSSP } & 5205.566 & 17610.541 & 295 & \text { L-4 } & 1999 / 09 / 15 \\ \text { GSTD }^{3} & 5203.356 & 17608.685 & 873 & \text { L-22 } & 1999 / 09 / 03 \\ \text { GSTR } & 5205.655 & 17603.546 & 536 & \text { L-4 } & 1999 / 09 / 03\end{array}$

\begin{tabular}{|c|c|c|c|c|c|}
\hline \multicolumn{6}{|c|}{ Iliamna Volcano subnet (6 stations - 8 components) } \\
\hline ILI & 6004.877 & 15257.502 & 771 & L-4 & $1987 / 09 / 15$ \\
\hline ILS & 5957.454 & 15304.083 & 1125 & S-13 & $1996 / 08 / 28$ \\
\hline ILW & 6003.585 & 15308.222 & 1646 & S-13 & $1994 / 09 / 09$ \\
\hline INE & 6003.65 & 15303.75 & 1585 & S-13 & $1990 / 08 / 29$ \\
\hline $\mathrm{IVE}^{3}$ & 6001.014 & 15300.981 & 1173 & S-13,L-22 & $1996 / 09 / 19$ \\
\hline IVS & 6000.55 & 15304.85 & 2332 & L-4 & $1990 / 08 / 29$ \\
\hline
\end{tabular}

Kanaga Volcano subnet (6 stations - 6 components)

$\begin{array}{llllll}\text { KICM } & 5155.136 & 17711.718 & 183 & \text { L-4 } & 1999 / 09 / 15 \\ \text { KIKV } & 5152.730 & 17710.223 & 411 & \text { L-4 } & 1999 / 09 / 15 \\ \text { KIMD } & 5145.697 & 17714.093 & 183 & \text { L-4 } & 1999 / 09 / 15 \\ \text { KINC } & 5155.884 & 17707.657 & 198 & \text { L-4 } & 1999 / 09 / 15 \\ \text { KIRH } & 5153.976 & 17705.611 & 309 & \text { L-4 } & 1999 / 09 / 03 \\ \text { KIWB } & 5151.183 & 17709.049 & 244 & \text { L-4 } & 1999 / 09 / 03\end{array}$

\begin{tabular}{|c|c|c|c|c|c|}
\hline \multicolumn{6}{|c|}{ Katmai Volcanic Cluster subnet (18 stations - 24 components) } \\
\hline $\mathrm{ACH}^{3}$ & 5812.64 & 15519.56 & 960 & $\mathrm{~L}-22$ & $1996 / 07 / 25$ \\
\hline ANCK & 5811.93 & 15529.64 & 869 & L-4 & $1996 / 07 / 25$ \\
\hline CAHL & 5803.15 & 15518.09 & 807 & L-4 & $1996 / 07 / 25$ \\
\hline CNTC & 5815.87 & 15553.02 & 1158 & L-4 & $1996 / 07 / 25$ \\
\hline KABR & 5807.87 & 15458.15 & 884 & L-4 & $1998 / 08 / 12$ \\
\hline $\mathrm{KABU}^{\mathrm{B}}$ & 5816.225 & 15516.934 & 1065 & CMT-6TD & $2004 / 08 / 01$ \\
\hline KAHC & 5838.94 & 15500.36 & 1250 & L-4 & $1998 / 10 / 12$ \\
\hline KAHG & 5829.64 & 15432.78 & 923 & L-4 & $1998 / 10 / 12$ \\
\hline KAIC & 5829.10 & 15502.75 & 734 & L-4 & $1998 / 10 / 12$ \\
\hline $\mathrm{KAKN}^{\mathrm{B}}$ & 5817.819 & 15503.668 & 1049 & CMG-6TD & $2004 / 08 / 01$ \\
\hline $\mathrm{KAPH}^{3}$ & 5835.81 & 15420.81 & 907 & L-22 & $1998 / 10 / 12$ \\
\hline KARR & 5829.87 & 15442.20 & 610 & L-4 & $1998 / 10 / 12$ \\
\hline KAWH & 5823.02 & 15447.95 & 777 & L-4 & $1998 / 10 / 12$ \\
\hline KBM & 5816.50 & 15512.10 & 732 & L-4 & $1991 / 07 / 22$ \\
\hline $\mathrm{KCE}$ & 5814.60 & 15511.00 & 777 & L-4 & $1991 / 07 / 22$ \\
\hline $\mathrm{KCG}^{3}$ & 5818.457 & 15506.684 & 762 & L-22 & $1988 / 08 / 01$ \\
\hline KEL & 5826.401 & 15544.442 & 975 & L-4 & 1988/08/01 \\
\hline $\mathrm{KJL}$ & 5803.24 & 15534.39 & 792 & L-4 & $1996 / 07 / 25$ \\
\hline KVT & 5822.90 & 15517.70 & 457 & L-4 & $1988 / 08 / 01$ \\
\hline MGLS & 5808.06 & 15509.65 & 472 & L-4 & $1996 / 07 / 25$ \\
\hline
\end{tabular}


AVO Stations-continued.

$\underline{\text { Station }}$ Latitude (N) Longitude (W) Elevation (m) Seismometer $\underline{\text { Station open date }}$

\begin{tabular}{|c|c|c|c|c|c|}
\hline \multicolumn{6}{|c|}{ Korovin Volcano subnet ( 7 stations - 9 components) } \\
\hline KOFP & 5357.08 & 16653.51 & 662 & L-4 & $2004 / 07 / 02$ \\
\hline KOKL & 5347.68 & 16652.35 & 758 & L-4 & $2004 / 07 / 05$ \\
\hline $\mathrm{KOKV}^{3}$ & 5353.03 & 16641.00 & 776 & L-22 & $2004 / 07 / 05$ \\
\hline KONE & 5348.629 & 16644.736 & 253 & L-4 & $2004 / 07 / 10$ \\
\hline KONW & 5348.978 & 16656.187 & 334 & L-4 & $2004 / 07 / 04$ \\
\hline KOSE & 5354.88 & 16646.96 & 625 & L-4 & 2004/07/07 \\
\hline KOWE & 5358.16 & 16640.71 & 527 & L-4 & $2004 / 07 /$ \\
\hline
\end{tabular}

Makushin Volcano subnet (7 stations - 9 components)

$\begin{array}{llll}\text { MCIR } & 5357.086 & 16653.529 & 800\end{array}$

MGOD $\quad 5347.683 \quad 16652.561 \quad 650$

$\begin{array}{llll}\text { MNAT } & 5353.028 & 16641.016 & 397\end{array}$

$\begin{array}{llll}\text { MREP } & 5348.629 & 16644.736 & 785\end{array}$

MSOM $\quad 5348.978 \quad 16656.187 \quad 146$

$\begin{array}{llll}\text { MSW }^{3} & 5354.929 & 16647.186 & 418\end{array}$

MTBL $\quad 5358.136 \quad 16640.760 \quad 810$

Okmok Volcano subnet (12 stations - 18 components)

$\begin{array}{llll}\text { OKAS } & 5324.319 & 16821.686 & 270\end{array}$

$\begin{array}{llll}\text { OKCD }^{\mathrm{B}} & 5325.818 & 16806.737 & 459\end{array}$

$\begin{array}{llll}\mathrm{OKCE}^{\mathrm{B}} & 5325.622 & 16809.858 & 515\end{array}$

$\begin{array}{llll}\text { OKCF } & 5323.749 & 16808.175 & 685\end{array}$

$\begin{array}{llll}\text { OKER } & 5327.278 & 16802.960 & 956\end{array}$

$\begin{array}{llll}\text { OKFG }^{\mathrm{B}} & 5324.702 & 16754.568 & 201\end{array}$

$\begin{array}{llll}\text { OKID } & 5328.645 & 16748.972 & 437\end{array}$

$\begin{array}{llll}\text { OKRE } & 5331.215 & 16809.846 & 422\end{array}$

$\begin{array}{llll}\text { OKSO }^{\mathrm{B}} & 5321.447 & 16809.591 & 460\end{array}$

$\begin{array}{llll}\text { OKSP } & 5315.156 & 16817.431 & 608\end{array}$

$\begin{array}{llll}\text { OKTU } & 5323.035 & 16802.466 & 646\end{array}$

$\begin{array}{llll}\text { OKWE } & 5328.328 & 16814.388 & 445\end{array}$

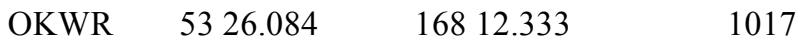

Pavlof Volcano subnet (7 stations - 9 components)

$\begin{array}{llllll}\text { BLHA } & 5542.227 & 16203.907 & 411 & \text { L-4 } & 1996 / 07 / 11 \\ \text { HAG } & 5519.068 & 16154.150 & 503 & \text { L-4 } & 1996 / 07 / 11 \\ \text { PN7A } & 5526.020 & 16159.713 & 838 & \text { L-4 } & 1996 / 07 / 11 \\ \text { PS1A } & 5525.321 & 16144.425 & 293 & \text { L-4 } & 1996 / 07 / 11 \\ \text { PS4A } & 5520.811 & 16151.233 & 322 & \text { L-4 } & 1996 / 07 / 11 \\ \text { PV6 }^{3} & 5527.217 & 16155.112 & 747 & \text { L-22 } & 1996 / 07 / 11 \\ \text { PVV } & 5522.438 & 16147.396 & 161 & \text { L-4 } & 1996 / 07 / 11\end{array}$

Mount Peulik subnet (7 stations - 9 components)

$\begin{array}{lllrll}\text { PLBL } & 5741.990 & 15649.131 & 461 & \text { L-4 } & 2004 / 08 / 01 \\ \text { PLK1 } & 5748.114 & 15636.433 & 78 & \text { L-4 } & 2004 / 08 / 01 \\ \text { PLK2 } & 5745.852 & 15619.458 & 401 & \text { L-4 } & 2004 / 08 / 01 \\ \text { PLK3 } & 5741.320 & 15616.044 & 494 & \text { L-22 } & 2004 / 08 / 01 \\ \text { PLK4 } & 5737.928 & 15621.464 & 1031 & \text { L-4 } & 2004 / 08 / 01 \\ \text { PLK5 } & 5759.864 & 15652.662 & 49 & \text { L-4 } & 2004 / 08 / 01 \\ \text { PLWL } & 5802.696 & 15620.479 & 585 & \text { L-4 } & 2004 / 08 / 01\end{array}$


AVO Stations-continued.

$\underline{\text { Station }} \underline{\text { Latitude }(\mathrm{N})} \quad \underline{\text { Longitude }(\mathrm{W})} \underline{\text { Elevation }(\mathrm{m})}$ Seismometer $\underline{\text { Station open date }}$

\begin{tabular}{|c|c|c|c|c|c|}
\hline \multicolumn{6}{|c|}{ Redoubt Volcano subnet ( 7 stations - 12 components) } \\
\hline DFR & 6035.514 & 15241.160 & 1090 & $\mathrm{~L}-4$ & $1988 / 08 / 15$ \\
\hline NCT & 6033.789 & 15255.568 & 1079 & $\mathrm{~L}-4$ & $1988 / 08 / 14$ \\
\hline $\mathrm{RDN}$ & 6031.377 & 15244.273 & 1400 & $\mathrm{~L}-4$ & $1988 / 08 / 13$ \\
\hline RDT & 6034.394 & 15224.315 & 930 & $\mathrm{~L}-4$ & $1971 / 08 / 09$ \\
\hline $\mathrm{RED}^{3}$ & 6025.192 & 15246.308 & 1064 & L-4 & $1990 / 08 / 30$ \\
\hline $\mathrm{REF}^{3 *}$ & 6029.35 & 15242.10 & 1801 & $\mathrm{~L}-22$ & $1992 / 07 / 27$ \\
\hline RSO & 6027.73 & 15245.23 & 1921 & L-4 & $1990 / 03 / 01$ \\
\hline
\end{tabular}

Shishaldin Volcano subnet (6 stations - 8 components)

$\begin{array}{llllll}\text { BRPK } & 5438.730 & 16344.449 & 393 & \text { L-4 } & 1997 / 07 / 27 \\ \text { ISNN } & 5449.937 & 16346.706 & 466 & \text { L-4 } & 1997 / 07 / 27 \\ \text { ISTK } & 5443.929 & 16342.376 & 704 & \text { L-4 } & 1997 / 07 / 27 \\ \text { SSLN } & 5448.709 & 16359.756 & 637 & \text { L-4 } & 1997 / 07 / 27 \\ \text { SSLS }^{3} & 5442.718 & 16359.926 & 817 & \text { L-22 } & 1997 / 07 / 27 \\ \text { SSLW } & 5446.307 & 16407.282 & 628 & \text { L-4 } & 1997 / 07 / 27\end{array}$

$\begin{array}{llllll}\text { SSLW } & 5446.307 & 16407.282 & 628 & \text { L-4 } & 1997 / 07 / 27\end{array}$

\section{Mount Spurr subnet (15 stations - 23 components)}

\begin{tabular}{|c|c|c|c|}
\hline BGL & 6116.012 & 15223.340 & 112 \\
\hline $\mathrm{BKG}$ & 6104.21 & 15215.76 & 10 \\
\hline CGL & 6118.46 & 15200.40 & \\
\hline CKL & 6111.782 & 15220.268 & \\
\hline CKN & 6113.44 & 15210.89 & \\
\hline CKT & 6112.05 & 15212.37 & \\
\hline $\mathrm{CP} 2$ & 6115.85 & 15214.51 & \\
\hline $\mathrm{CRP}^{3}$ & 6116.02 & 15209.33 & \\
\hline $\mathrm{NCG}$ & 6124.22 & 15209.40 & \\
\hline $\mathrm{SPBG}^{\mathrm{B}}$ & 6115.583 & 15222.194 & \\
\hline $\mathrm{SPCG}^{\mathrm{B}}$ & 6117.512 & 15201.228 & \\
\hline $\mathrm{SPCR}^{\mathrm{B}}$ & 6112.051 & 15212.409 & \\
\hline SPNW & 6120.826 & 15236.236 & \\
\hline SPU & 6110.90 & 15203.26 & \\
\hline SPWE & 6116.441 & 15233.410 & \\
\hline
\end{tabular}

$\begin{array}{ll}\text { L-4 } & 1989 / 08 / 13 \\ \text { L-4 } & 1991 / 07 / 01 \\ \text { L-4 } & 1981 / 09 / 22 \\ \text { L-4 } & 1989 / 08 / 05 \\ \text { L-4 } & 1991 / 08 / 19 \\ \text { L-4 } & 1992 / 09 / 16 \\ \text { L-4 } & 1992 / 10 / 23 \\ \text { L-4 } & 1981 / 08 / 26 \\ \text { L-4 } & 1989 / 08 / 06 \\ \text { CMG-6TD } & 2004 / 09 / 09 \\ \text { CMG-6TD } & 2004 / 09 / 08 \\ \text { CMG-6TD } & 2004 / 09 / 08 \\ \text { L-4 } & 2004 / 08 / 17 \\ \text { L-4 } & 1971 / 08 / 10 \\ \text { L-4 } & 2004 / 08 / 18\end{array}$

Tanaga Volcano subnet (6 stations - 8 components)

$\begin{array}{llllll}\text { TACS } & 5151.792 & 17808.363 & 918 & \mathrm{~L}-4 & 2003 / 08 / 28 \\ \text { TAFL } & 5145.396 & 17753.867 & 186 & \mathrm{~L}-4 & 2003 / 08 / 28 \\ \text { TAFP }^{3} & 5154.003 & 17758.997 & 440 & \mathrm{~L}-22 & 2003 / 08 / 27 \\ \text { TANO } & 5154.942 & 17807.249 & 269 & \mathrm{~L}-4 & 2003 / 08 / 24 \\ \text { TAPA } & 5148.932 & 17748.770 & 640 & \mathrm{~L}-4 & 2003 / 08 / 27 \\ \text { TASE } & 5150.099 & 17802.222 & 682 & \mathrm{~L}-4 & 2003 / 08 / 24\end{array}$

\begin{tabular}{|c|c|c|c|c|c|}
\hline \multicolumn{6}{|c|}{ Mount Veniaminof subnet (9 stations - 9 components) } \\
\hline $\mathrm{BPBC}$ & 5635.383 & 15827.153 & 584 & L-4 & $2002 / 10 / 03$ \\
\hline VNFG & 5617.140 & 15933.066 & 1068 & L-4 & $2002 / 02 / 06$ \\
\hline VNHG & 5613.267 & 15909.853 & 966 & L-4 & $2002 / 02 / 06$ \\
\hline VNKR & 5601.871 & 15922.068 & 620 & L-4 & $2002 / 02 / 06$ \\
\hline VNNF & 5617.022 & 15918.961 & 1153 & L-4 & $2002 / 06 / 20$ \\
\hline VNSG & 5607.549 & 15905.121 & 761 & L-4 & $2002 / 02 / 06$ \\
\hline VNSS & 5613.600 & 15927.290 & 1733 & L-4 & $2002 / 02 / 06$ \\
\hline VNSW & 5604.317 & 15933.508 & 716 & L-4 & $2002 / 06 / 20$ \\
\hline VNWF & 5609.104 & 15933.733 & 1095 & L-4 & $2002 / 02 / 06$ \\
\hline
\end{tabular}


AVO Stations-continued.

$\underline{\text { Station }} \underline{\text { Latitude }(\mathrm{N})}$ Longitude (W) Elevation (m) $\underline{\text { Seismometer }} \underline{\text { Station open date }}$

$\begin{array}{lcccll}\text { Westdahl Peak subnet (6 stations - 8 components) } & & & \\ \text { WESE } & 5428.389 & 16435.038 & 953 & \text { L-4 } & 1998 / 08 / 28 \\ \text { WESN } & 5434.600 & 16434.703 & 549 & \text { L-4 } & 1998 / 10 / 17 \\ \text { WESS }^{3} & 5428.828 & 16443.333 & 908 & \text { L-22 } & 1998 / 08 / 28 \\ \text { WFAR } & 5432.029 & 16446.567 & 640 & \text { L-4 } & 1998 / 08 / 28 \\ \text { WPOG } & 5435.837 & 16444.606 & 445 & \text { L-4 } & 1998 / 10 / 17 \\ \text { WTUG } & 5450.847 & 16423.117 & 636 & \text { L-4 } & 1998 / 10 / 17\end{array}$

\begin{tabular}{|c|c|c|c|c|c|}
\hline \multicolumn{6}{|c|}{ Mount Wran } \\
\hline WACK $^{3}$ & 6159.178 & 14419.703 & 2280 & L-22 & $2000 / 07 / 3$ \\
\hline WANC & 6200.189 & $144 \quad 4.195$ & 4190 & L-4 & $2000 / 07 /$ \\
\hline WASW & 6155.692 & 14410.346 & 2196 & L-4 & $001 / 08$ \\
\hline WAZA & 6204.506 & $144 \quad 9.132$ & 2531 & L-4 & $2001 / 08 / 0$ \\
\hline
\end{tabular}

Regional stations (14 stations - 14 components)

$\begin{array}{llllll}\text { ADAG } & 5158.812 & 17636.104 & 286 & \text { L-4 } & 1999 / 09 / 15 \\ \text { BGM } & 5923.56 & 15513.76 & 625 & \text { L-4 } & 1978 / 09 / 08 \\ \text { BGR } & 6045.45 & 15225.06 & 985 & \text { L-4 } & 1991 / 07 / 01 \\ \text { CDD } & 5855.771 & 15338.558 & 622 & \text { S-13 } & 1981 / 08 / 17 \\ \text { CNP } & 5931.552 & 15114.088 & 564 & \text { L-4 } & 1983 / 07 / 01 \\ \text { ETKA } & 5151.712 & 17624.351 & 290 & \text { L-4 } & 1999 / 09 / 15 \\ \text { HOM } & 5939.50 & 15138.60 & 198 & \text { L-4 } & 1976 / 08 / 00 \\ \text { MMN } & 5911.11 & 15420.20 & 442 & \text { S-13 } & 1981 / 08 / 22 \\ \text { NNL } & 6002.66 & 15117.30 & 381 & \text { L-4 } & 1972 / 08 / 24 \\ \text { OPT } & 5939.192 & 15313.796 & 634 & \text { S-13 } & 1974 / 00 / 00 \\ \text { PDB } & 5947.27 & 15411.55 & 305 & \text { S-13 } & 1978 / 09 / 09 \\ \text { STLK } & 6129.926 & 15149.963 & 945 & \text { L-4 } & 1997 / 09 / 01 \\ \text { SYI } & 5836.60 & 15223.45 & 149 & \text { S- } 13 & 1990 / 08 / 27 \\ \text { XLV } & 5927.28 & 15140.30 & 320 & \text { S-13 } & 1987 / 09 / 16\end{array}$

Station Codes:

${ }^{3}$ Three-component short-period station

${ }^{\mathrm{B}}$ Three-component broadband station

${ }^{\mathrm{S}}$ Station also includes a single short-period vertical station

${ }^{*} \mathrm{REF}$ also has a low-gain vertical component.

Seismometer Codes:

CMG-40T: Guralp CMG-40T 60 second natural period broadband seismometer

CMG-6TD: Guralp CMG-6TD 30 second natural period broadband seismometer

L-4: $\quad$ Mark Products L4 one second natural period seismometer

L-22: $\quad$ Mark Products L22 0.5 second natural period seismometer

S-13: Teledyne Geotech S-13 one second natural period seismometer 
Appendix C: Figures showing the locations of the permanent AVO regional and volcano-specific seismograph stations. In all figures, closed triangles show volcanic centers and open squares show seismograph stations.

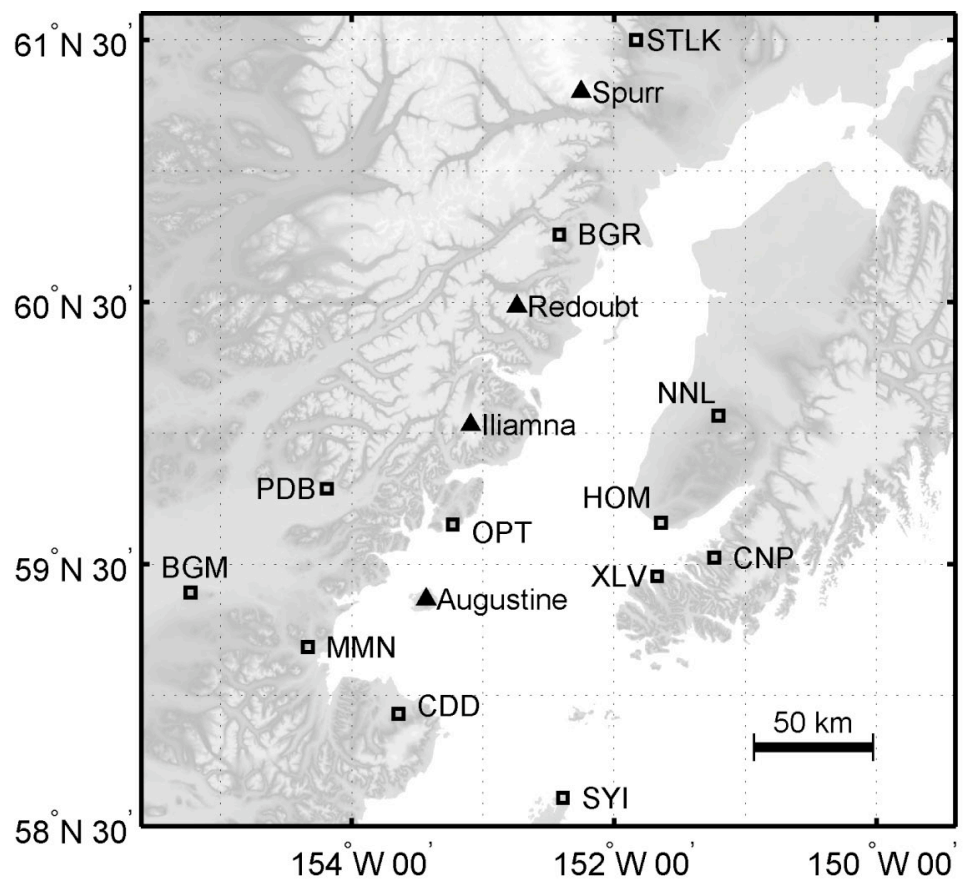

Figure C1. Regional AVO seismograph stations in Cook Inlet. Seismograph stations are shown by open squares. Closed triangles show volcanic centers.

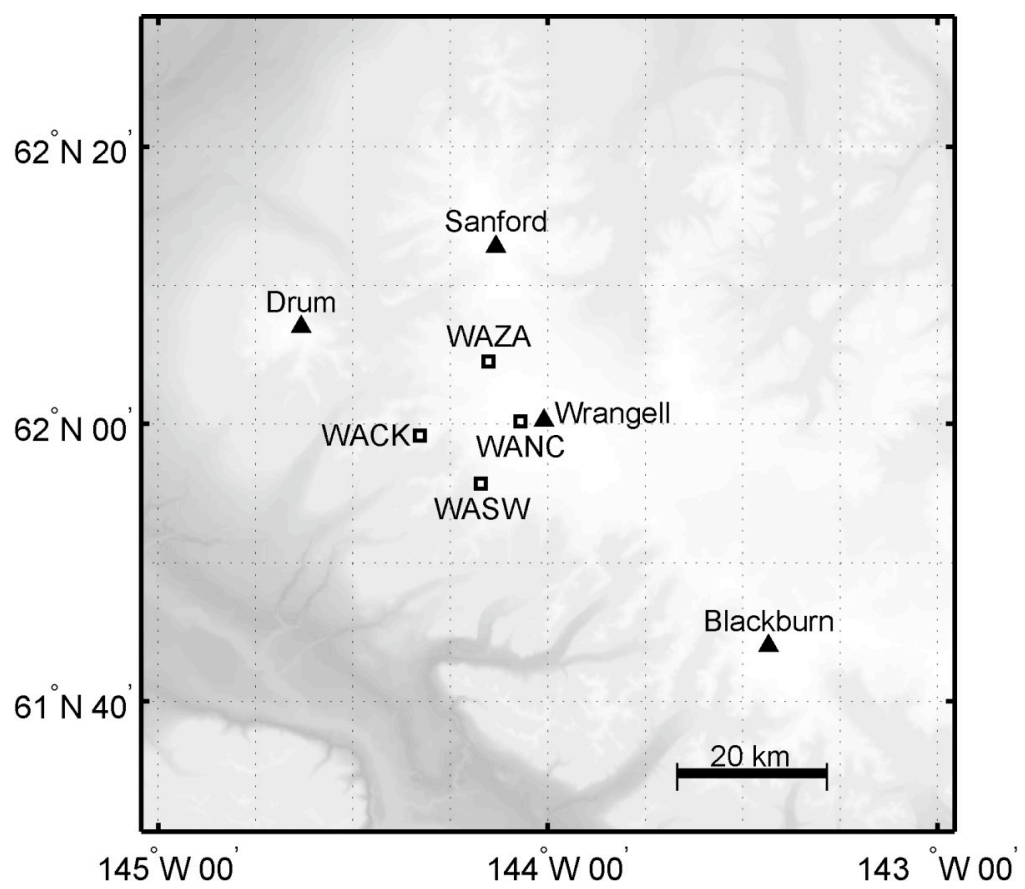

Figure C2. AVO seismograph stations near Mount Wrangell. Seismograph stations are shown by open squares. Closed triangles show volcanic centers. 


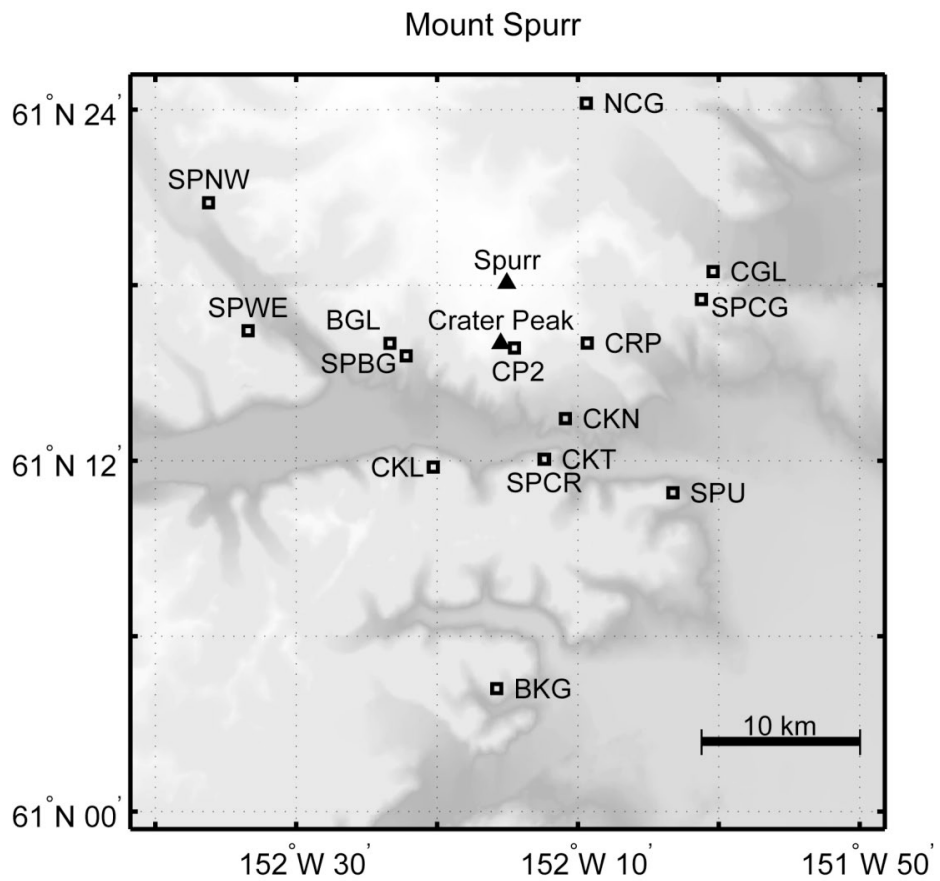

Figure C3. AVO seismograph stations near Mount Spurr. Seismograph stations are shown by open squares. Closed triangles show volcanic centers.

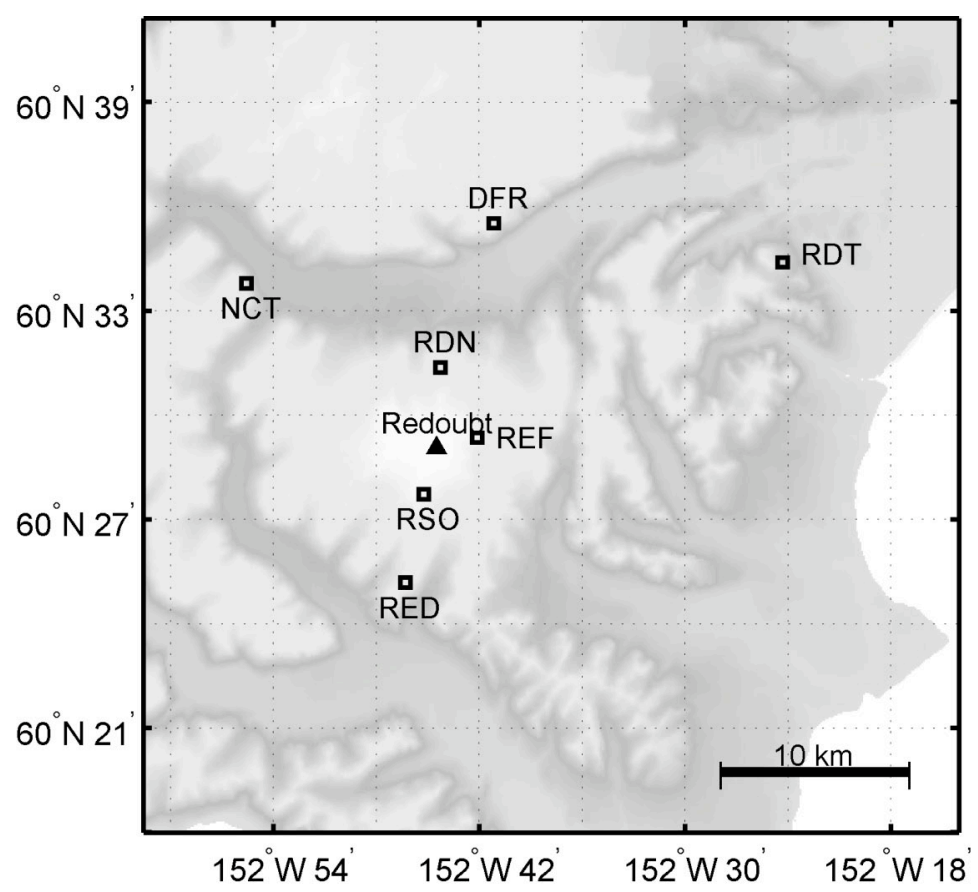

Figure C4. AVO seismograph stations near Redoubt Volcano. Seismograph stations are shown by open squares. Closed triangles show volcanic centers. 


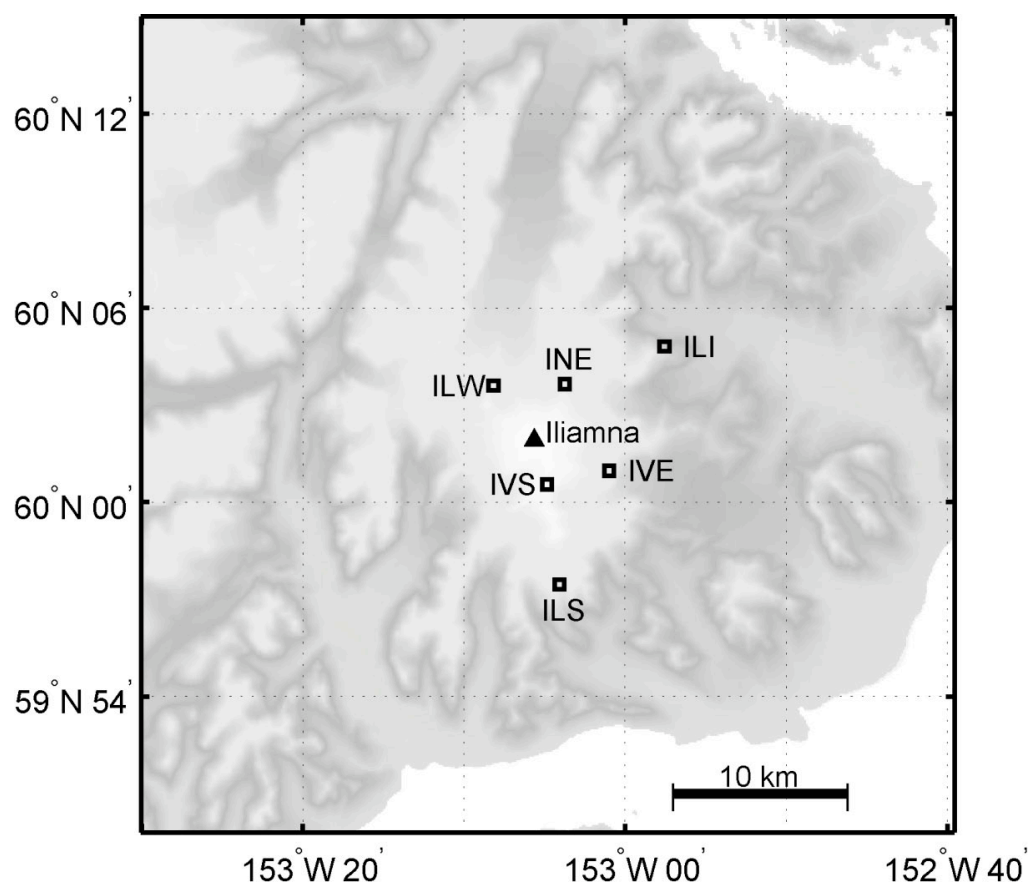

Figure C5. AVO seismograph stations near Iliamna Volcano. Seismograph stations are shown by open squares. Closed triangles show volcanic centers.

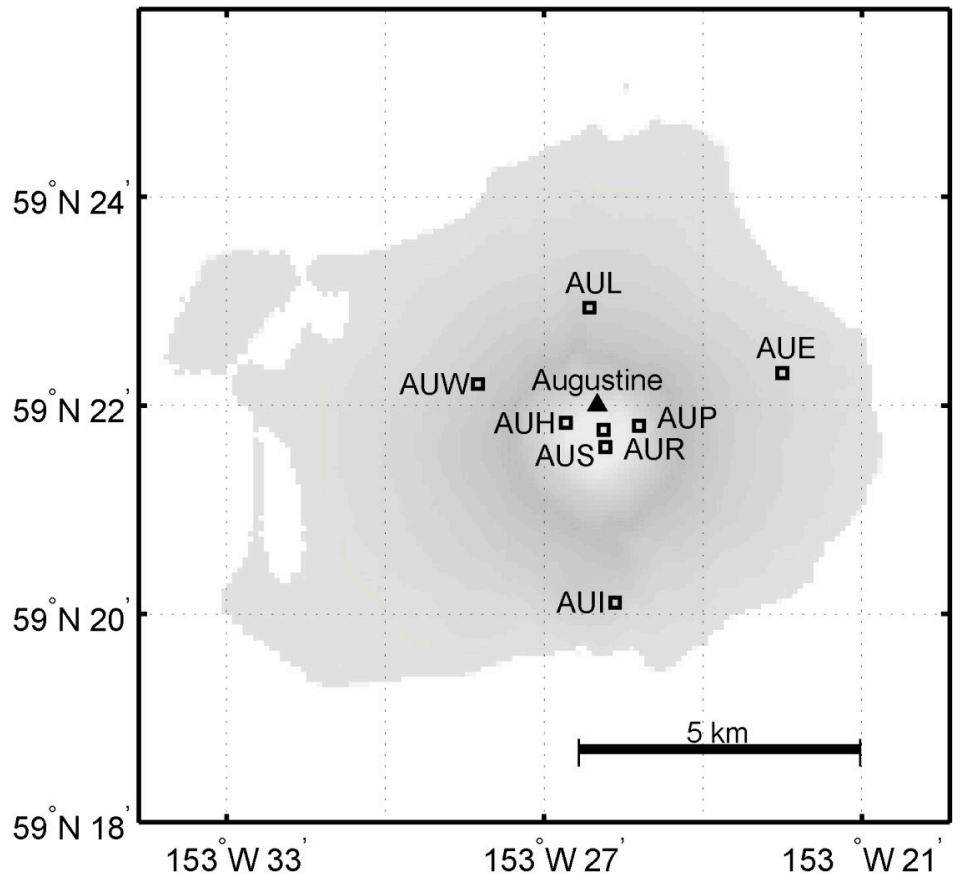

Figure C6. AVO seismograph stations near Augustine Volcano. Seismograph stations are shown by open squares. Closed triangles show volcanic centers. 


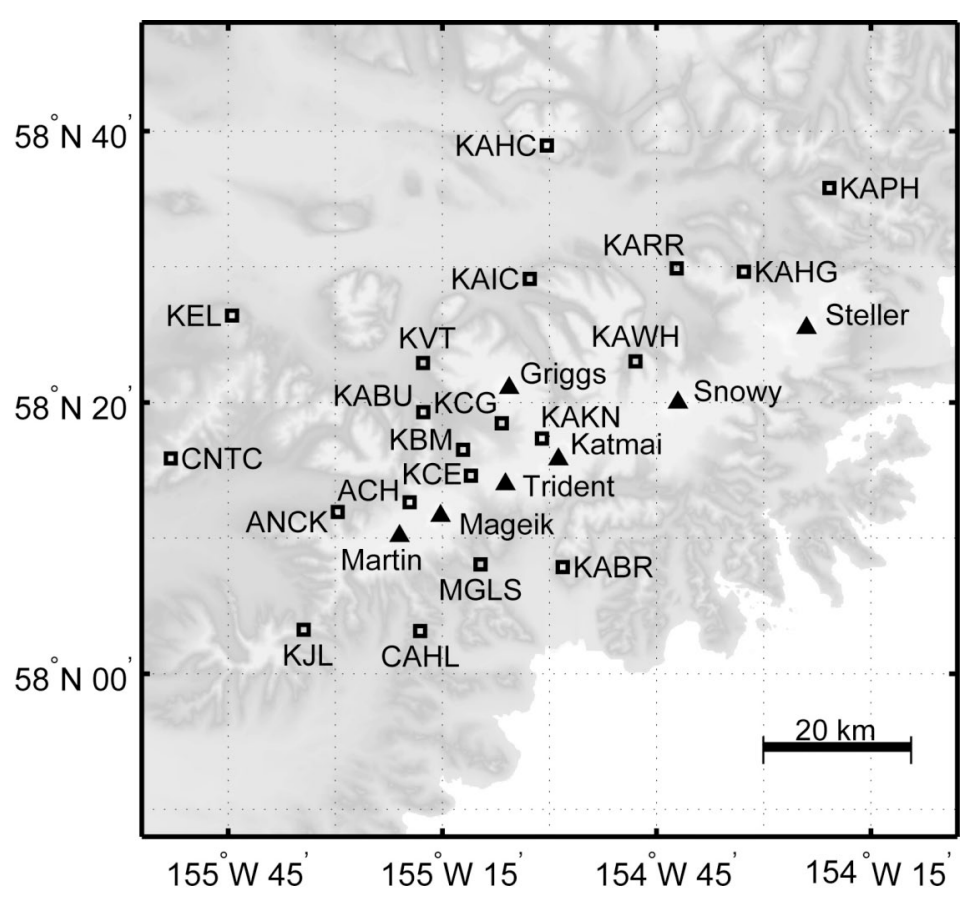

Figure C7. AVO seismograph stations near the Katmai volcanic cluster. Seismograph stations are shown by open squares. Closed triangles show volcanic centers.

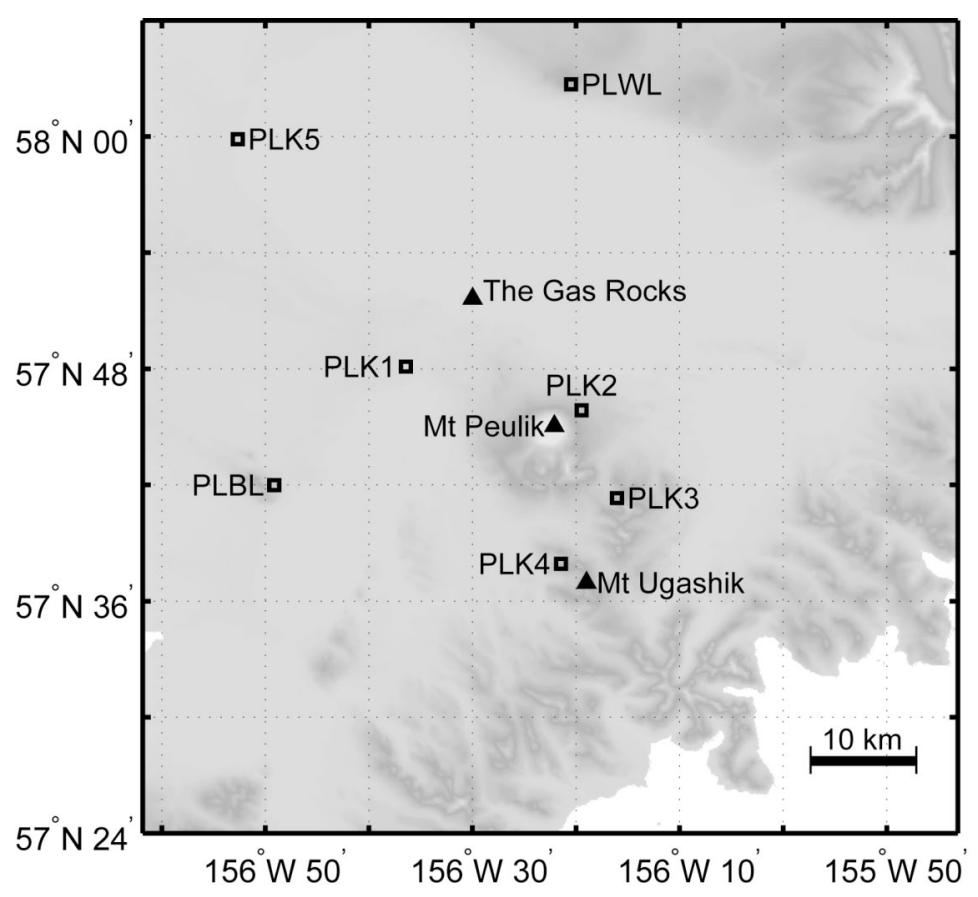

Figure C8. AVO seismograph stations near the Mount Peulik. Seismograph stations are shown by open squares. Closed triangles show volcanic centers. 


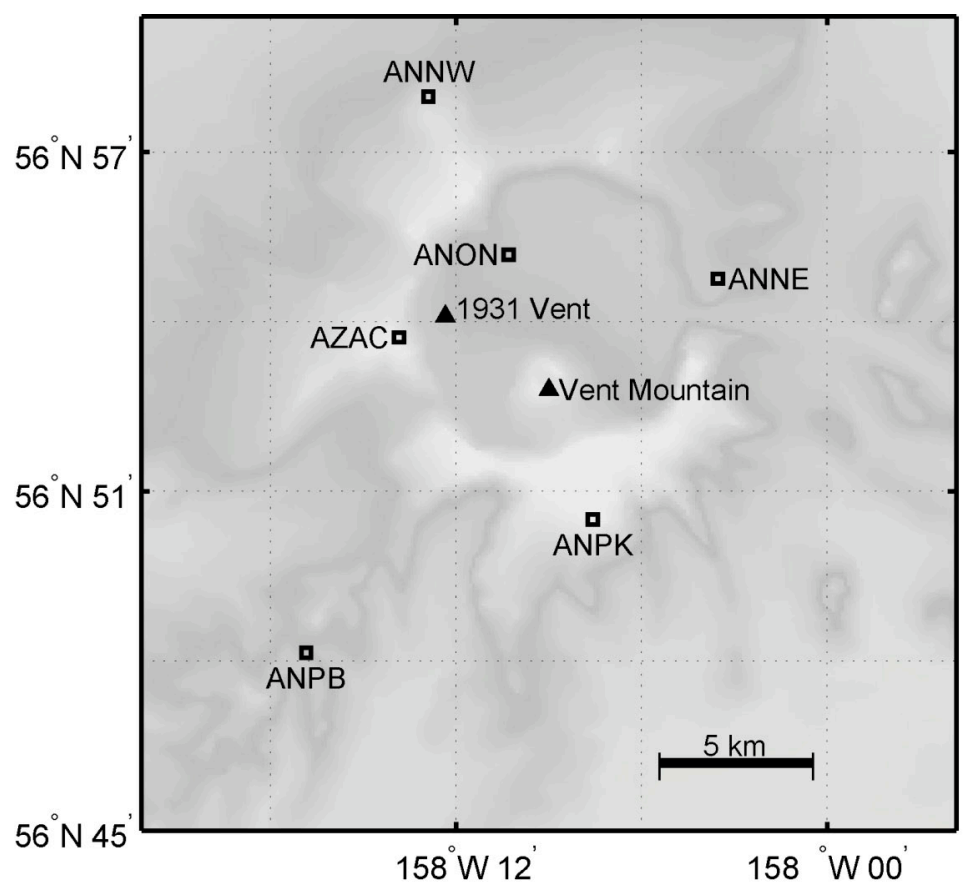

Figure C9. AVO seismograph stations near Aniakchak Crater. Seismograph stations are shown by open squares. Closed triangles show volcanic centers.

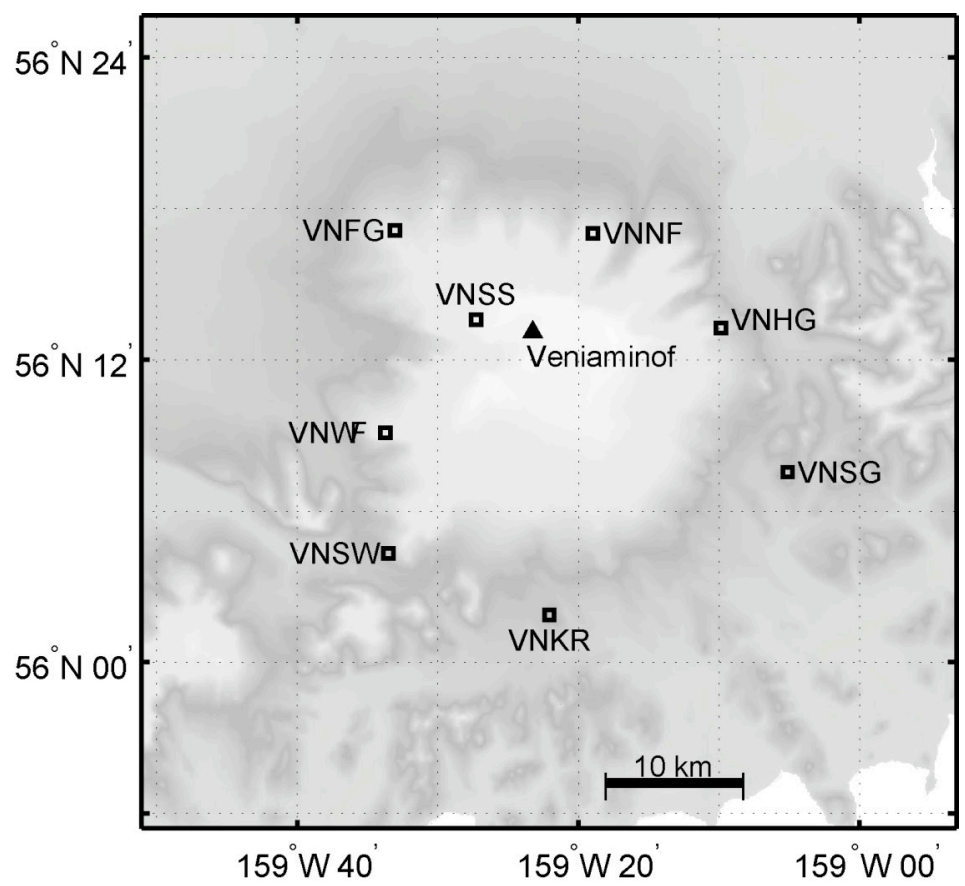

Figure C10. AVO seismograph stations near Mount Veniaminof. Seismograph station $\mathrm{BPBC}$ is not shown and is located $70 \mathrm{~km}$ northeast of Mount Veniaminof. Seismograph stations are shown by open squares. Closed triangles show volcanic centers. 


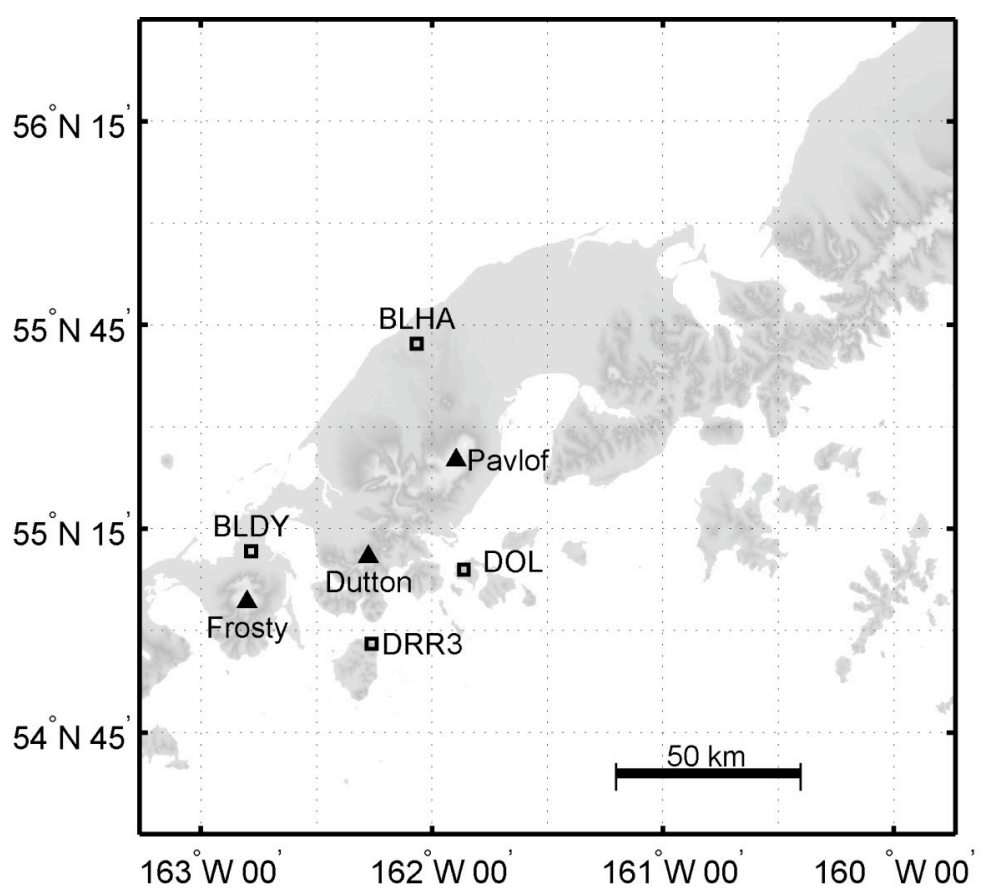

Figure C11. Regional AVO seismograph stations on the western end of the Alaska Peninsula. Seismograph stations are shown by open squares. Closed triangles show volcanic centers.

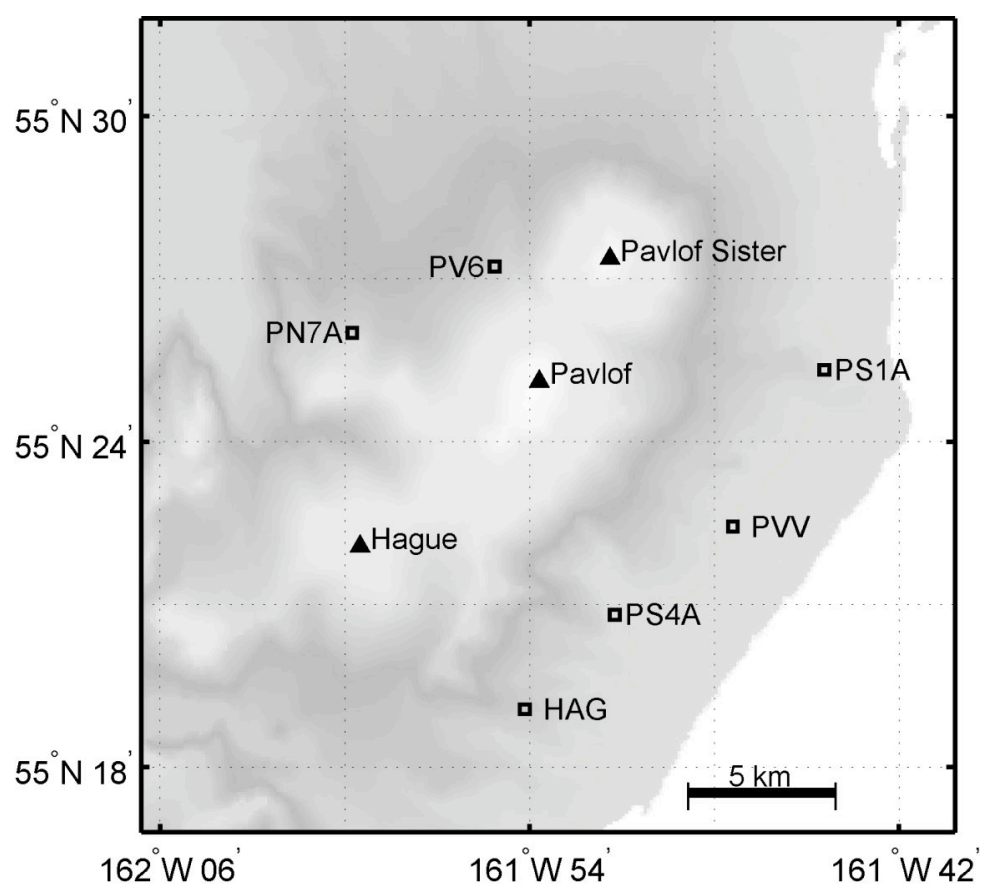

Figure C12. AVO seismograph stations near Pavlof Volcano. Seismograph stations are shown by open squares. Closed triangles show volcanic centers. 


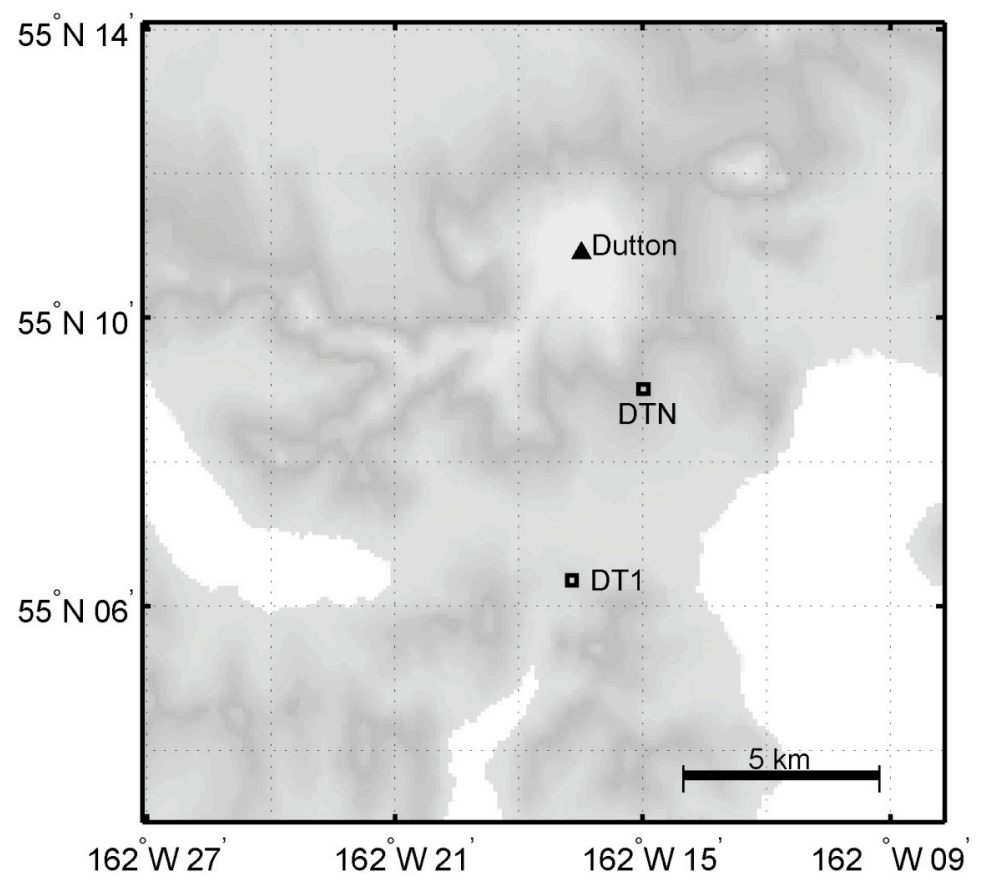

Figure C13. AVO seismograph stations near Mount Dutton. Seismograph stations are shown by open squares. Closed triangles show volcanic centers.

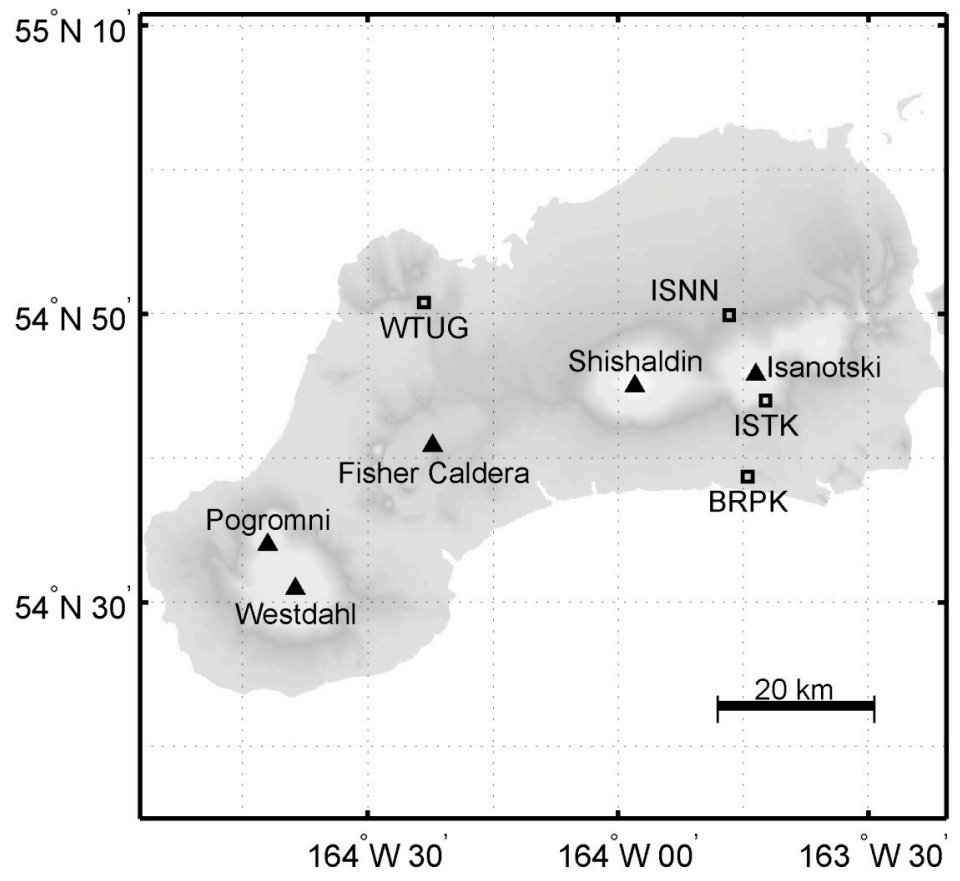

Figure C14. Regional AVO seismograph stations on Unimak Island. Seismograph stations are shown by open squares. Closed triangles show volcanic centers. 


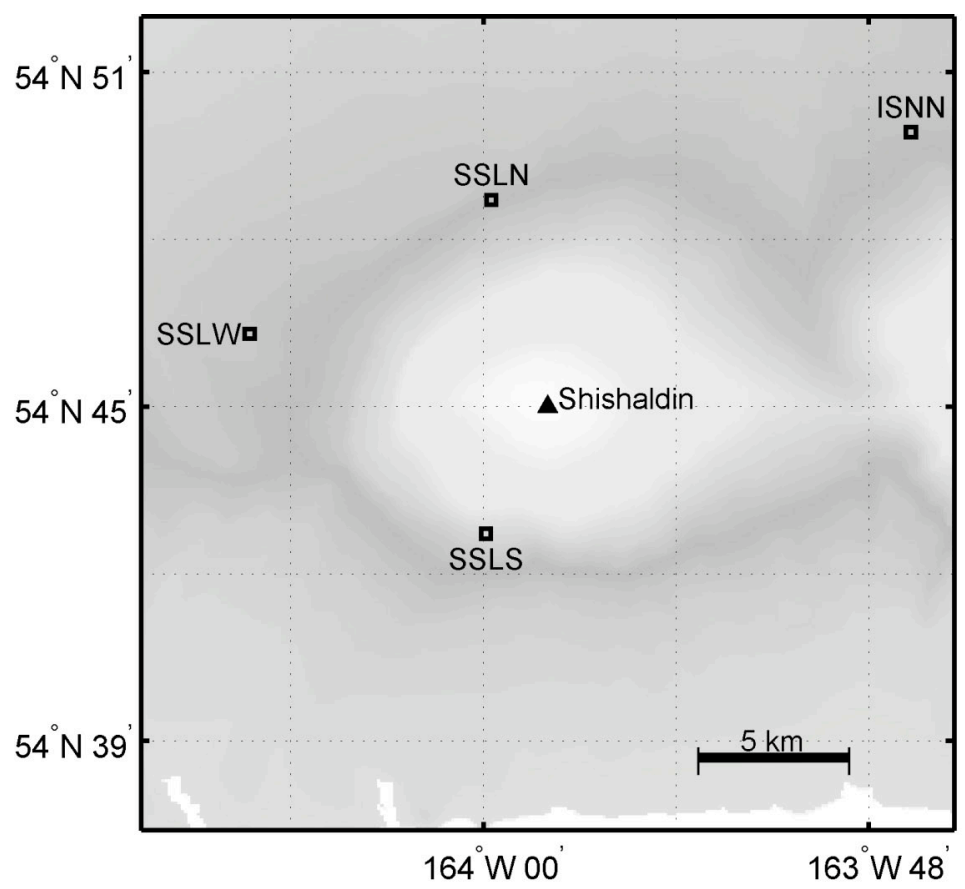

Figure C15. AVO seismograph stations near Shishaldin Volcano. Seismograph stations are shown by open squares. Closed triangles show volcanic centers.

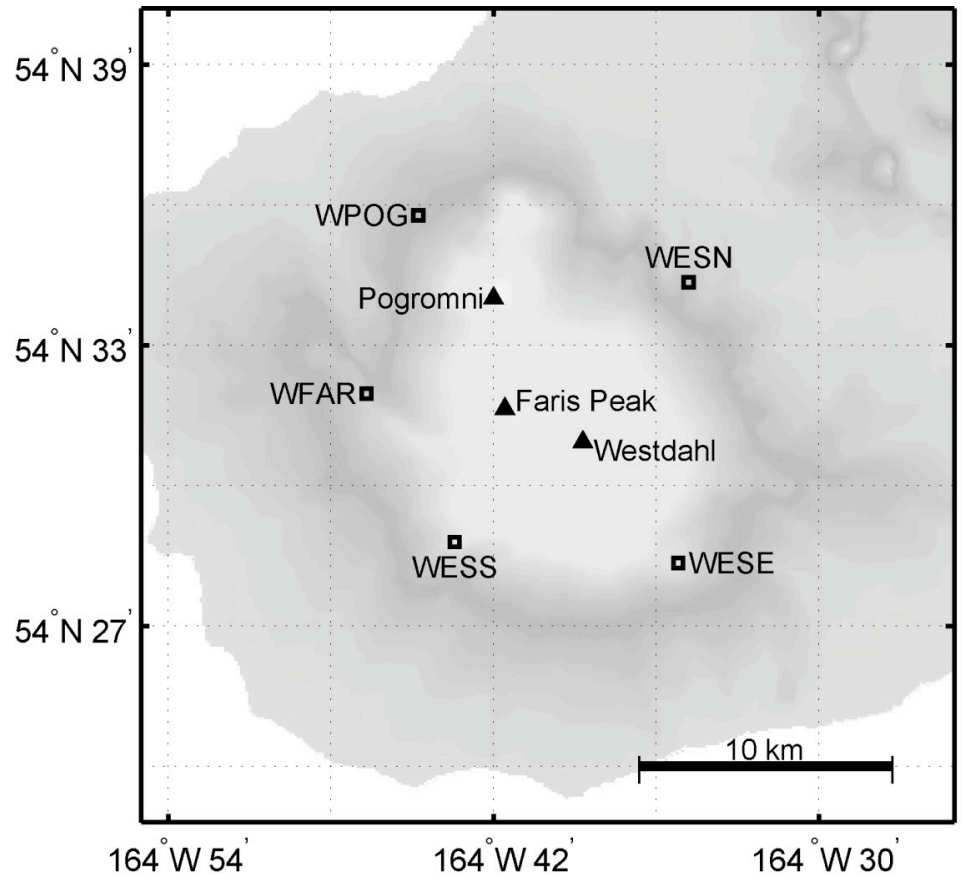

Figure C16. AVO seismograph stations near Westdahl Peak. Seismograph stations are shown by open squares. Closed triangles show volcanic centers. 


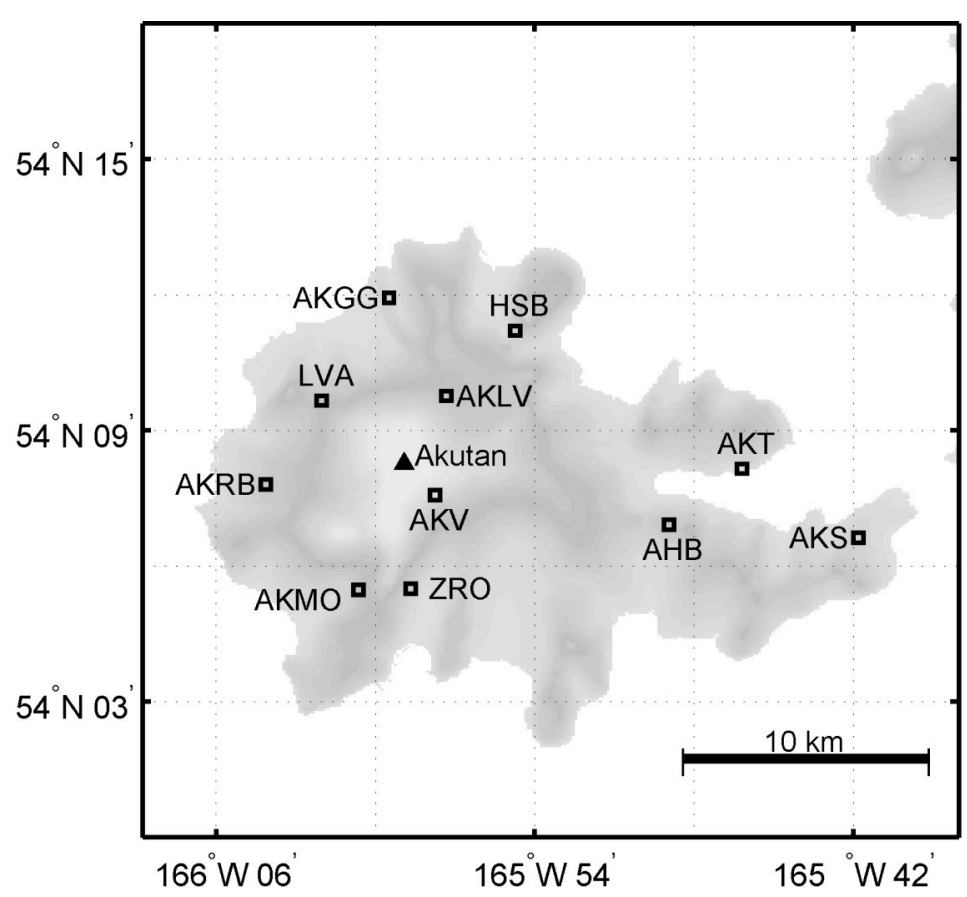

Figure C17. AVO seismograph stations near Akutan Peak. Seismograph stations are shown by open squares. Closed triangles show volcanic centers.

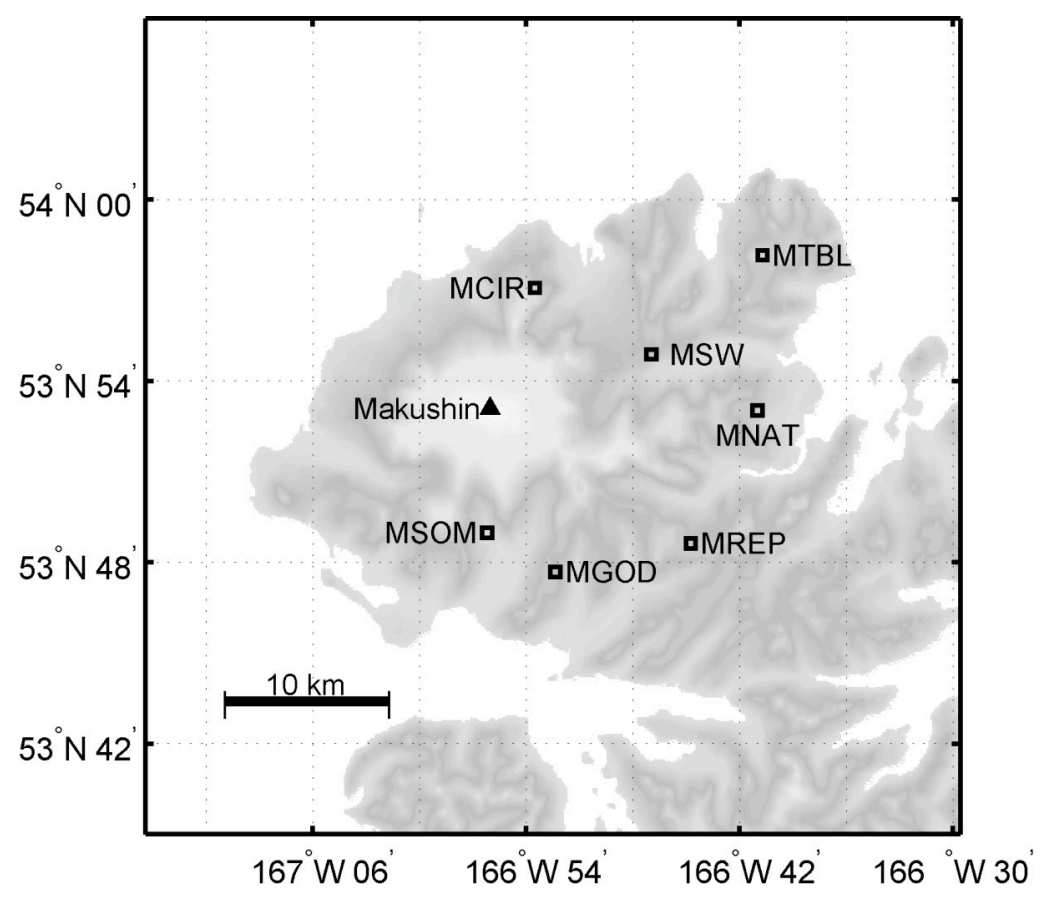

Figure C18. AVO seismograph stations near Makushin Volcano. Seismograph stations are shown by open squares. Closed triangles show volcanic centers. 


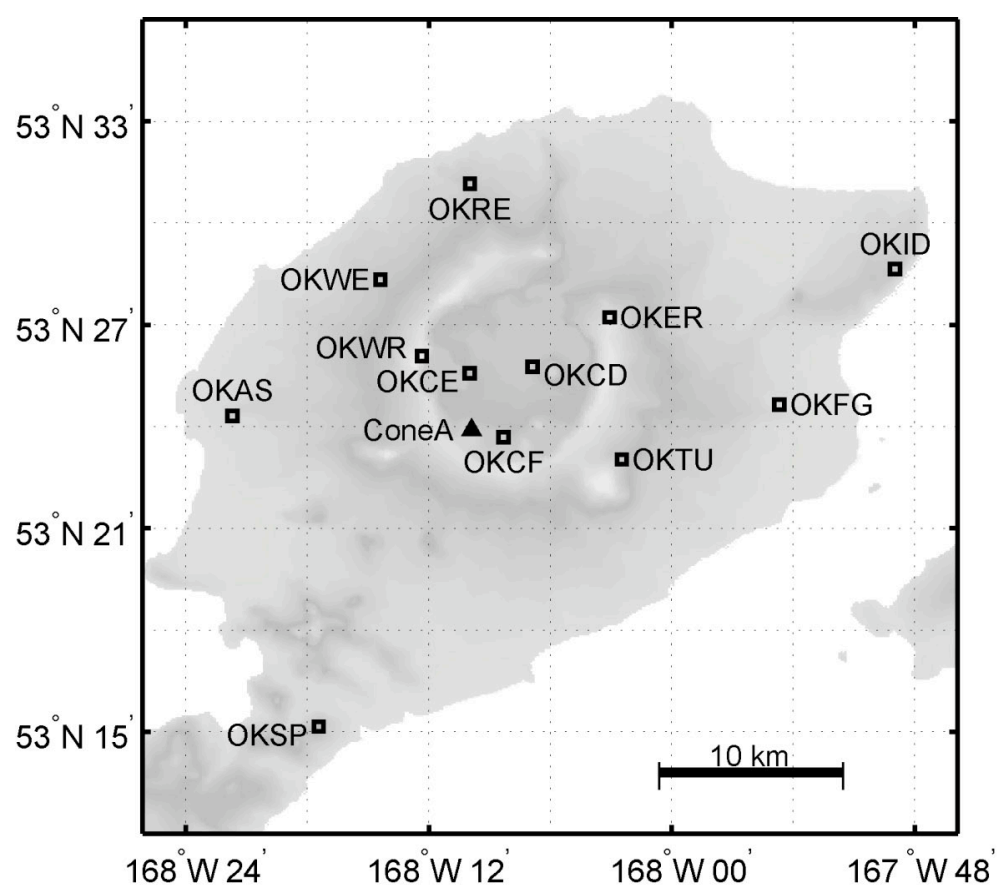

Figure C19. AVO seismograph stations near Okmok Volcano. Seismograph stations are shown by open squares. Closed triangles show volcanic centers.

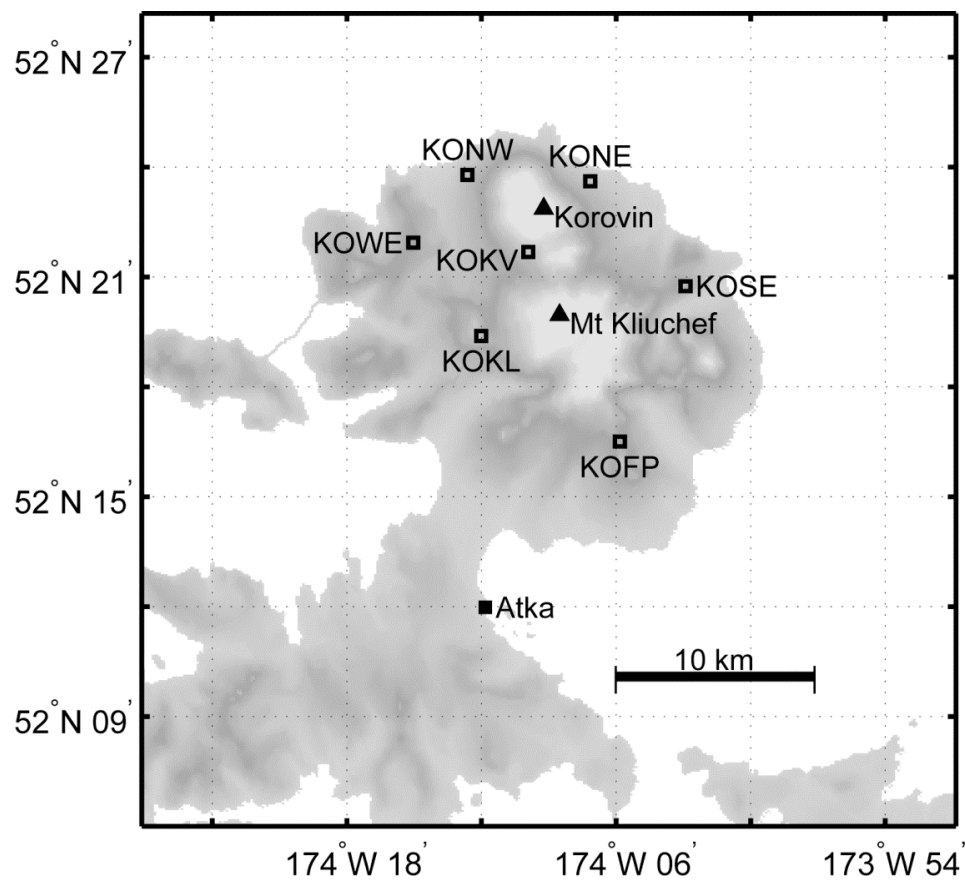

Figure C20. AVO seismograph stations near Korovin Volcano. Seismograph stations are shown by open squares. Closed triangles show volcanic centers. 


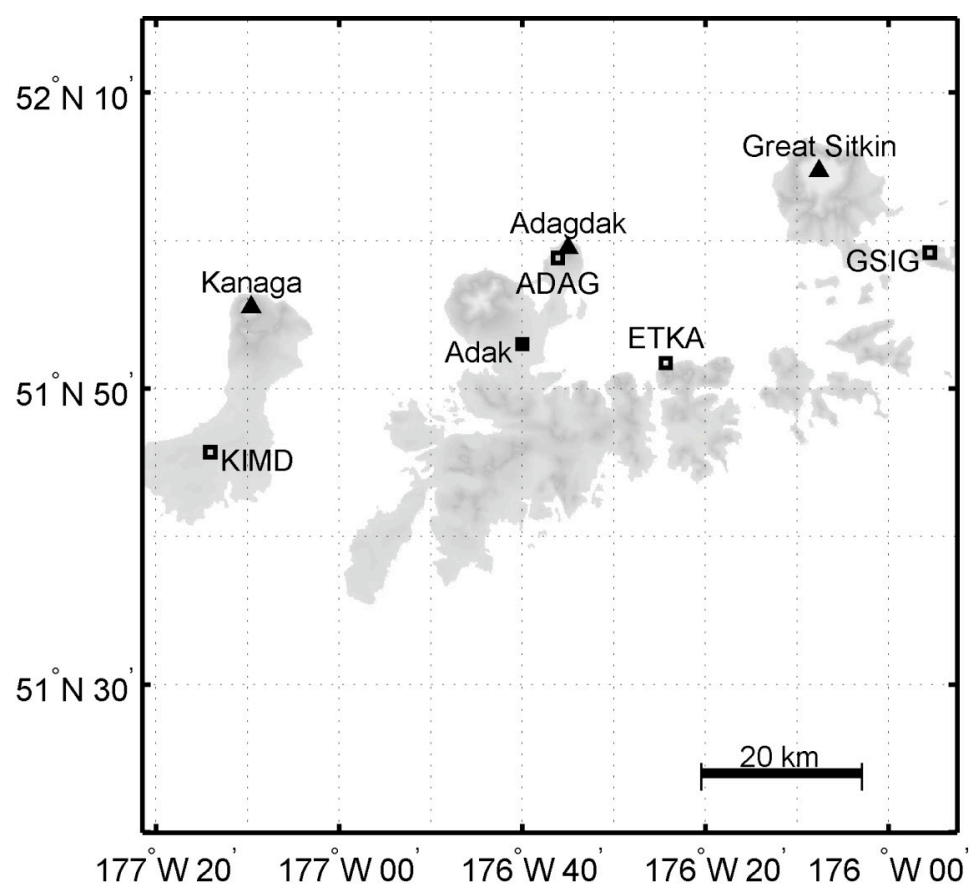

Figure C21. Regional AVO seismograph stations around Adak Island. Seismograph stations are shown by open squares. Closed triangles show volcanic centers.

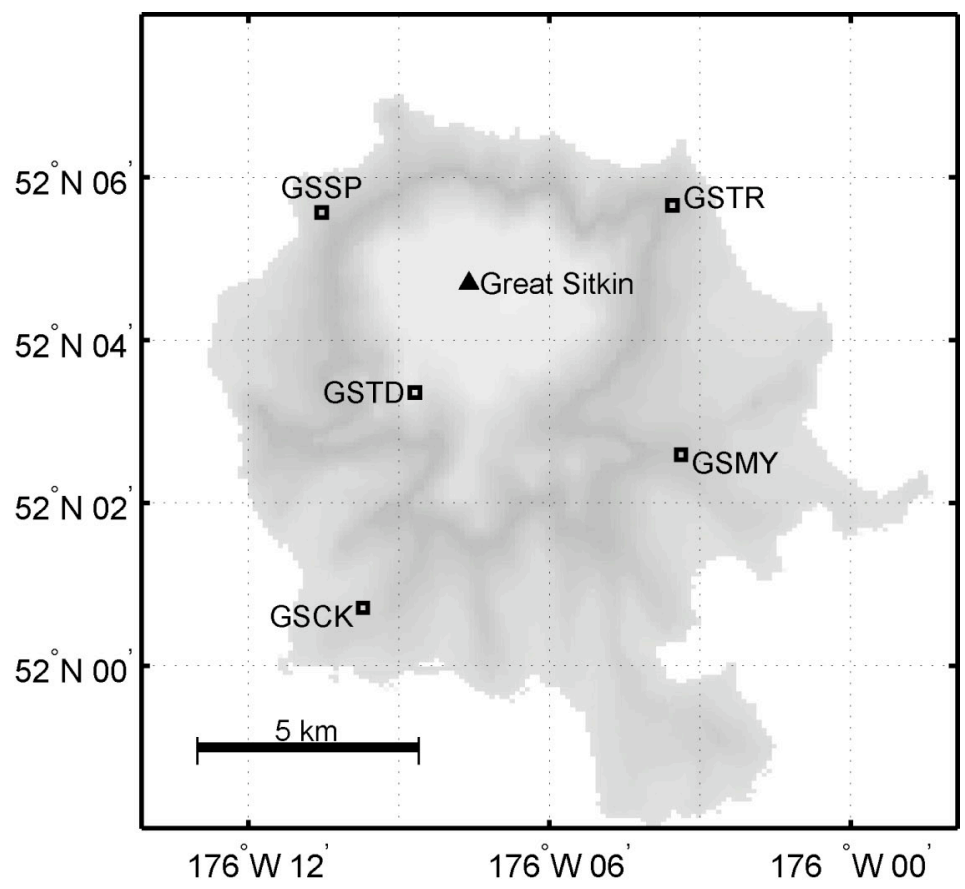

Figure C22. AVO seismograph stations near Great Sitkin Volcano. Seismograph stations are shown by open squares. Closed triangles show volcanic centers. 


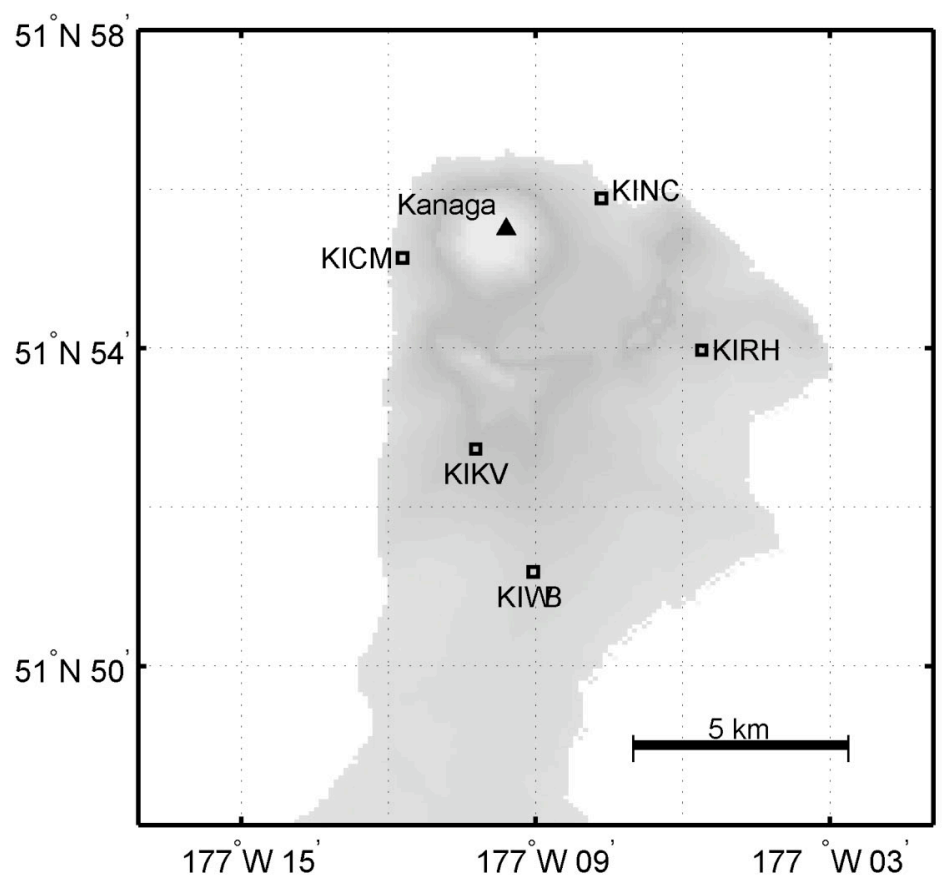

Figure C23. AVO seismograph stations near Kanaga Volcano. Seismograph stations are shown by open squares. Closed triangles show volcanic centers.

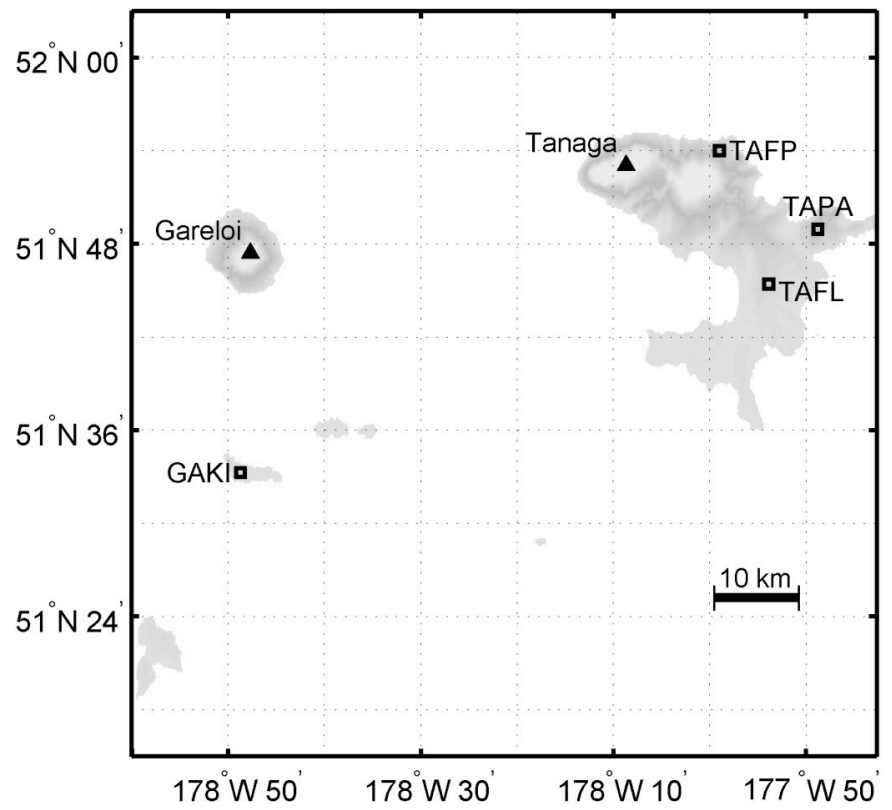

Figure C24. Regional AVO seismograph stations around Tanaga Volcano and Mount Gareloi. Seismograph stations are shown by open squares. Closed triangles show volcanic centers. 


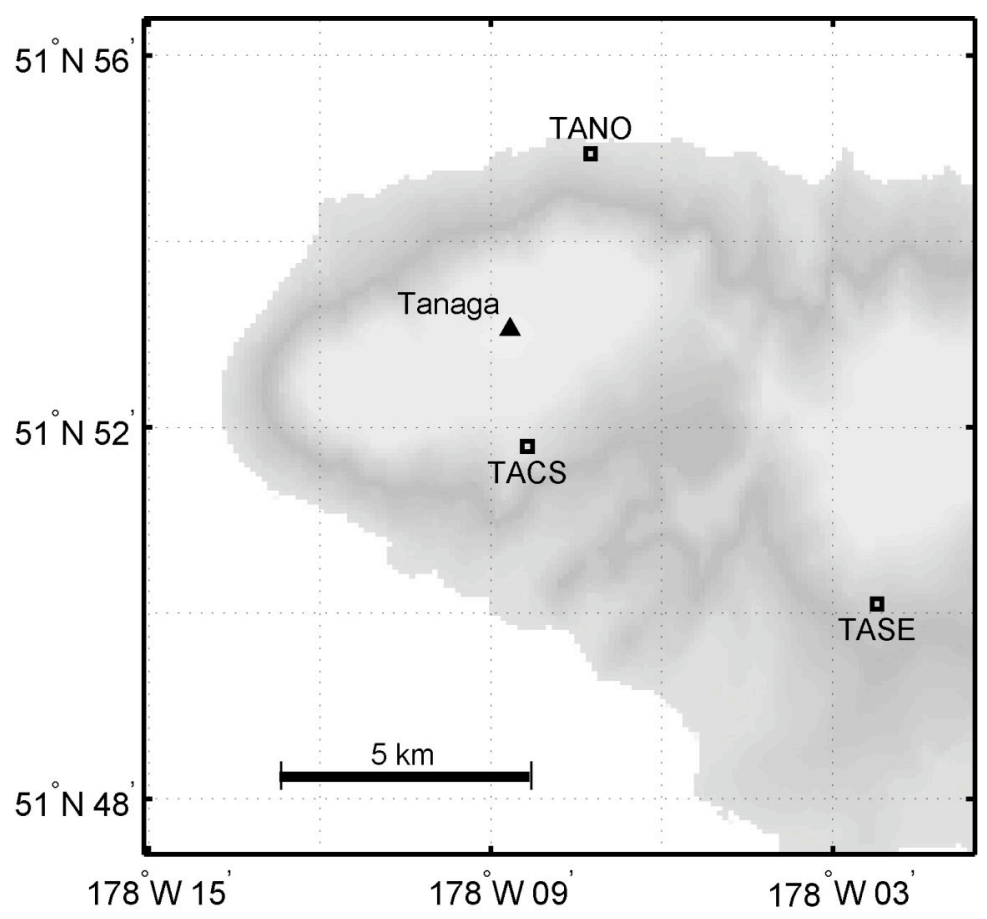

Figure C25. AVO seismograph stations near Tanaga Volcano. Seismograph stations are shown by open squares. Closed triangles show volcanic centers.

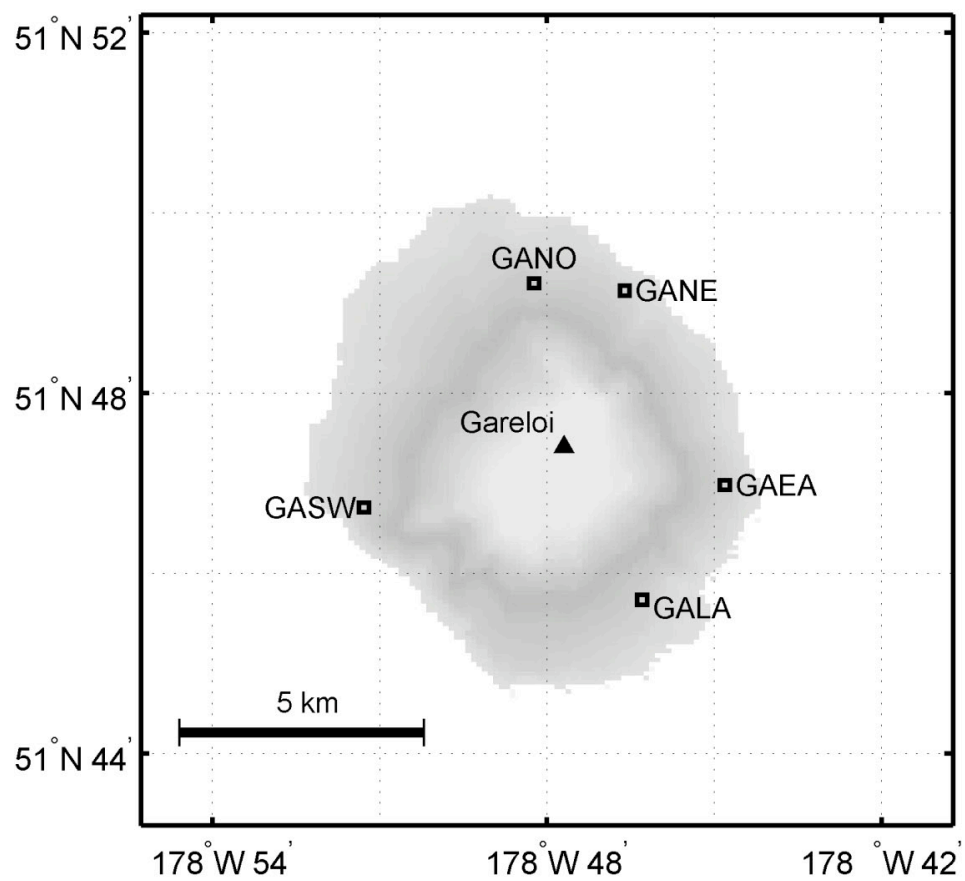

Figure C26. AVO seismograph stations near Mount Gareloi. Seismograph stations are shown by open squares. Closed triangles show volcanic centers. 
Appendix D: Estimate of operational status for all AVO stations. A solid bar indicates periods of time a station was operational based on daily station use plots and weekly operational checks.

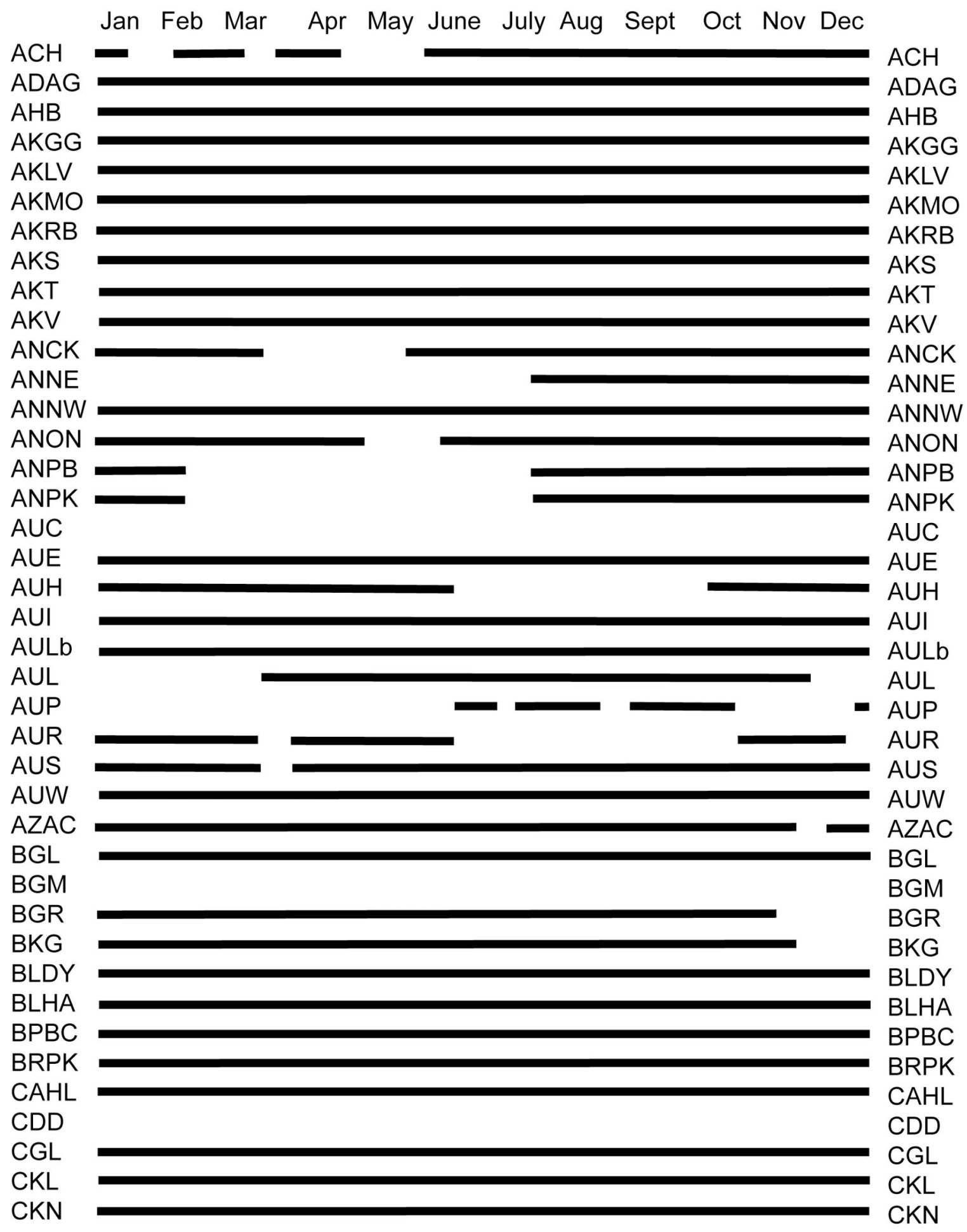




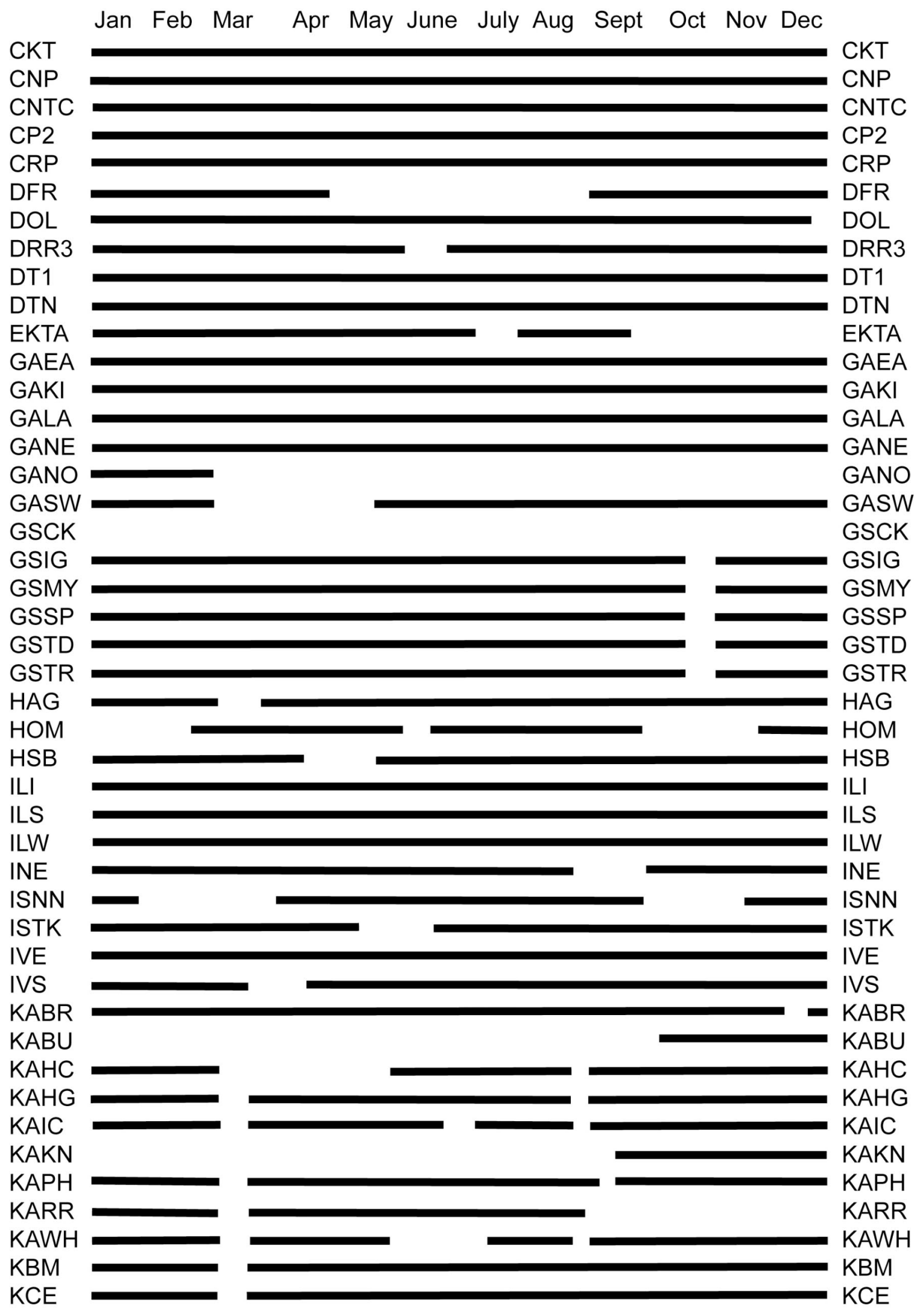




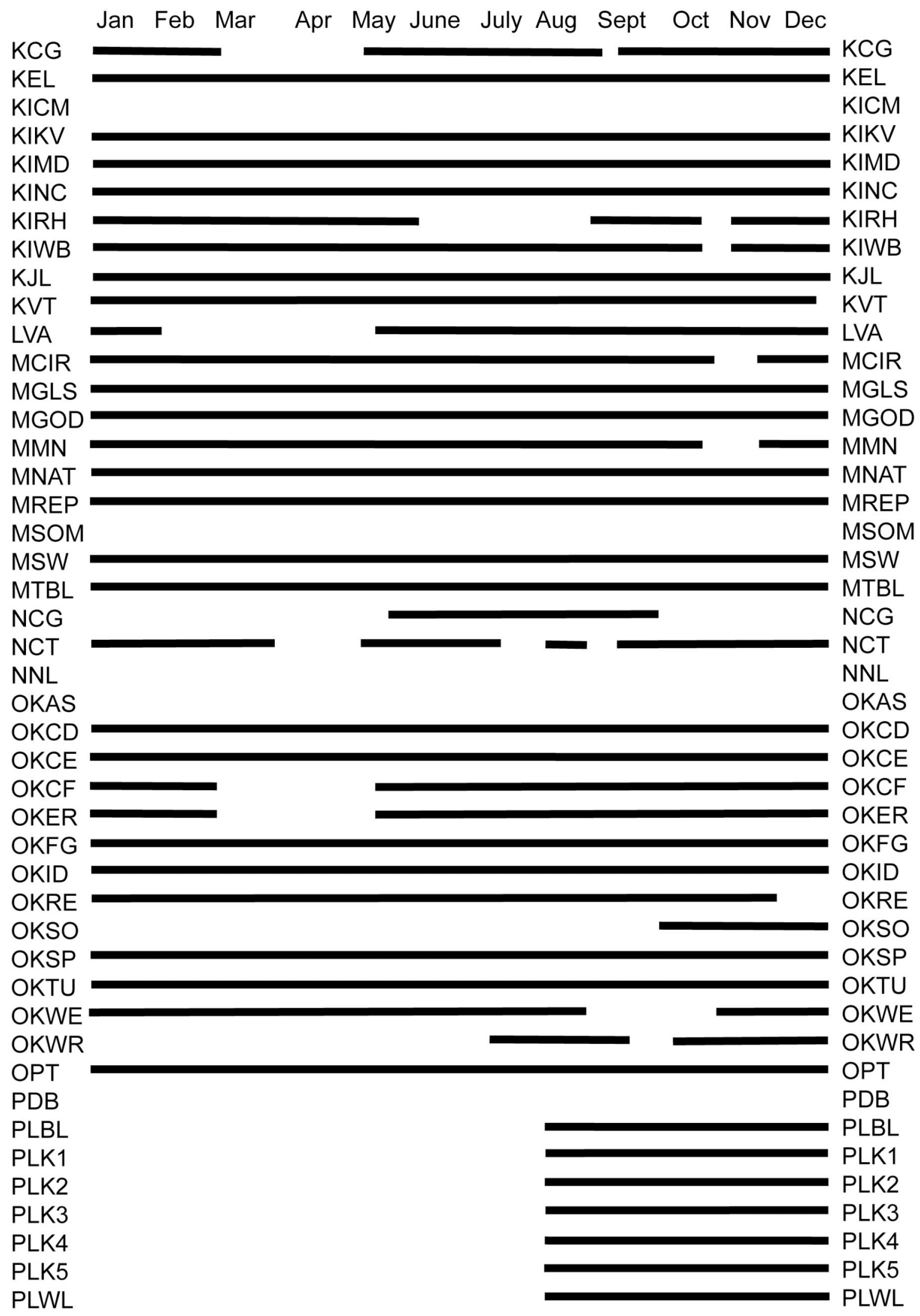




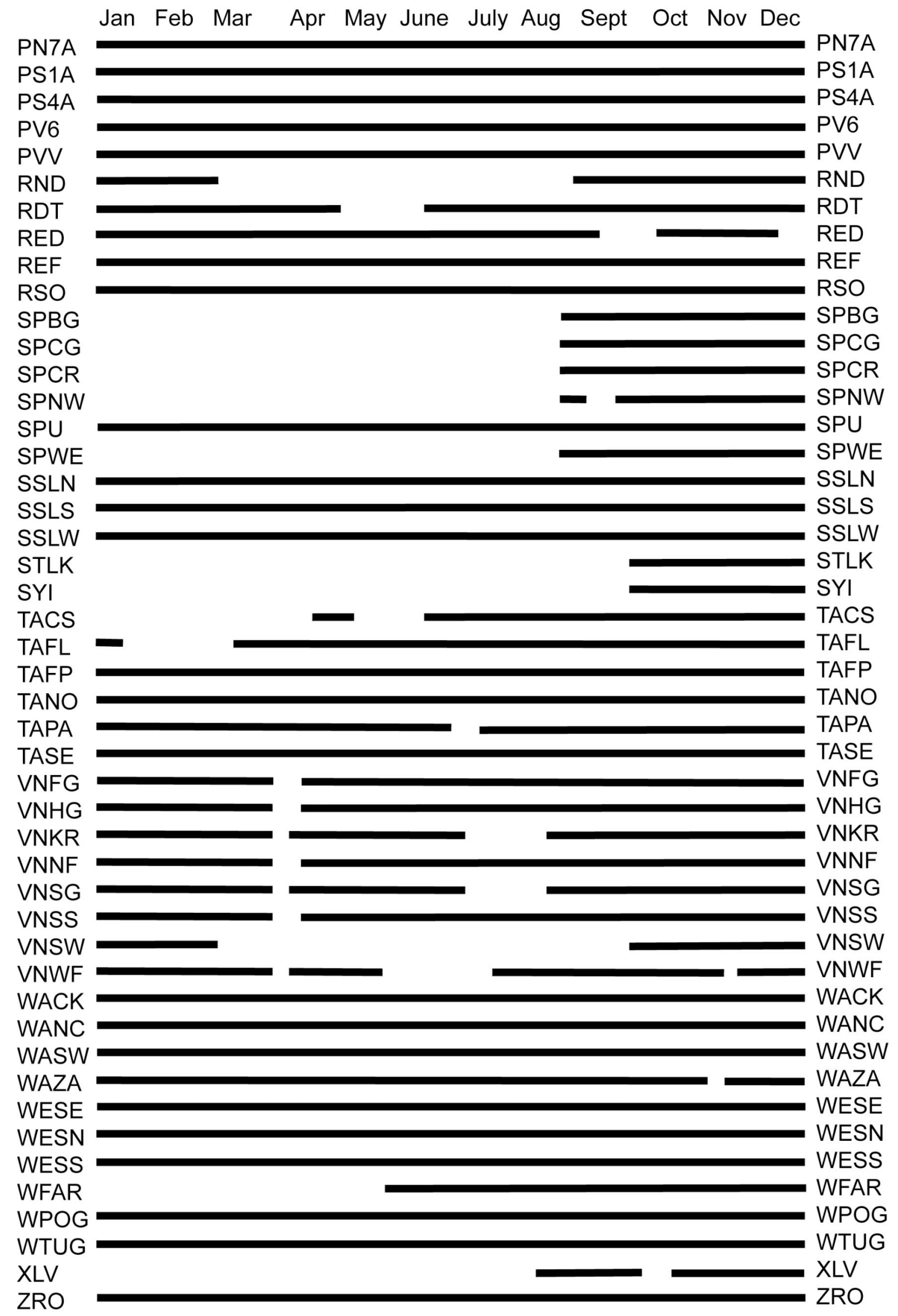


Appendix E: Velocity models used in locating the earthquakes described in this report. Following the name of each velocity model is a list of monitored volcanoes for which the model is used. Depths are referenced to sea level, with negative values reflecting height above sea level.

\begin{tabular}{|c|c|c|c|c|c|}
\hline \multicolumn{6}{|c|}{ Cylindrical Model Parameters } \\
\hline Velocity Model & Latitude $\left({ }^{\circ} \mathrm{N}\right)$ & Longitude $\left({ }^{\circ} \mathrm{W}\right)$ & $\underline{\text { Radius }(\mathrm{km})}$ & $\underline{\text { Top }(\mathrm{km})}$ & Bottom $(\mathrm{km})$ \\
\hline Spurr & 61.60 & 152.40 & 20 & -3 & 50 \\
\hline Spurr & 61.47 & 152.33 & 20 & -3 & 50 \\
\hline Spurr & 61.33 & 152.25 & 20 & -3 & 50 \\
\hline Spurr & 61.17 & 152.35 & 20 & -3 & 50 \\
\hline Spurr & 61.00 & 152.45 & 20 & -3 & 50 \\
\hline Redoubt & 60.83 & 152.55 & 20 & -3 & 50 \\
\hline Redoubt & 60.66 & 152.66 & 20 & -3 & 50 \\
\hline Redoubt & 60.49 & 152.75 & 20 & -3 & 50 \\
\hline Redoubt & 60.34 & 152.86 & 20 & -3 & 50 \\
\hline Redoubt & 60.19 & 152.98 & 20 & -3 & 50 \\
\hline Redoubt & 59.87 & 153.17 & 20 & -3 & 50 \\
\hline Redoubt & 59.70 & 153.25 & 20 & -3 & 50 \\
\hline Redoubt & 59.53 & 153.34 & 20 & -3 & 50 \\
\hline Iliamna & 60.03 & 153.09 & 20 & -3 & 50 \\
\hline Augustine & 59.36 & 153.42 & 20 & -3 & 50 \\
\hline Katmai & 58.17 & 155.35 & 20 & -3 & 50 \\
\hline Katmai & 58.29 & 154.86 & 20 & -3 & 50 \\
\hline Katmai & 58.35 & 155.09 & 20 & -3 & 50 \\
\hline Katmai & 58.43 & 154.38 & 20 & -3 & 50 \\
\hline Cold Bay & 55.42 & 161.89 & 20 & -3 & 50 \\
\hline Cold Bay & 55.18 & 162.27 & 20 & -3 & 50 \\
\hline Cold Bay & 54.76 & 163.97 & 30 & -3 & 50 \\
\hline Cold Bay & 54.52 & 164.65 & 20 & -3 & 50 \\
\hline Akutan & 54.15 & 165.97 & 20 & -3 & 50 \\
\hline Andreanof & 52.08 & 176.13 & 20 & -3 & 50 \\
\hline Andreanof & 51.93 & 176.75 & 20 & -3 & 50 \\
\hline Andreanof & 51.92 & 177.17 & 20 & -3 & 50 \\
\hline
\end{tabular}

Regional Velocity Model (for all areas south of $62.5^{\circ} \mathrm{N}$ not covered by a volcano specific model): Aniakchak Crater, Mount Gareloi, Korovin Volcano, Makushin Volcano, Okmok Volcano, Mount Peulik, Tanaga Volcano, Mount Veniaminof, and Mount Wrangell (Fogleman and others, 1993).

\begin{tabular}{cccc} 
Layer number & $\mathrm{Vp}(\mathrm{km} / \mathrm{sec})$ & Top of layer $(\mathrm{km})$ & $\underline{\mathrm{Vp} / \mathrm{Vs}}$ \\
\hline 1 & 5.3 & -3.0 & 1.78 \\
2 & 5.6 & 4.0 & 1.78 \\
3 & 6.2 & 10.0 & 1.78 \\
4 & 6.9 & 15.0 & 1.78 \\
5 & 7.4 & 20.0 & 1.78 \\
6 & 7.7 & 25.0 & 1.78 \\
7 & 7.9 & 33.0 & 1.78 \\
8 & 8.1 & 47.0 & 1.78 \\
9 & 8.3 & 65.0 & 1.78
\end{tabular}


Akutan Velocity Model: Akutan Peak (Power and others, 1996).

Layer number

$1 \quad 2.30+0.37 \mathrm{~km} / \mathrm{sec}$ for each $\mathrm{km}$ of depth

2
6.30
Top of layer $(\mathrm{km})$

-3.0
7.0
$\frac{\mathrm{Vp} / \mathrm{Vs}}{1.80}$

1.80

Andreanof Velocity model: Great Sitkin Volcano, Kanaga Volcano (Toth and Kisslinger, 1984).

\section{Layer number}

1
2
3
4
5
6
7
8
9
10
11
12
13
14
15
16
17
18
19
20

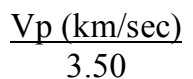

3.88

4.25

4.62

5.00

5.50

5.62

5.74

5.86

5.98

6.10

6.60

6.68

6.80

6.92

7.04

7.16

7.28

7.85

8.05
Top of layer $(\mathrm{km})$

$-3.0$

$-2.8$

$-2.6$

$-2.4$

$-2.2$

$-2.0$

$-1.0$

0.0

1.0

2.0

3.0

4.0

5.0

8.0

11.0

14.0

17.0

20.0

23.0

37.0
$\mathrm{Vp} / \mathrm{Vs}$

1.73

1.73

1.73

1.73

1.73

1.73

1.73

1.73

1.73

1.73

1.73

1.73

1.73

1.73

1.73

1.73

1.73

1.73

1.73

1.73

Augustine Velocity Model: Augustine Volcano (Power, 1988).

\begin{tabular}{c} 
Layer number \\
\hline 1 \\
2 \\
3 \\
4 \\
5 \\
6
\end{tabular}

\begin{tabular}{c}
$\mathrm{Vp}(\mathrm{km} / \mathrm{sec})$ \\
\hline 2.3 \\
2.6 \\
3.4 \\
5.1 \\
6.3 \\
8.0
\end{tabular}

\begin{tabular}{c} 
Top of layer $(\mathrm{km})$ \\
\hline-3.0 \\
-0.7 \\
0.0 \\
1.0 \\
9.0 \\
44.0
\end{tabular}

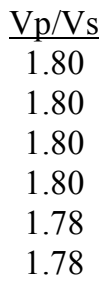

Cold Bay Velocity Model: Mount Dutton, Fisher Caldera, Isanotski Peaks, Pavlof Volcano, Shishaldin Volcano and Westdahl Peak (McNutt and Jacob, 1986).

$\underline{\text { Layer number }}$

1
2
3
4
5
6
7

$\underline{\mathrm{Vp}(\mathrm{km} / \mathrm{sec})}$

3.05

3.44

5.56

6.06

6.72

7.61

7.90
Top of layer $(\mathrm{km})$

$-3.00$

0.00

1.79

3.65

10.18

22.63

38.51

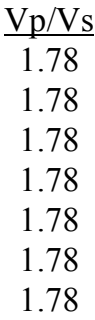


Iliamna Velocity model: Iliamna Volcano (Roman and others, 2001).

\begin{tabular}{c} 
Layer number \\
\hline 1 \\
2 \\
3 \\
4 \\
5 \\
6
\end{tabular}

\begin{tabular}{c}
$\mathrm{Vp}(\mathrm{km} / \mathrm{sec})$ \\
\hline 4.8 \\
6.1 \\
6.2 \\
6.3 \\
6.4 \\
7.1
\end{tabular}

Top of layer $(\mathrm{km})$

\begin{tabular}{c}
$\mathrm{Vp} / \mathrm{Vs}$ \\
\hline 1.78 \\
1.78 \\
1.78 \\
1.78 \\
1.78 \\
1.78
\end{tabular}

Katmai Velocity Model: Mount Griggs, Mount Katmai, Mount Mageik, Mount Martin, Novarupta, Snowy Mountain, and Trident Volcano (Searcy, 2003).

\begin{tabular}{cccc} 
Layer number & $\mathrm{Vp}(\mathrm{km} / \mathrm{sec})$ & Top of layer $(\mathrm{km})$ & $\underline{\mathrm{Vp} / \mathrm{Vs}}$ \\
\cline { 2 - 4 } 1 & 5.05 & -3.0 & 1.78 \\
2 & 5.10 & 1.0 & 1.78 \\
3 & 5.41 & 2.0 & 1.78 \\
4 & 5.49 & 3.0 & 1.78 \\
5 & 5.65 & 4.0 & 1.78 \\
6 & 5.67 & 5.0 & 1.78 \\
7 & 5.69 & 6.0 & 1.78 \\
8 & 5.76 & 7.0 & 1.78 \\
9 & 5.80 & 8.0 & 1.78 \\
10 & 6.00 & 9.0 & 1.78 \\
11 & 6.04 & 10.0 & 1.78 \\
12 & 6.08 & 12.0 & 1.78 \\
13 & 6.30 & 15.0 & 1.78 \\
14 & 6.73 & 20.0 & 1.78 \\
15 & 7.54 & 25.0 & 1.78 \\
16 & 7.78 & 33.0 & 1.78
\end{tabular}

Redoubt Velocity Model: Redoubt Volcano (Lahr and others, 1994) .

Layer number

1
2
3
4

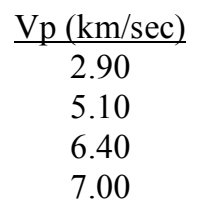

Top of layer $(\mathrm{km})$
-3.0
-1.7
1.5
17.0

Spurr Velocity Model: Mount Spurr (Jolly and others, 1994).

\begin{tabular}{cccc} 
Layer number & Vp $(\mathrm{km} / \mathrm{sec})$ & $\frac{\text { Top of layer }(\mathrm{km})}{\mathrm{Vp} / \mathrm{Vs}}$ & 1.81 \\
\cline { 2 - 4 } & 5.1 & -3.00 & 1.81 \\
2 & 5.5 & -2.00 & 1.74 \\
3 & 6.3 & 5.25 & 1.78
\end{tabular}




\section{Appendix F: Maps showing the location of the volcanic zones modeled using cylinders described in Appendix E.}

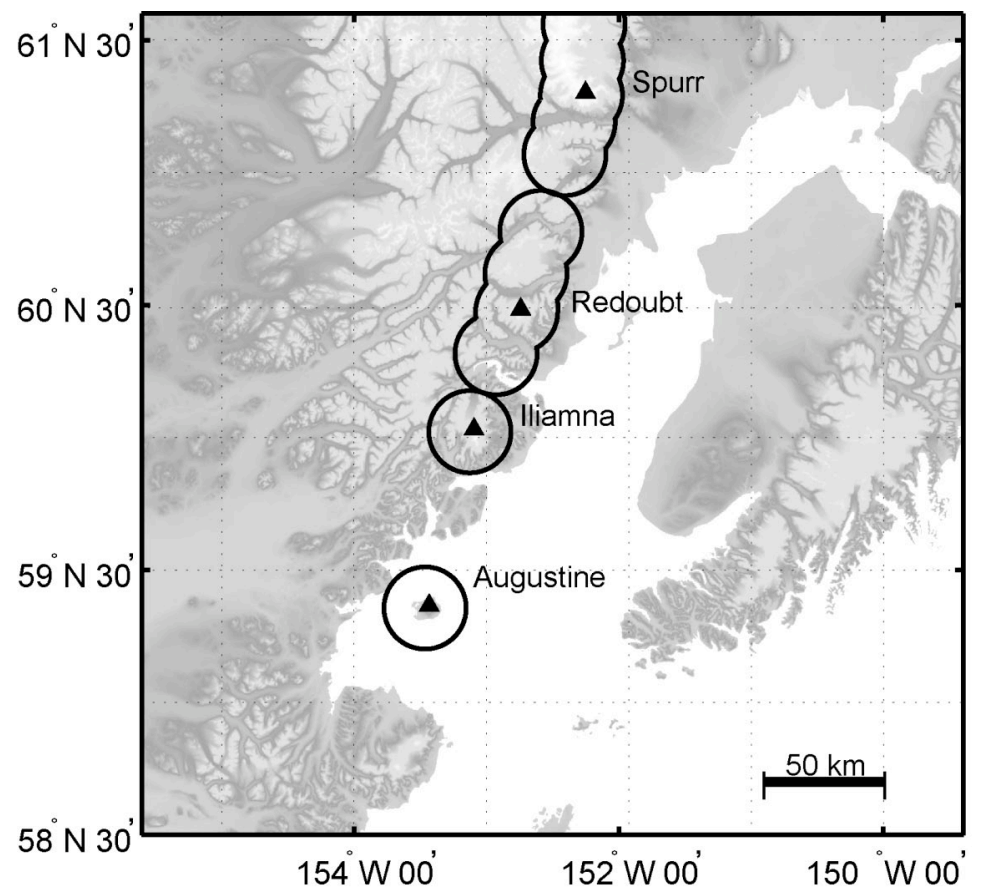

Figure F1. Volcanic zones for the Cook Inlet Volcanoes. Five overlapping cylinders model the Spurr volcanic zone. Four overlapping cylinders model the Redoubt volcanic zone. Single cylinders model the Iliamna and Augustine volcanic zones.

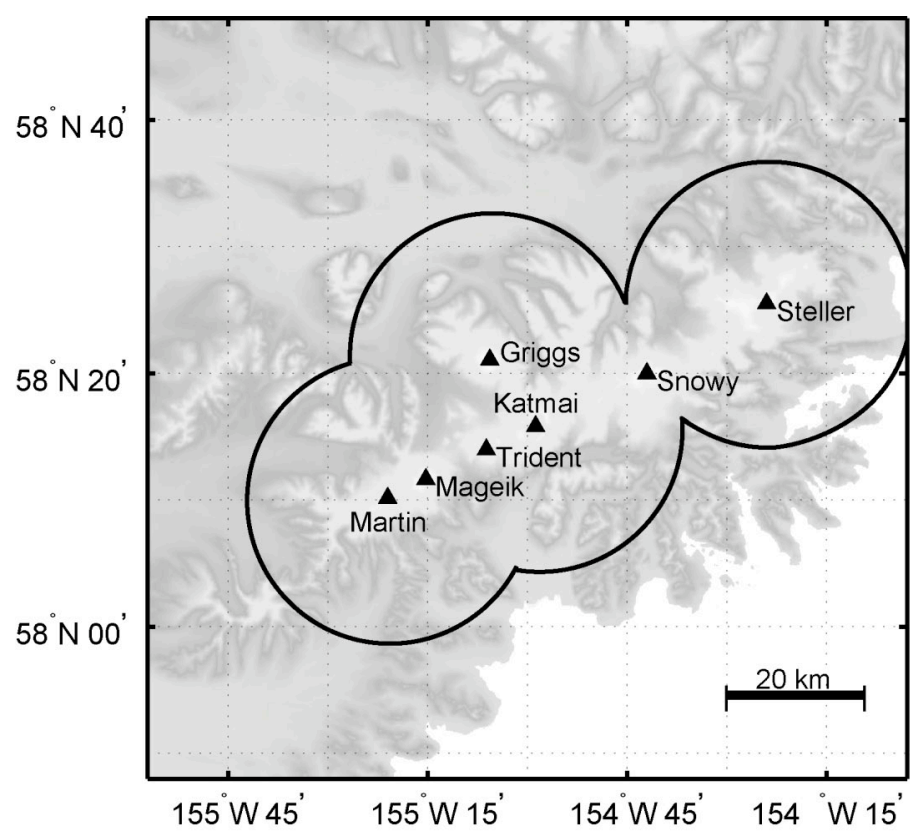

Figure F2. Volcanic zone for the Katmai volcanic cluster. The volcanic zone is modeled using four cylinders centered on Mount Martin, Mount Katmai, Mount Griggs and Mount Steller. 


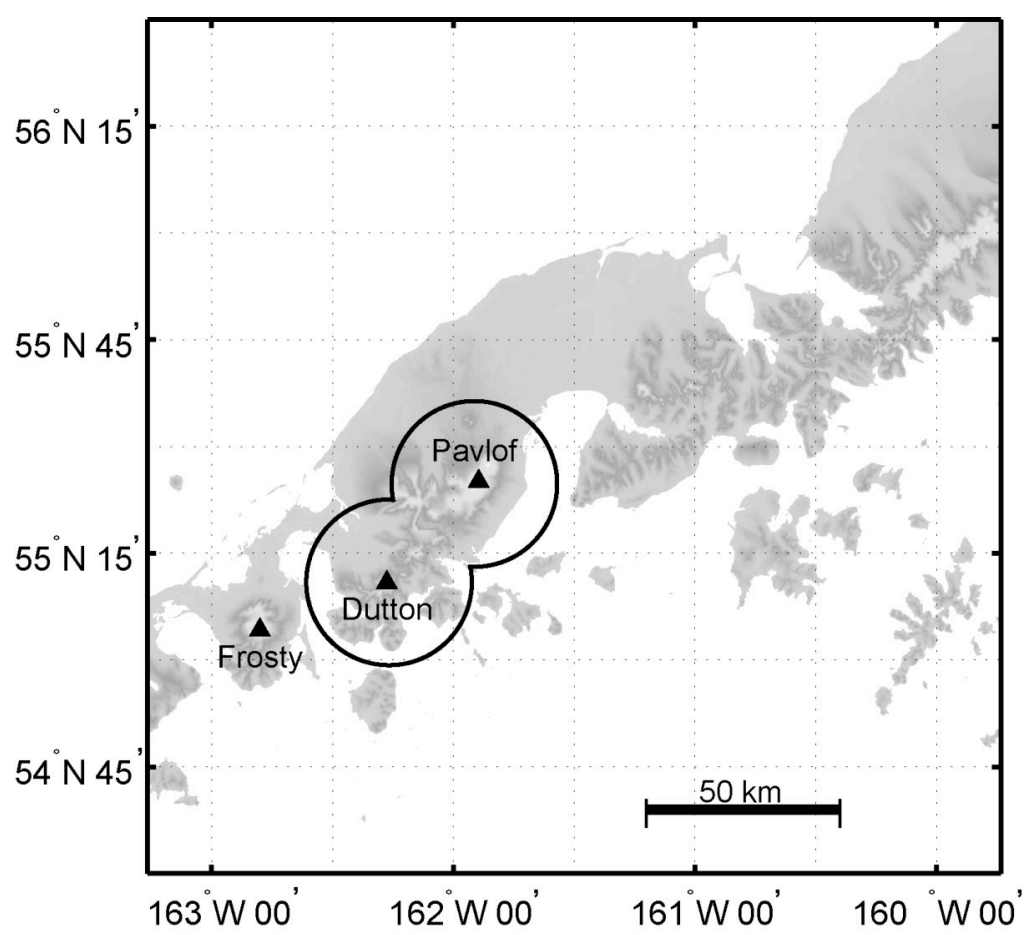

Figure F3. Volcanic zones for Pavlof Volcano and Mount Dutton. The volcanic zone is modeled using two cylinders centered on Mount Dutton and Pavlof Volcano.

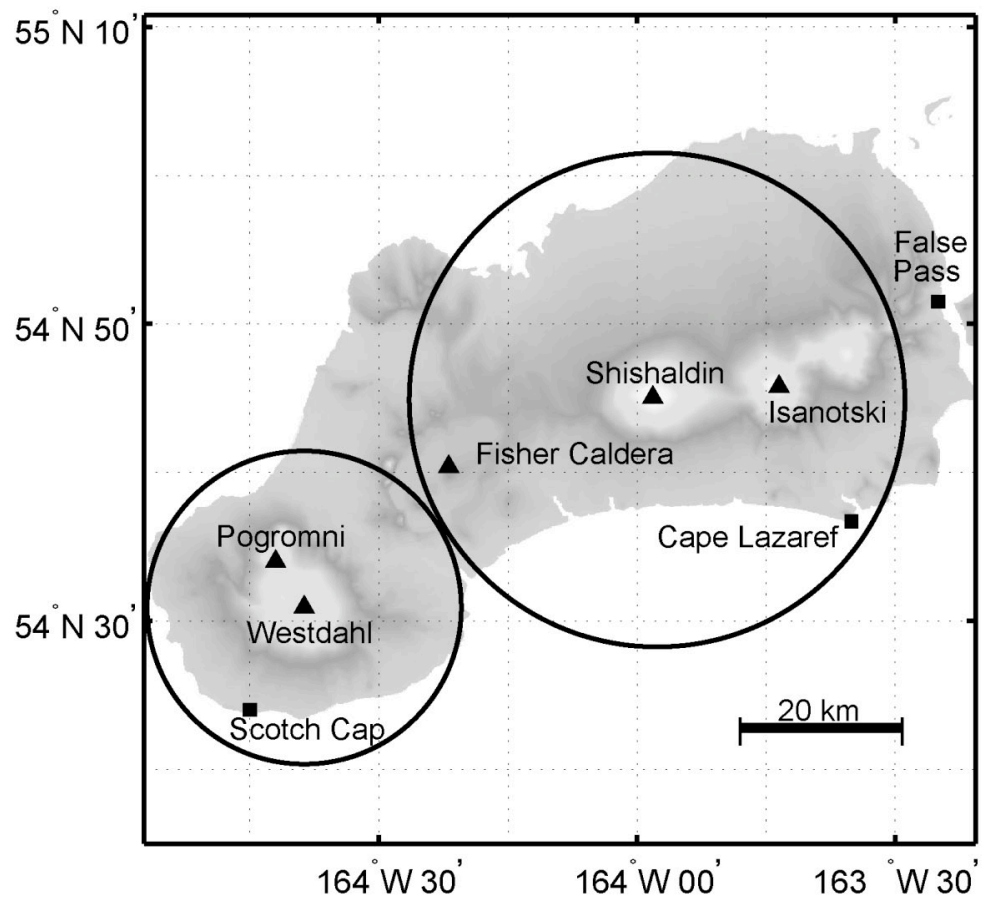

Figure F4. Volcanic zones on Unimak Island. The volcanic zones are modeled using a cylinder centered on Westdahl Peak and a cylinder centered on Shishaldin Volcano. 


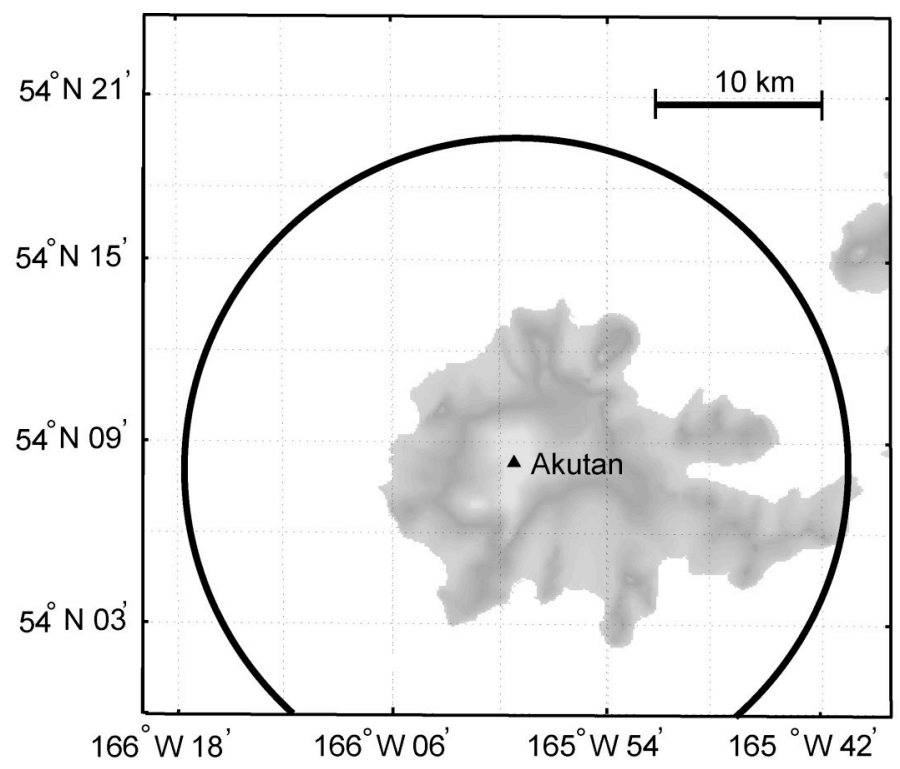

Figure F5. Volcanic zone for Akutan Volcano. The volcanic zone is modeled using a single cylinder.

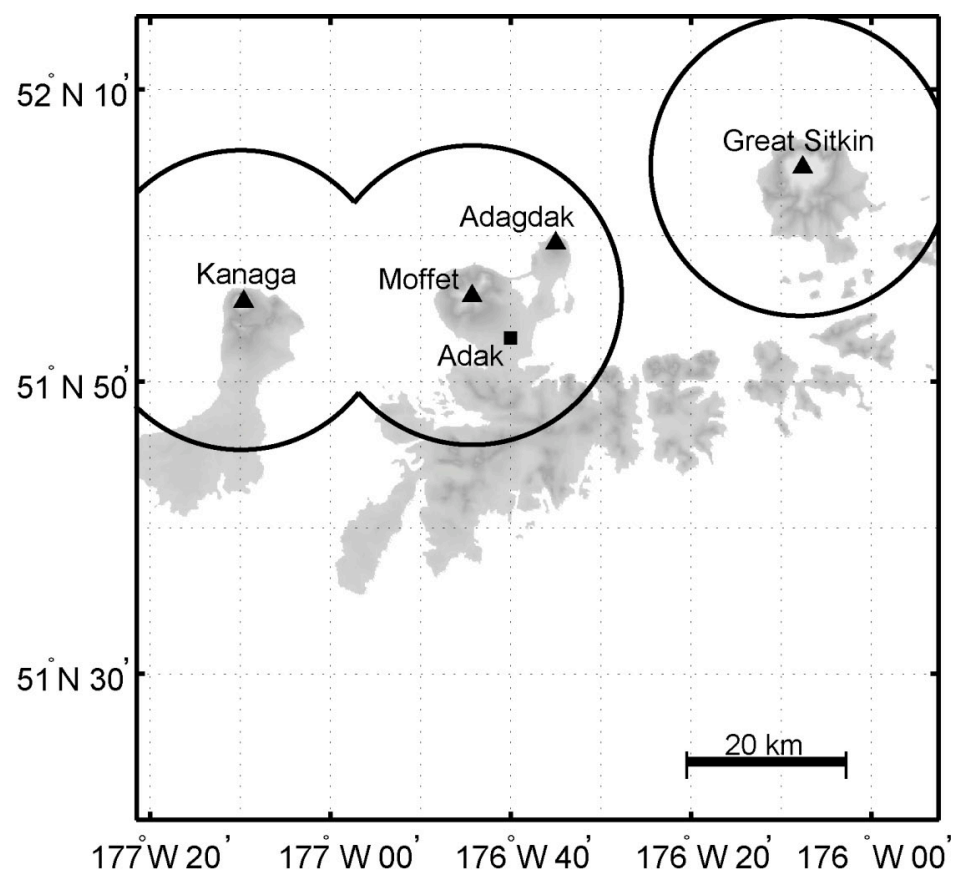

Figure F6. Volcanic zones in the Adak region. The volcanic zones are modeled using cylinders centered on Kanaga Volcano, Mount Moffet, and Great Sitkin Volcano. 


\section{Appendix G: Selected AVO papers published in 2004}

Caplan-Auerbach, J., Moran, S.C., Tytgat, G., Plucinski, T.A., McNutt, S.R., and Paskievitch, J.F., 2004, Seismic Explorations in the Eastern Aleutians, Alaska, Seismological Research Letters, v.75, p. 8-21.

McNutt, S.R., and Marzocchi, W., 2004, Simultaneous earthquake swarms and eruption in Alaska, Fall 1996: Statistical Significance and Inference of a Large Aseismic Slip Event, Bulletin of the Seismological Society of America, v.94, p. 1831-1841.

Moran, S.C., Power, J.A., Stihler, S.D., Sánchez, J.J., and Caplan-Auerbach, J., 2004, Earthquake triggering at Alaskan volcanoes following the November3, 2002 Denali Fault Earthquake, Bulletin of the Seismological Society of America, v.94, p. 5300-5309.

Power, J.A., Stihler, S.D., White, R.A., Moran, S.C., 2004, Observations of deep longperiod (DLP) seismic events beneath Aleutian arc volcanoes: 1989 - 2002, Journal of Volcanology and Geothermal Research, v. 138, p. 243 - 266.

Power, J.A., 2004, Renewed unrest at Mount Spurr Volcano, Alaska, EOS, v. 85, \#43, p. 434.

Roman, D.C., Moran, S.C., Power, J.A., Cashman, K.V., 2004, Temporal and spatial variation of local stress fields during the 1992 eruption of Crater Peak vent, Mount Spurr, Alaska, Bulletin of Seismological Society of America, v. 94, p. 2366 - 2379.

Sánchez, J.J., Wyss, M., and McNutt, S.R., 2004, Temporal-spatial variations in stress at Redoubt volcano, Alaska, inferred from inversion of fault plane solutions. Journal of Volcanology and Geothermal Research, v. 130, p. 1-30.

Sánchez, J.J., McNutt, S.R., Power, J.A., and Wyss, M., 2004. Spatial variations in the frequency-magnitude distribution of earthquakes at Mount Pinatubo volcano. Bulletin of the Seismological Society of America, v. 94, p. 430-438.

Sánchez, J.J., and McNutt, S.R., 2004, Intermediate-term declines in seismicity at Mt. Wrangell and Mt. Veniaminof volcanoes, Alaska, following the 3 November 2002 Mw 7.9 Denali Fault Earthquake. Bulletin of the Seismological Society of America, v. 94, p. S370-S383.

Sánchez, J.J., and McNutt, S.R., 2004, Unexpected response of Mt. Wrangell Volcano, Alaska, to the shaking from a large regional earthquake: A puzzle for intermediate-term earthquake-volcanoes interactions. Earth Sciences Research Journal, v 8, p. 34-44. 